\title{
VARIABILITY IN TRAFFIC MONITORING DATA FINAL SUMMARY REPORT
}

\section{Tommy Wright* \\ and \\ Patricia S. Hu}

Center for Transportation Analysis

of

Oak Ridge National Laboratory

Oak Ridge, Tennessee 37831-6073

and

Jennifer Young

and

An Lu

of

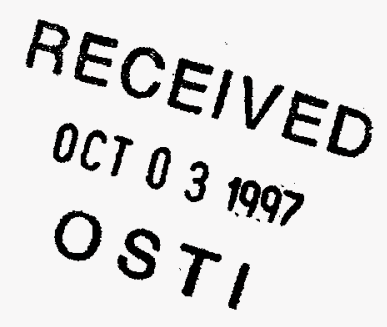

University of Tennessee-Knoxville

Knoxville, Tennessee 37831

${ }^{*}$ Currently with the U. S. Census Bureau

Revised August 1997

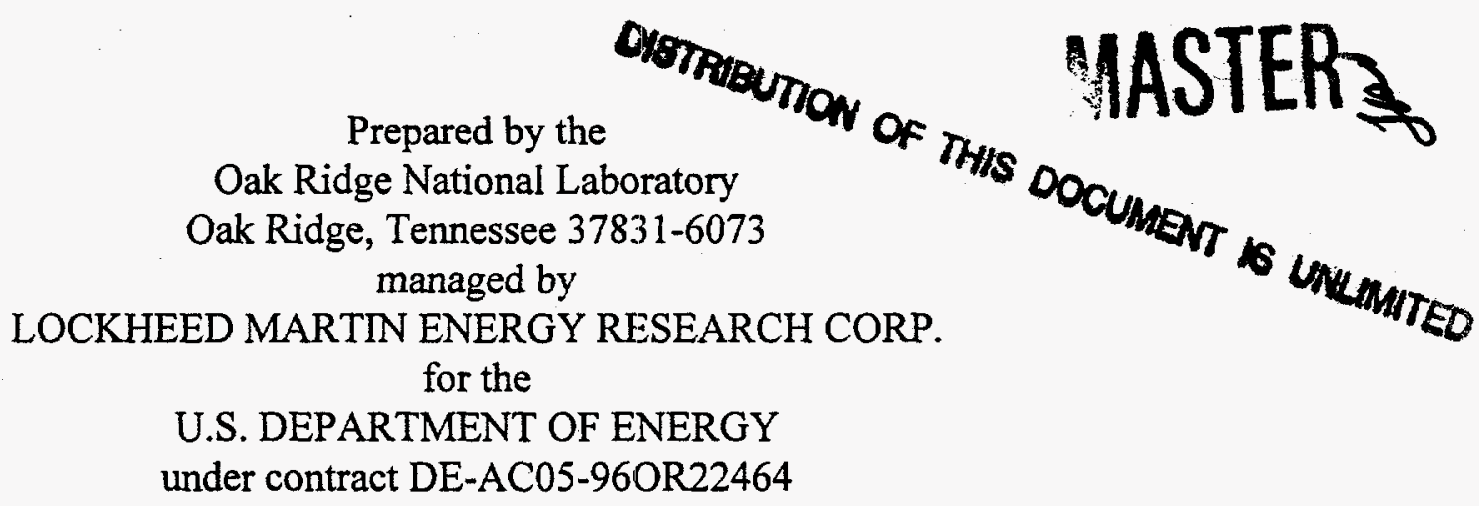




\section{DISCLAIMER}

This report was prepared as an account of work sponsored by an agency of the United States Government. Neither the United States Government nor any agency thereof, nor any of their employees, makes any warranty, express or implied, or assumes any legal liability or responsibility for the accuracy, completeness, or usefulness of any information, apparatus, product, or process disclosed, or represents that its use would not infringe privately owned rights. Reference herein to any specific commercial product, process, or service by trade narne, trademark, manufacturer, or otherwise does not necessarily constitute or imply its endorsement, recommendation, or favoring by the United States Government or any agency thereof. The views and opinions of authors expressed herein do not necessarily state or reflect those of the United States Government or any agency thereof. 


\section{DISCLAIMER}

Portions of this document may be illegible electronic image products. Images are produced from the best available original document. 


\section{ACKNOWLEDGMENTS}

This report summarizes research results reported in five earlier reports in this series [2], [3], [4], [7], and [16]. The research was sponsored by the Federal Highway Administration (FHWA). We are especially grateful to Tony Esteve (FHWA) for his guidance and many valuable suggestions following an earlier draft of this report as well as earlier reports. Many of these comments and suggestions have found their way into this report.

We are also grateful to Bruce Gordon, Harshad Desai, Rick Reel and Ronnie Price of the Florida Department of Transportation and Calvin Smith, Debbie Daugherty, Mark Finch, and Irene Hertwig of the Washington Department of Transportation for providing constructive criticism and their state traffic monitoring data for 1994. We used the SAS software to produce all tables. With the exception of a few consistency checks, we did no editing of the data received.

Finally, the expert secretarial assistance of Rene' Moskol, CPS, is gratefully appreciated. 


\section{NOTICE}

The contents of this report reflect the views of the authors, who are responsible for the accuracy of the results presented herein. The contents do not necessarily reflect the official policy of the Federal Highway Administration, U. S. Department of Transportation.

The report does not constitute a standard, specification, or regulation. 


\section{EXECUTIVE SUMMARY}

For highway maintenance and planning purposes, it is desirable to characterize each road segment by its traffic flow [such as the annual average daily traffic (AADT) and the AADT for each vehicle class], by the weight distribution of vehicles that travel on its roads [such as the annual average daily equivalent single axle loadings (ESAL) and the annual average daily weight per vehicle for each vehicle class].

If there were no budget constraints, then each road segment could be continuously monitored every day of the year to determine the values of the aforementioned traffic characteristics. However, in practice, a few road segments are monitored continuously every day of the year to produce annual characteristics of traffic flow. A sample of the remaining road segments are monitored for one or two days each year. These road segments are called the short-term monitored sites. Data collected from the short-term monitored sites are then "adjusted" (using factors based on data collected from the continuously monitored road segments) to produce estimates of annual average daily characteristics. With this general approach, each state strives to provide (or help provide) estimates of annual characteristics for each road segment within its boundaries.

As with almost any data collection effort, the monitoring data suffer from errors from many sources. This report summarizes results of a two year empirical research effort, which was sponsored by the Federal Highway Administration, (i) to study and characterize the variability in the traffic data (volume, classification, and weight) from the continuously monitored road segments, and (ii) to study the extent to which this variability is transferred to, and affects the precision of the data produced from the road segments which are monitored only one or two days each year. The ultimate hope is not only that states will eventually be able to publish an estimate of a characteristic such as AADT for each road segment, but also that each estimate will be accompanied by a statement of how good the estimate is in terms of the estimated variability or precision which will likely be experienced as a coefficient of variation (i.e., the quotient of a standard deviation and a mean).

This report provides highlights of research reported in five working papers. It should be emphasized that results from this project are based on a few continuously monitored sites from two states Florida and Washington. Thus, we recommend that data from more sites across a sample of representative states be analyzed in the future to validate the findings from this effort. Significant findings are highlighted below. 
1. Weekend days, winter months and holidays contribute substantially to the variability observed in traffic data. These results confirm the need to annualize short-term monitored data by day-of-theweek and month-of-the-year factors. Without properly adjusting short-term monitored data to reflect these temporal variations, the resulting traffic estimates are biased.
The main contributors to the variance in traffic were examined. The larger contributors to traffic count variability are the weekend days rather than the weekdays, the winter months rather than the summer months, and the "all holiday period" days rather than the "non-holiday period" days. These findings confirm the need to annualize data collected from short-term monitored sites, at a minimum, by day-of-week and

month-of-the-year factors. These findings also provide guidance should one decide to consider sampling a statistically representative data from the continuously monitoring sites so that data processing effort can be reduced. (See details on page 48).

To study and characterize the variability in the traffic data (volume, classification, and weight) from the continuously monitored road segments, we calculated AADT, AADT by vehicle class, and ESAL and average daily weight per vehicle by vehicle class. Furthermore, we estimated the corresponding coefficients of variation.

2. The more common the vehicle type, the less variability in the traffic volume. To achieve more reliable AADT estimates, less common vehicle classes should be combined.

In general, we found that high volume traffic estimates have low associated coefficients of variation, while low volume traffic estimates have high associated coefficients of variation. This is especially illustrated in the classification data. This finding suggests that less common vehicle classes (those account for less than $1 \%$ of the daily traffic volume) should be combined in order to achieve reliable AADT estimates. (See details on page 10). 
The variability among the weekend daily traffic counts is higher than the variability among weekday daily traffic counts. As commonly known, traffic volume on weekend days is lower than traffic volume on weekdays. Similar results hold for classification data and weigh-in-motion data. These observed differences between weekend day data and weekday data confirm the need to annualize short-term monitored

3. "Day-of-the-week" variance in traffic volume and loading is significant, indicating that adjustment of the short-term monitored data by, at least, weekday and weekend factors is essential.

data by day of week factors, or at least by weekday and weekend factors. Traffic estimates based on unadjusted/unweighted data from the short-term monitored sites are biased. (See details on page 22).

4. Total traffic volume, the size of the vehicles, and the loads imposed on the roads vary from one month to the next. Without adjusting short-term monitored data to account for this monthly variation, the estimates will be biased.
For the different vehicle classes, the larger coefficients of variation associated with the estimated traffic loadings tend to occur during days in

January and July, while the lower coefficients of variation tend to occur during days in March and April. The level of the coefficients of variation for "day-of-week" is about the same as the level of the coefficients of variation for "month of the year" for both ESAL estimates and weight estimates. These observed monthly variations confirm the need to annualize by month-of-the-year factors, or at least by seasonal factors. Again, without properly adjusting the short-term monitored data to account for this monthly variation, the traffic estimates will be biased. (See details on page 25). 
5. There are five different methods for estimating average traffic characteristics -- ranging from simple to complex. Our results show that almost all five methods produce estimates of traffic characteristics that are within $5 \%$ of each other. As a result, we recommend the straight forward averaging method because of its simplicity!

Five methods for estimating average characteristics were examined and compared. These methods included the AASHTO method. Because no practical differences were observed among the estimates produced by the five different approaches, we recommended the straight average for simplicity! This method calls for computing the average of the daily traffic estimates. Our results show that almost all five estimates of annual traffic estimates (AADT, AADT by vehicle class, daily ESAL and weight per vehicle) are within $5 \%$ of each other. (See details on page 31 ).

Continuous traffic monitoring is plagued by missing data which seems to mainly be due to equipment failure, construction schedules, and installation dates.

6. The effects of randomly missing data on annual traffic estimates are negligible. However, the more missing data, the more unreliable the estimates. In many cases, we found that the loss of reliability is tolerable

However, data do not appear to be missing in any systematic patterns (i.e., for certain hours of the day, days of the week, nor months of the year.) Rather, data are missing on isolated days as well as on consecutive days. Our simulations indicate that the amount of randomly missing data had negligible effects on the traffic estimates and the associated coefficients of variation for the sites included in this study. However, as the amount of randomly missing data increases, the more unreliable the estimates, even though they are on target (on average). In many cases, the loss of reliability is tolerable. (See details on page 34). 
Traffic characteristics were calculated under three scenarios - (1) with all available data, (2) with data associated with all specific holidays removed, and (3) with data associated with all "holiday period" days

7. At most of the sites examined, there is less travel during holidays and holiday periods than during non-holidays. Although the effect of holiday and special days is small on the estimates of total traffic and classification data, but it is not negligible on the corresponding coefficients of variations. removed. "Holiday period" days are a specific holiday plus the adjacent days. For example, the "holiday period" days for the July 4 holiday in 1994 include July 1 through 7. Our results show that at most of the sites examined there is less travel during holidays and holiday periods than during nonholidays. However, the differences are negligible - within $2 \%$ of each other. Although the effect of holidays and holiday periods appears negligible on the traffic estimates, the effect on CV (i.e., variability) is small, but not negligible. CV's decrease when holidays and holiday periods are removed, indicating that there is more traffic variability during holiday periods. (See details on page 45).

8. Traffic differs significantly by direction. Traffic monitoring needs to be conducted in both directions!

$T_{\text {he }}$ analysis of count and classification data by direction of travel shows that traffic differs significantly by direction. This finding is significant in practice because it confirms the need to monitor traffic volume and classification data in both directions instead of just monitoring in one direction and multiplying the result by two. (The details are presented on page 7). 
9. In general, adjustment factors based on data from the continuously monitored sites of similar functional classes work reasonably well in "expanding" 24 hours of traffic volume into an annual estimate. However, the ability of this approach to estimate vehicle classification counts decreases the less common the vehicle. Also, the ability of this approach to estimate traffic loadings deteriorates for vehicle classes with widely varying weights.

We conducted simulation studies to study the extent to which the variability in the traffic data collected from continuously monitored road segments is transferred to, and affects, the precision of the estimates based on data from the short-term monitored sites. In this simulation, we created seasonal (monthly) adjustment factors and dayof-week factors based on data from the continuously monitored sites. Given these factors, we considered that we have only one day's ( 24 hour period) worth of data from each of the continuous monitored sites. That is, we assumed that the site is a short-term monitored site. Given the factors and the 24 hour period of data, we calculated annual estimates of traffic characteristics (i.e., AADT, and AADT by vehicle class). The precision of an estimate from treating the site as a continuously monitored site (the original estimate) is compared to the precision of an estimate from treating that site as a short-term monitored site (the simulated estimate). The original estimates of traffic characteristics (i.e., AADT, AADT by vehicle class, and daily ESAL per vehicle) are, on average, quite close to the simulated estimates. Based on the maximum ratio, the original AADT estimate and the simulated AADT estimate at a given site are, on average, within $2 \%$ of each other. Not surprisingly, the original estimates appear to be more precise, on average, than the simulated estimates. The decrease in the precision typically occurs for vehicle classes that account for less than $1 \%$ of daily traffic volume, suggesting that these less common vehicle classes should be combined in order to achieve reliable AADT estimates. In almost all cases, the simulated estimates tend to be higher than the original estimates, possibly suggesting some (slight) positive bias in the simulated estimates. In general, adjustment factors based on data from the continuously monitored sites of similar functional classes work reasonably well in "expanding" 24 hours of traffic data into an annual estimate. (See details on page 52). 
10. Although they serve different purposes, truck weight estimates (in kips) and ESAL estimates have different corresponding coefficients of variation $(\mathrm{CV})$. ESAL estimates have highér CVs than weight estimates.

Coefficients of variation for truck weight data (in kips) are generally lower and have smaller ranges than the coefficients of variation for ESAL. This pattern repeats itself in the temporal estimates weekend verse weekdays, winter months verse summer months, etc. In general, daily weight estimates appear to be more reliable than the corresponding daily ESAL estimates. Since these two estimates meet different analytical needs, whether and how one can substitue the other should be investigated in more detail. If not, then research should be undertaken to understand how short-term ESAL can be annualized to produce reliable estimates of annual ESAL.

\section{Recommendations}

1. Since continuous monitoring data are plagued by missing data and since our results show that randomly missing data have little effect on traffic estimates and on the estimated coefficients of variation, we recommend that research be supported to determine to what extent sampling can assist continuous traffic monitoring programs. Rather than process the complete continuous monitoring traffic data on a continuous basis, one option is to develop annual traffic estimates based on a statistically representative sample of these data. These estimates can be periodically updated with a more current sample of continuous data. Another option is to sample data collected from Intelligent Transportation System (ITS) developments to characterize traffic patterns.

2. Conduct research to investigate the advantages and disadvantages of combining certain vehicle classes. Four results prompt this recommendation. First, high coefficients of variation associated with $\mathrm{AADT}$ tend to occur with vehicle classes that have extremely low mean daily traffic volumes. Second, at almost every one of the eight classification sites, the level of unclassified/other vehicles is quite high relative to what is captured 
in other vehicle classes. The large percentage of vehicles being unclassified (Class 14) may signal some concern for the reported counts in the other classes. Third, for vehicle classes with low mean daily traffic volumes, traffic estimates calculated using five estimation approaches are rather different. Fourth, the estimates of traffic characteristics derived from treating the site as a continuously monitored site appear to be more precise, on average, than the simulated estimates from treating the site as a short-term monitored site. This decrease in precision typically occurs for vehicle classes that account for less than $1 \%$ of daily traffic volume, suggesting that these less common vehicle classes should be combined in order to achieve reliable AADT estimates.

3. Monitor traffic in both directions. The analysis of count and classification data by direction of travel shows that traffic differs significantly by direction. This finding is significant in practice because it confirms the need to monitor traffic volume and classification data in both directions instead of just monitoring in one direction and multiplying the result by two.

4. Monitor missing data and use graphics and exploring data analysis methods to easily reveal systematic patterns of missing data. Systematic patterns of missing data signal potential equipment problems, thereby providing valuable information for maintenance scheduling. Furthermore, patterns of missing data help guide users against inappropriate analysis and misinterpretation of the data.

5. To better aid the development of highway strategies with accurate and timely traffic characteristics, we propose that traffic data analysis programs in each state include, at a minimum:

(i) - data editing methods (such as the approaches used by Florida Department of Transportation),

(ii) tracking of missing data at each continuously monitored site using graphics,

(iii) development of adjustment factors for AADT estimates from short-term, monitored sites as discussed in [1] and illustrated in [7].

(iv) computation of total volume averages by day of week and month of year at volume sites,

(v) computation of volume and percentages of each vehicle class by day of week and month of year at each classification site, 
(vi) computation of average weight and ESAL per day and month at each WIM site,

(vii) computation of CVs for publication with AADTs for continuously monitored sites, and

(viii) computation of AADT for continuously monitored sites using simple averages, including in the presence of missing data that do not show a systematic missing pattern.

Also, we recommend that these analyses be conducted on a periodic basis to: verify traffic estimates, identify changes in traffic patterns, and detect and correct equipment malfunction in a timely manner. 


\section{TABLE OF CONTENTS}

Page

ACKNOWLEDGMENTS $\ldots \ldots \ldots \ldots \ldots \ldots \ldots \ldots \ldots \ldots \ldots \ldots \ldots \ldots \ldots$ ii

EXECUTIVE SUMMARY $\ldots \ldots \ldots \ldots \ldots \ldots \ldots \ldots \ldots \ldots \ldots \ldots \ldots \ldots$

LIST OF TABLES $\ldots \ldots \ldots \ldots \ldots \ldots \ldots \ldots \ldots \ldots \ldots \ldots \ldots \ldots \ldots \ldots \ldots \ldots$

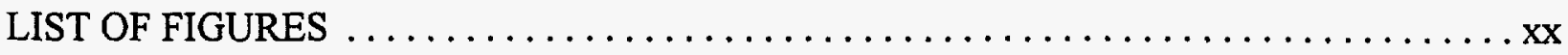

1. INTRODUCTION AND OBJECTIVES $\ldots \ldots \ldots \ldots \ldots \ldots \ldots \ldots \ldots \ldots \ldots \ldots \ldots$

2. DESCRIPTION OF SITES USED $\ldots \ldots \ldots \ldots \ldots \ldots \ldots \ldots \ldots \ldots \ldots \ldots \ldots \ldots$

3. SELECTED PRELIMINARY RESULTS FROM THE PILOT STUDY $\ldots \ldots \ldots \ldots \ldots \ldots 7$

3.1 Differences in Direction of Travel $\ldots \ldots \ldots \ldots \ldots \ldots \ldots \ldots \ldots \ldots \ldots$

3.2 Annual Traffic Estimates and Associated Coefficients of Variation . . . . . . . . 10

3.3 Coefficients of Variation (CV) by "Day of Week" . . . . . . . . . . . . 15

3.3.1 Coefficients of Variation (CV) for AADT by "Day of Week" . . . . . . . 15

3.3.2 Coefficients of Variation (CV) for AADT by Vehicle Class

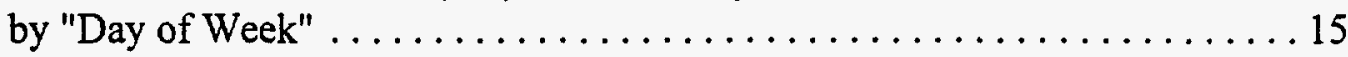

3.3.3 Coefficients of Variation (CV) for Daily ESAL per Vehicle

Ranging Over "Days of Week" . . . . . . . . . . . . . . . 21

3.3.4 Coefficients of Variation (CV) for Daily Weight per Vehicle

Ranging Over "Days of Week" . . . . . . . . . . . . . . . 22

3.4 Coefficients of Variation CV by "Month of Year $\ldots \ldots \ldots \ldots \ldots \ldots \ldots \ldots \ldots$

3.4.1 Coefficients of Variation CV for AADT by "Month of Year . . . . . . . . . 25

3.4.2 Coefficients of Variation CV for AADT by Vehicle Class

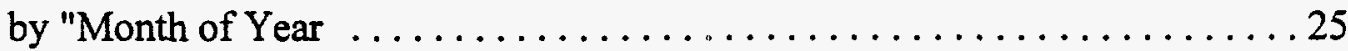

3.4.3 Coefficients of Variation CV for Daily ESAL per Vehicle by

Vehicle Class by "Month of Year . . . . . . . . . . . . . . . . 25

3.4.4 Coefficients of Variation (CV) for Average Daily Weight per

Vehicle by Vehicle Class by "Month of Year" . . . . . . . . . . . . 27

3.5 Daily Vehicle Mix . . . . . . . . . . . . . . . . . . . . . . . 28

3.6 Examination of Five Different Methods for Computing Annual Traffic Estimates . . 31

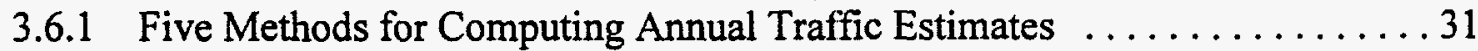

3.6.2 Preliminary Comments Based on the Empirical Comparison $\ldots \ldots \ldots \ldots 33$

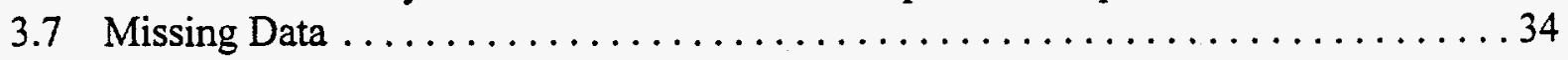

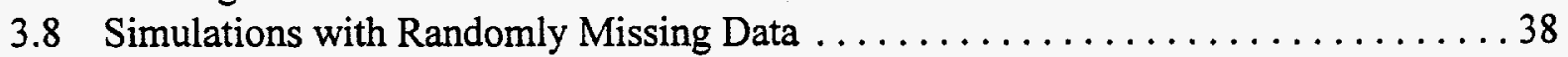

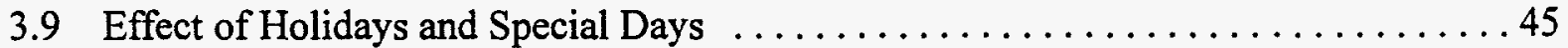

3.10 Empirical Analysis of Variance of Continuous Traffic Monitoring Data . . . . . 48 
TABLE OF CONTENTS (continued)

Page

4. PRECISION OF SHORT-TERM TRAFFIC MONITORING DATA $\ldots \ldots \ldots \ldots \ldots .52$

5. RECOMMENDATIONS FOR FUTURE TRAFFIC DATA COLLECTION

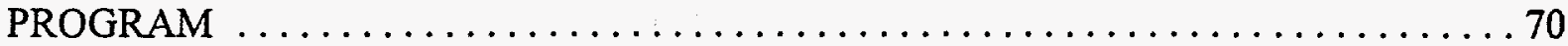

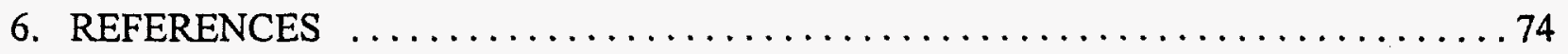

xvi 


\section{LIST OF TABLES}

Page

Table 1. Sites Used to Study the Variability in Continuous Traffic Data $\ldots \ldots \ldots \ldots \ldots 5$

Table 2. Sites Used to Study the Precision in Short-Term Monitored Traffic Data ........ 6

Table 3. Results of Paired $t$ Tests Comparing the Average Counts in Both Directions by Site and Day of the Week $\ldots \ldots \ldots \ldots \ldots \ldots \ldots \ldots \ldots$

Table 4. Summary Results on Differences in Directional Classification Data by

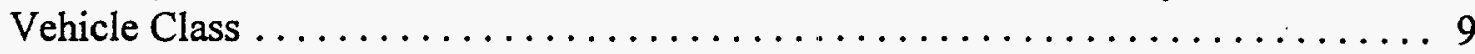

Table 5. 1994 Estimated AADT and Associated Coefficients of Variation (CV) . . . . . . 10

Table 6. 1994 Estimated Mean Daily Count (AADT*) by Vehicle Class and Associated Coefficients of Variation (Based on 8 Florida Classification Sites) . . . . . . . . 11

Table 7. 1994 Estimated Average Daily ESAL* per Vehicle, AADT and Associated Coefficients of Variation by Vehicle Class (6 Washington

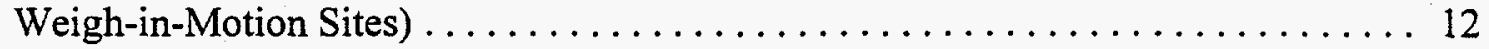

Table 8. 1994 Estimated Average Daily Weight* per Vehicle (Kips), AADT and Associated Coefficients of Variation by Vehicle Class ( 6 Washington Weigh-in-Motion Sites) .

Table 9. CV Ranges Over Days of Week for AADT Over Florida's 21 Count Sites ...... 15

Table 10. Ranks of the Mean Daily Traffic Volumes By Vehicle Class Over the Days of the Week Based on the 8 Classification Sites $\ldots \ldots \ldots \ldots \ldots \ldots \ldots \ldots \ldots$

Table 11. Ranks of the Coefficients of Variation for Traffic Volumes By Vehicle Class Over the Days of the Week Based on the 8 Classification Sites ........... 18

Table 12. CV Ranges over Days of Week for "ESAL" for Each Vehicle Class at Each of the 6 Washington Weigh-In-Motion Sites

Table 13. CV Ranges over Days of Week for "Weight" for Each Vehicle Class at Each of the 6 Weigh-In-Motion Sites from Washington 


\section{LIST OF TABLES (continued)}

\section{Page}

Table 14. CV Ranges Over Months of Year for AADT over Florida's 21 Count Sites (\%) . . . 25

Table 15. CV Ranges Over Months of Year for.Each Vehicle Class at Each of the 8 Classification Sites from Florida $\ldots \ldots \ldots \ldots \ldots \ldots \ldots \ldots \ldots \ldots \ldots$

Table 16. CV Ranges over Months of Year for "ESAL" for Each Vehicle Class at Each of the 6 Weigh-In-Motion Sites from Washington $\ldots \ldots \ldots \ldots \ldots \ldots \ldots$

Table 17. CV Ranges over Months of Year for "Weight" for Each Vehicle Class at Each of the 6 Weigh-In-Motion Sites from Washington $\ldots \ldots \ldots \ldots \ldots \ldots 27$

Table 18. 1994 Daily Vehicle Mix Based on Florida's 8 Classification Sites . . . . . . . . . 29

Table 19. Potential Grouping Scheme of Vehicles ...................... 29

Table 20. A Comparison AADT Computed Estimates by the Five Different Methods ..... 32

Table 21. Graphic of Missing Days for the 21 Selected Sites from Florida's District 5

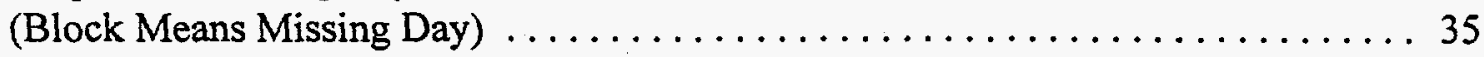

Table 22. Graphic of Missing Days for the 8 Selected Classification Sites from Florida's District 5 (Block Means Missing Day) $\ldots \ldots \ldots \ldots \ldots \ldots \ldots \ldots$

Table 23. Graphic of Missing Days for the 6 Selected WIM Sites from Washington

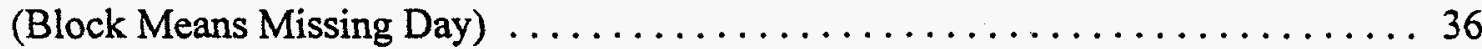

Table 24. 1994 Missing Days of Classification Data by Days of Week .............. 37

Table 25. 1994 Missing Days of Classification Data by Months of Year ............ 37

Table 26. Simulation Results for AADT 1 with Randomly Missing Days of Count Data .... 40

Table 27. Simulation Results for CV with Randomly Missing Days of Count Data ....... 44

Table 28. Effect of Holidays and Special Days on AADT and CV (\%) $\ldots \ldots \ldots \ldots \ldots 47$

Table 29. Overall Ranking for Contributions to Variability of Traffic Count Data by Days of Week (based on 21 Florida count sites) 


\section{LIST OF TABLES (continued)}

Page

Table 30. Overall Ranking for Contributions to Variability of Traffic Count Data by Months of Year (based on 21 Florida count sites)

Table 31. Overall Ranking for Contributions to Variability of Traffic Classification Data by Days of Week (based on 8 Florida Classification Sites) $\ldots \ldots \ldots \ldots \ldots \ldots 0$

Table 32. Overall Ranking for Contributions to Variability of Traffic Classification Data by Months of Year (Based on 8 Florida Classification Sites) . . . . . . . . . . 51

Table 33. Precision of Original and Simulated AADTs (Based on 20 Florida Count Sites) . . 54

Table 34. Precision of Original and Simulated AADTs by Vehicle Classes for 8 Florida Classification Sites . . . . . . . . . . . . . . . . . . . . 57

Table 35. Precision of Original and Simulated AADTs by Vehicle Classes for Washington's Weigh-In-Motion Sites

Table 36. Precision of Original and Simulated ESALs by Grouped Vehicle Classes For Washington's Weigh-In-Motion Sites 66

Table 37. Range of Coefficients of Variation (CV) and Estimated Precision of the Original and the Simulated ESAL Estimates For 3 Washington's Weigh-In-Motion Sites ... 


\section{LIST OF FIGURES}

Page

Figure 1 Vehicle Class Mean Daily Traffic Counts and Coefficients of Variation by Day of Week for Florida Classification Site $9925 \ldots \ldots \ldots \ldots \ldots \ldots$

Figure 2 Ranges of "Day of Week" AADT and Associated CV by Vehicle Class (based on 8 Florida Classification Sites)

Figure 3 Example of Combined and Class Empirical Distributions of 1994 Daily

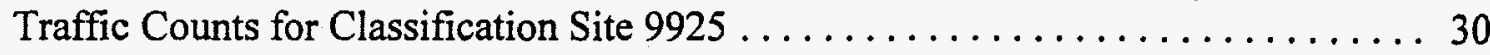




\title{
1. INTRODUCTION AND OBJECTIVES
}

Within each state, traffic data are important for supporting highway needs; furthermore the need exists to better understand and analyze the available data to support improved decision making. Toward this end, each state in the United States has a system of roads and highways which are usually defined as a universe of road segments. A road segment is a definite section of a state road often having the same features (e.g., grade, number of lanes, geometry, etc.). For each road segment in each state, this report assumes that it is desired to know various traffic characteristics including:

\author{
Count (Volume) Data - Annual Average Daily Traffic (AADT) \\ Classification Count Data - AADT for Each Vehicle Class \\ Weigh-In-Motion Data - Annual Average Daily Equivalent Single Axle Loadings \\ (ESAL) per Vehicle for Each Vehicle Class \\ - Annual Average Daily Weight per Vehicle for Each Vehicle \\ Class
}

These data are absolutely essential for highway maintenance and planning, especially AADT. (Actually, most states currently only use annualized count data, i.e. AADT. Classification and weight data are generally not annualized by the states as will be discussed in this report.) Given no cost constraints, each road segment would be continuously monitored every day of the year to determine values of the four traffic characteristics just noted as well as many others. However, in practice, a few road segments are monitored continuously every day of the year to produce annual characteristics of traffic flow. The remaining road segments are monitored for one or two days each year, and this resulting data are "adjusted" (using factors based on data collected from the continuously monitored road segments) to produce estimates of annual average daily characteristics. With this general approach, each state strives to provide (or help provide) estimates of annual characteristics for each road segment within its boundaries. In 1995, the Federal Highway Administration published its latest edition of the Traffic Monitoring Guide [1] to assist states in achieving this end.

\section{Objective of Research Study}

As with almost any data collection effort, the monitoring data suffer from errors from many sources. The objectives of this two year research effort, which is sponsored by the Federal Highway 
Administration, are (i) to study and characterize the variability in the traffic data (volume, classification, and weight) from the continuously monitored road segments, and (ii) to study the extent to which this variability is transferred to, and affects the precision of, the data produced from the road segments which are monitored only one or two days each year. The ultimate hope is not only that states will eventually be able to publish an estimate of a characteristic such as AADT for each road segment but also that each estimate will be accompanied by a statement of how good the estimate is in terms of its estimated variability or precision which will likely be expressed as a coefficient of variation (i.e., the quotient of a standard deviation and a mean). While variability is indeed the main objective, other objectives include data analysis of traffic data from continuously monitored sites, data utility to the transportation community, developing data analysis capability, and support highway information needs.

\section{Overall Research Approach}

The approach being followed for this research study can be viewed in three major steps.

Step 1: Initial Methodology Development for Data Collected from Continuously Monitored Sites Using 1994 data from continuously monitored sites in Florida and Washington and elementary statistical methods, it was decided to first develop a methodology for estimating variability in data from a few sites as follows:

\section{(a) Count Data}

We used the 1994 traffic count data from 21 of Florida's continuously monitored count sites. Details are given in Variability in Continuously Traffic Monitoring Data-Task II Report: Pilot Methodology Development and Estimates of Variability from Continuous Traffic Count Data [2].

(b) Classification Count Data

We used the 1994 traffic classification count data from 8 of Florida's continuously monitored classification sites. Details are given in Variability in Continuous Traffic Monitoring Data-Task V Report: Pilot Methodology Development and Estimates of Variability from Continuous Classification Count Data [3].

(c) Weigh-In-Motion Data

We used the 1994 traffic ESAL and weight data from 6 of Washington's continuously monitored weigh-in-motion sites. Details are given in Variability in 
Continuous Traffic Monitoring Data-Task VIII Report: Pilot Methodology Development and Estimates of Variability from Continuous Traffic Weigh-In-Motion Data [4].

Step 2: Variability at Short-Term Monitored Sites

We studied how and to what extent variability in data obtained from continuously monitored sites is transferred to annual traffic estimates based on data from short-term monitored sites [7].

Step 3: Guidance for States

Based on results from Steps 1 and 2, we propose, for states to consider, a method for reporting variability in traffic estimates for continuously monitored sites and precision in traffic estimates for short-term monitored sites.

For details, please refer to the following reports of the Center for Transportation Analysis of the Oak Ridge National Laboratory in Oak Ridge, Tennessee:

Variability in Florida Continuous Traffic Monitoring Data (Working Draft Paper - Task I Report), May 31, 1995,

Variability in Continuous Traffic Monitoring Data Task II Report: Pilot Methodology Development and Estimates of Variability from Continuous Traffic Count Data, October 1995,

Variability in Continuous Traffic Monitoring Data Task V Report: Pilot Methodology Development and Estimates of Variability from Continuous Traffic Classification Count Data, January 1996,

Variability in Continuous Traffic Monitoring Data Task VIII Report: Pilot Methodology Development and Estimates of Variability from Continuous Traffic Weigh-in-Motion Data, April 1996 , and

Variability in Continuous Traffic Monitoring Data Tasks IV, VII, and X Report: Precision in Estimates of AADT and AADT by Vehicle Class for Short-Term Traffic Monitoring Sites and Its Relation to Variability in Estimates for Continuously Monitored Sites, November 1996. 


\section{DESCRIPTION OF SITES USED}

Data used to study and characterize the variability in the continuous traffic data come from the sites as described in Table 1. In general, we attempted to select sites for this study which had at least 200 days of 1994 data in both directions of traffic at the site. Note that what may appear to be some inconsistencies in Table 1 actually are not. For example, for Site 9925, we show 308 days of count data with an AADT value of 12,661 vehicles. However, for Site 9925, we show 307 days of classification count data with an AADT value of 12,909 vehicles. The primary difference in the AADT for Site 9925 between the count and classification count data is not due to the difference in the number of days of data used. Rather, the difference is due to the discrepancy in the total volume of the count data and the total volume of the classification count data (total volume for the classification count data was determined by summing the counts in each of the classes). This type of discrepancy was observed for 10 different dates. This is shown in Table 2.2 of Variability in Continuous Traffic Monitoring Data-Task V Report: Pilot Methodology Development and Estimates of Variability from Continuous Traffic Classification Count Data [3]. Our analysis is based on the data received from Florida, without further editing.

Sites in Table 2 are those used to study the extent to which the variability observed in continuous traffic data is transferred to, and affects the precision of, the data produced from the roads which are monitored only one or two days each year. More sites were included to study the precision since at least two sites within each major road type (e.g., urban interstates, urban others, rural interstates, and rural others) are needed to calculate corresponding adjustment factors. 
Table 1.

Sites Used to Study the Variability in Continuous Traffic Data

\begin{tabular}{|c|c|c|c|c|c|c|}
\hline & State & Data Type & Site & Functional Class & $\begin{array}{l}\text { Number of Days } \\
\text { of Available Data }\end{array}$ & $\begin{array}{l}\text { Approximate } \\
1994 \text { AADT }\end{array}$ \\
\hline 1. & Florida & Count & 119 & Rural Principal Arterial Interstate [01] & 212 & 30,180 \\
\hline 2. & Florida & Count & 223 & Rural Principal Arterial Other [02] & 231 & 4,474 \\
\hline 3. & Florida & Count & 65 & Rural Principal Arterial Other [02] & 322 & 7,382 \\
\hline 4. & Florida & Count & 9925 & Rural Principal Arterial Other [02] & 308 & 12,661 \\
\hline 5. & Florida & Count & 104 & Rural Principal Arterial Other [02] & 347 & 22,098 \\
\hline 6. & Florida & Count & 118 & Rural Principal Arterial Other [02] & 345 & 22,262 \\
\hline 7. & Florida & Count & 170 & Rural Minor Arterial [06] & 353 & 5,284 \\
\hline 8. & Florida & Count & 136 & Rural Major Collector [07] & 263 & 6,336 \\
\hline 9. & Florida & Count & 133 & Urban Principal Arterial Interstate [11] & 283 & 28,026 \\
\hline 10. & Florida & Count & 179 & Urban Principal Arterial Interstate [11] & 210 & 54,599 \\
\hline 11. & Florida & Count & 130 & Urban Principal Arterial Interstate [11] & 341 & 110,865 \\
\hline 12. & Florida & Count & 196 & Urban Principal Arterial Interstate [11] & 252 & 154,304 \\
\hline \multirow[t]{2}{*}{13.} & Florida & Count & 204 & Urban Principal Arterial Other Freeway/ & 212 & \\
\hline & & & & Expressway [12] & & 28,294 \\
\hline 14. & Florida & Count & 114 & Urban Principal Arterial Other [14] & 267 & 14,436 \\
\hline 15. & Florida & Count & 177 & Urban Principal Arterial Other [14] & 333 & 33,290 \\
\hline 16. & Florida & Count & 102 & Urban Principal Arterial Other [14] & 278 & 40,753 \\
\hline 17. & Florida & Count & 154 & Urban Principal Arterial Other [14] & 220 & 44,030 \\
\hline 18. & Florida & Count & 113 & Urban Principal Arterial Other [14] & 326 & 45,825 \\
\hline 19. & Florida & Count & 197 & Urban Principal Arterial Other [14] & 212 & 47,270 \\
\hline 20. & Florida & Count & 246 & Urban Minor Arterial [16] & 278 & 7,681 \\
\hline 21. & Florida & Count & 175 & Urban Minor Arterial [16] & 342 & 39,920 \\
\hline 1. & Florida & Classification & 9925 & Rural Principal Arterial Other [02] & 307 & 12,909 \\
\hline 2. & Florida & Classification & 170 & Rural Minor Arterial [06] & 353 & 5,284 \\
\hline 3. & Florida & Classification & 114 & Urban Principal Arterial Other [14] & 266 & 14,447 \\
\hline 4. & Florida & Classification & 177 & Urban Principal Arterial Other [14] & 284 & 33,540 \\
\hline 5. & Florida & Classification & 113 & Urban Principal Arterial Other [14] & 323 & 45,867 \\
\hline 6. & Florida & Classification & 197 & Urban Principal Arterial Other [14] & 212 & 47,270 \\
\hline 7. & Florida & Classification & 246 & Urban Minor Arterial [16] & 277 & 7,686 \\
\hline 8. & Florida & Classification & 175 & Urban Minor Arterial [16] & 342 & 39,920 \\
\hline 1. & Washington & Weigh-In-Motion & P10 & Rural Principal Arterial Interstate [01] & 282 & $1653^{*}$ \\
\hline 2. & Washington & Weigh-In-Motion & P05 & Rural Principal Arterial Other [02] & 346 & $377^{*}$ \\
\hline 3. & Washington & Weigh-In-Motion & P17 & Rural Minor Arterial [06] & 364 & $425^{*}$ \\
\hline 4. & Washington & Weigh-In-Motion & P29 & Urban Principal Arterial Interstate [11] & 365 & $4,180^{*}$ \\
\hline 5. & Washington & Weigh-In-Motion & P19 & $\begin{array}{l}\text { Urban Principal Arterial Other Freeway/ } \\
\text { Expressway [12] }\end{array}$ & 365 & $2314^{*}$ \\
\hline 6. & Washington & Weigh-In-Motion & P07 & Urban Principal Arterial Other [14] & 334 & $281^{*}$ \\
\hline
\end{tabular}


Table 2.

Sites Used to Study the Precision in Short-Term Monitored Traffic Data

\begin{tabular}{|c|c|c|c|c|c|c|}
\hline & State & Data Type & Site & Functional Class & $\begin{array}{l}\text { Number of Days } \\
\text { of Available Data }\end{array}$ & $\begin{array}{l}\text { Approximate } \\
\text { 1994 AADT }\end{array}$ \\
\hline 1. & Florida & Count & 223 & Rural Principal Arterial Other [02] & 231 & 4,474 \\
\hline 2. & Florida & Count & 65 & Rural Principal Arterial Other [02] & 322 & 7,382 \\
\hline 3. & Florida & Count & 9925 & Rural Principal Arterial Other [02] & 308 & 12,661 \\
\hline 4. & Florida & Count & 104 & Rural Principal Arterial Other [02] & 347 & 22,098 \\
\hline 5. & Florida & Count & 118 & Rural Principal Arterial Other [02] & 345 & 22,262 \\
\hline 6. & Florida & Count & 170 & Rural Minor Arterial [06] & 353 & 5,284 \\
\hline 7 & Florida & Count & 136 & Rural Major Collector [07] & 263 & 6,336 \\
\hline 8. & Florida & Count & 133 & Urban Principal Arterial Interstate [11] & 283 & 28,026 \\
\hline 9. & Florida & Count & 179 & Urban Principal Arterial Interstate [11] & 210 & 54,599 \\
\hline 10. & Florida & Count & 130 & Urban Principal Arterial Interstate [11] & 341 & 110,865 \\
\hline 11. & Florida & Count & 196 & Urban Principal Arterial Interstate [11] & 252 & 154,304 \\
\hline 12. & Florida & Count & 204 & $\begin{array}{l}\text { Urban Principal Arterial Other Freeway/ } \\
\text { Expressway [12] }\end{array}$ & 212 & 28,294 \\
\hline 13. & Florida & Count & 114 & Urban Principal Arterial Other [14] & 267 & 14,436 \\
\hline 14. & Florida & Count & 177 & Urban Principal Arterial Other [14] & 333 & 33,290 \\
\hline 15. & Florida & Count & 102 & Urban Principal Arterial Other [14] & 278 & 40,753 \\
\hline 16. & Florida & Count & 154 & Urban Principal Arterial Other [14] & 220 & 44,030 \\
\hline 17. & Florida & Count & 113 & Urban Principal Arterial Other [14] & 326 & 45,825 \\
\hline 18. & Florida & Count & 197 & Urban Principal Arterial Other [14] & 212 & 47,270 \\
\hline 19. & Florida & Count & 246 & Urban Minor Arterial [16] & 278 & 7,681 \\
\hline 20. & Florida & Count & 175 & Urban Minor Arterial [16] & 342 & 39,920 \\
\hline 1. & Florida & Classification & 9925 & Rural Principal Arterial Other [02] & 307 & 12,909 \\
\hline 2. & Florida & Classification & 170 & Rural Minor Arterial [06] & 353 & 5,284 \\
\hline 3. & Florida & Classification & 114 & Urban Principal Arterial Other [14] & 266 & 14,447 \\
\hline 4. & Florida & Classification & 177 & Urban Principal Arterial Other [14] & 284 & 33,540 \\
\hline 5. & Florida & Classification & 113 & Urban Principal Arterial Other [14] & 323 & 45,867 \\
\hline 6. & Florida & Classification & 197 & Urban Principal Arterial Other [14] & 212 & 47,270 \\
\hline 7. & Florida & Classification & 246 & Urban Minor Arterial [16] & 277 & 7,686 \\
\hline 8. & Florida & Classification & 175 & Urban Minor Arterial [16] & 342 & 39,920 \\
\hline 1. & Washington & Weigh-In-Motion & P05 & Rural Principal Arterial Other [02] & 346 & $377^{*}$ \\
\hline 2. & Washington & Weigh-In-Motion & $\mathrm{P} 17$ & Rural Minor Arterial [06] & 364 & $425^{*}$ \\
\hline 3. & Washington & Weigh-In-Motion & $\mathrm{P} 03$ & Rural Minor Arterial [06] & 331 & $773^{*}$ \\
\hline 4. & Washington & Weigh-In-Motion & P29 & Urban Principal Arterial Interstate [11] & 365 & $4,180^{*}$ \\
\hline 5. & Washington & Weigh-In-Motion & $\mathrm{P} 3 \mathrm{~N}$ & Urban Principal Arterial Interstate [11] & 364 & $3266^{*}$ \\
\hline 6. & Washington & Weigh-In-Motion & P5S & Urban Principal Arterial Interstate [11] & 288 & $3101^{*}$ \\
\hline 7. & Washington & Weigh-In-Motion & P19 & $\begin{array}{l}\text { Urban Principal Arterial Other Freeway/ } \\
\text { Expressway [12] }\end{array}$ & 365 & $2314^{*}$ \\
\hline 8. & Washington & Weigh-In-Motion & $\mathrm{P} 20$ & $\begin{array}{l}\text { Urban Principal Arterial Other Freeway/ } \\
\text { Expressway [12] }\end{array}$ & 362 & $3173^{*}$ \\
\hline 9. & Washington & Weigh-In-Motion & P07 & Urban Principal Arterial Other [14] & 334 & $281^{*}$ \\
\hline
\end{tabular}




\section{SELECTED PRELIMINARY RESULTS ON THE VARIABILITY IN CONTINUOUS TRAFFIC MONITORING DATA}

The reader is reminded that every result or remark in this study is based on a few selected continuously monitored sites from Florida and Washington states.

\subsection{Differences in Direction of Travel}

For each of Florida's 21 count sites and each "day of the week," we hypothesize that there was a difference between the mean daily traffic volume in direction 1 and the mean traffic volume in direction 2. Similarly, for each of Florida's 8 classification sites, for each "day of the week," and for each vehicle class, we hypothesize that there was a difference between the mean daily traffic volume for a specific vehicle type in direction 1 and the mean daily traffic volume for the same specific type in direction 2. To answer these questions, we used a paired $t$ test for each site and each day of the week. The complete results are given in Table 3 for the 21 count sites and results for the 8 classification sites are given in Table 4 . 
Table 3.

Results of Paired $t$ Tests Comparing the Average Counts in Both Directions by Site and Day of the Week

\begin{tabular}{|c|c|c|c|c|c|c|c|}
\hline \multirow[b]{2}{*}{ Site } & \multicolumn{7}{|c|}{ Day of the Week } \\
\hline & Sun & Mon & Tue & Wed & Thu & Fri & Sat \\
\hline 119 & * & & & & & * & \\
\hline 223 & $*$ & $*$ & $*$ & $*$ & $*$ & $*$ & $*$ \\
\hline 65 & $*$ & $*$ & $*$ & $*$ & $*$ & $*$ & \\
\hline 9925 & $*$ & & & & & $*$ & * \\
\hline 104 & & $*$ & $*$ & * & $*$ & $*$ & $*$ \\
\hline 118 & * & & & & & & \\
\hline 170 & $*$ & $*$ & $*$ & $*$ & $*$ & $*$ & \\
\hline 136 & * & $*$ & * & * & $*$ & * & * \\
\hline 133 & $*$ & $*$ & & * & $*$ & * & $*$ \\
\hline 179 & * & & & & $*$ & & * \\
\hline 130 & * & * & * & * & * & * & * \\
\hline 196 & * & * & * & * & $*$ & * & \\
\hline 204 & * & $*$ & * & * & * & * & * \\
\hline 114 & $*$ & * & * & & $*$ & & * \\
\hline 177 & $*$ & * & * & * & * & * & * \\
\hline 102 & * & * & * & * & $*$ & * & $*$ \\
\hline 154 & * & * & * & * & * & * & $*$ \\
\hline 113 & * & * & $*$ & $*$ & $*$ & * & $*$ \\
\hline 197 & * & * & * & * & * & $*$ & $*$ \\
\hline 246 & $*$ & * & * & * & * & * & * \\
\hline 175 & $*$ & & * & * & $*$ & * & * \\
\hline
\end{tabular}

Note: The * means that the averages were found to be statistically different at $\alpha=.05$ level of significance. A blank means that the averages were not found to be statistically different at $\alpha=.05$ level of significance. 
Table 4.

Summary Results on Differences in Directional Classification Data by Vehicle Class

\begin{tabular}{rlc}
$\begin{array}{r}\text { Vehicle } \\
\text { Class }\end{array}$ & $\begin{array}{c}\text { Statistically Different at } \alpha=.05 \\
\text { (Paired } t \text { Test) }\end{array}$ \\
\hline (1) Motorcycles & Yes \\
(2) Passenger Cars & Yes \\
(3) Other Two-Axle, Four-Tire, Single-Unit & Yes \\
(4) Buses & Yes \\
(5) Two-Axle, Six-Tire, Single-Unit Trucks & Yes \\
(6) Three-Axle, Single-Unit Trucks & Yes \\
(7) Four-or-More Axle, Single-Unit Trucks & Yes \\
(8) Four-or-Less Axle, Single-Trailer Trucks & Yes \\
(9) Five-Axle, Single-Trailer Trucks & Yes \\
(10) Six-or-More Axle, Single-Trailer Trucks & Yes \\
(11) Five-or-Less Axle, Multi-Trailers Trucks & No* \\
(12) Six-Axle, Multi-Trailers Trucks & No* \\
(13) Seven-or-More Axle, Multi-Trailers Trucks & Yes \\
(14) Unclassified/Other & Yes \\
\hline
\end{tabular}

* Though not statistically different, the mean daily number of vehicles counted in these classes at each of the sites tended to be less that " 1 vehicle"!

\section{SUMMARY REMARKS Differences in Direction of Travel}

The analysis of count and classification data by direction of travel shows that traffic differs significantly by direction. This finding is significant in practice because it confirms the need to monitor traffic volume and classification data in both directions instead of just monitoring in one direction and multiplying the result by two. This analysis was not performed on WIM data because there are no data for separate directions. 


\subsection{Annual Traffic Estimates and Associated Coefficients of Variation}

For each of Florida's 21 count sites and using the days of available 1994 data, we computed AADT by taking the average of the daily count values. We also computed the coefficient of variation by

$$
\text { coefficient of variation }=\frac{\text { standard deviation of the daily count values }}{A A D T} X \quad 100 \%
$$

Results are in Table 5.

For each of Florida's 8 classification count sites and using the days of available 1994 data, we computed the 1994 mean daily count by vehicle class and associated coefficients of variation (Table 6). For each of Washington's 6 weigh-in-motion sites and using the days of available 1994 data, we computed, by vehicle class, the 1994 mean daily ESAL per vehicle, the 1994 mean daily weight per vehicle and associated coefficients of variation (Tables 7 and 8 , respectively). The equation used to derive ESAL values by the Washington State Department of Transportation is taken from the AASHTO Guide for Design of Pavement Structures, 1986. It is a function of the following factors: number of axles on vehicle, load on axles in 1000's of kilograms, terminal serviceability, and whether the road surface is either rigid or flexible pavement. For flexible payments, a structural number (ranging from 1-6) is needed. To compute an ESAL value applying to rigid pavements, a slab thickness (ranging from 6 to 12 inches) is needed.

Table 5.

1994 Estimated AADT and Associated Coefficients of Variation (CV)

\begin{tabular}{|c|c|c|c|c|c|c|c|c|}
\hline \multirow[b]{2}{*}{ Site } & \multicolumn{2}{|c|}{ Estimated } & \multirow[b]{2}{*}{ Site } & \multicolumn{2}{|c|}{ Estimated } & \multirow[b]{2}{*}{ Site } & \multicolumn{2}{|c|}{ Estimated } \\
\hline & AADT & $\mathrm{CV}(\%)$ & & AADT & $\mathrm{CV}(\%)$ & & AADT & $\mathrm{CV}(\%)$ \\
\hline 119 & 30,180 & 21.2 & 136 & 6,336 & 18.6 & 177 & 33,290 & 16.6 \\
\hline 223 & 4,474 & 16.5 & 133 & 28,026 & 15.4 & 102 & 40,753 & 14.4 \\
\hline 65 & 7,382 & 11.1 & 179 & 54,599 & 13.7 & 154 & 44,030 & 11.6 \\
\hline 9925 & 12,661 & 15.0 & 130 & 110,865 & 8.9 & 113 & 45,825 & 14.0 \\
\hline 104 & 22,098 & 8.0 & 196 & 154,304 & 12.2 & 197 & 47,270 & 16.1 \\
\hline 118 & 22,262 & 12.6 & 204 & 28,294 & 11.7 & 246 & 7,681 & 10.4 \\
\hline 170 & 5,284 & 12.3 & 114 & 14,436 & 13.6 & 175 & 39,920 & 22.4 \\
\hline
\end{tabular}


Table 6.

1994 Estimated Mean Daily Count (AADT*) by Vehicle Class

and Associated Coefficients of Variation

(Based on 8 Florida Classification Sites)

\begin{tabular}{|c|c|c|c|c|c|c|c|c|}
\hline $\begin{array}{l}\text { Vehicle } \\
\text { Class } \\
\end{array}$ & \multicolumn{8}{|c|}{ Classification Site ID } \\
\hline Motorcycle (1) & $12(249 \%)$ & $7(129 \%)$ & $37(179 \%)$ & $79(125 \%)$ & $23(52 \%)$ & $350(181 \%)$ & $4(79 \%)$ & $38(101 \%)$ \\
\hline 2-axle 4-tire SU (3) & $1,737(25 \%)$ & $749(21 \%)$ & $1,533(24 \%)$ & $3,189(29 \%)$ & $4,753(23 \%)$ & $3,853(31 \%)$ & $1,354(26 \%)$ & $2,897(40 \%)$ \\
\hline Bus (4) & $8(53 \%)$ & $3(82 \%)$ & $4(172 \%)$ & $22(46 \%)$ & $6(93 \%)$ & $46(151 \%)$ & $36(98 \%)$ & $42(71 \%)$ \\
\hline 2-axle 6-tire SU (5) & $176(49 \%)$ & $9(59 \%)$ & $27(72 \%)$ & $53(56 \%)$ & $59(58 \%)$ & $90(59 \%)$ & $54(55 \%)$ & $61(53 \%)$ \\
\hline $4^{+}$-axle SU (7) & $8(125 \%)$ & $11(109 \%)$ & $5(172 \%)$ & $18(65 \%)$ & $26(121 \%)$ & $11(102 \%)$ & $3(181 \%)$ & $18(151 \%)$ \\
\hline 4-axle S. Trailer (8) & $71(52 \%)$ & $72(30 \%)$ & $159(23 \%)$ & $331(36 \%)$ & $363(34 \%)$ & $375(38 \%)$ & $122(32 \%)$ & $299(51 \%)$ \\
\hline 5-axle S. Trailer (9) & $96(44 \%)$ & $45(45 \%)$ & $49(49 \%)$ & $215(55 \%)$ & $79(45 \%)$ & $159(47 \%)$ & $113(48 \%)$ & $231(30 \%)$ \\
\hline $6^{+}$-axle S. Trailer (10) & $2(96 \%)$ & $4(76 \%)$ & $6(72 \%)$ & $10(67 \%)$ & $4(83 \%)$ & $4(76 \%)$ & $1(122 \%)$ & $5(156 \%)$ \\
\hline 5-axle M. Trailer (11) & $1(140 \%)$ & $0(747 \%)$ & $0(456 \%)$ & $4(86 \%)$ & $1(149 \%)$ & $13(57 \%)$ & $0(306 \%)$ & $1(127 \%)$ \\
\hline
\end{tabular}

SU = Single Unit

* Numbers in parenthesis are the associated coefficients of variation (CV) 
Table 7.

1994 Estimated Average Daily ESAL* per Vehicle, AADT and Associated Coefficients of Variation by Vehicle Class

(6 Washington Weigh-in-Motion Sites)

\begin{tabular}{|c|c|c|c|c|c|c|c|}
\hline \multirow[b]{2}{*}{ Vehicle Class } & & \multicolumn{6}{|c|}{ Weigh-in-Motion Site ID } \\
\hline & & P10 & P05 & $\mathbf{P 1 7}$ & P29 & P19 & P07 \\
\hline \multirow[t]{2}{*}{ 2-axle 4-tire SU (3) } & ESAL & $0.01(39.0 \%)$ & $0.01(139.1 \%)$ & $0.01(211.8 \%)$ & $0.12(341.8 \%)$ & $0.01(54.4 \%)$ & $0.00(0.0 \%)$ \\
\hline & AADT & 32.3 & 14.8 & 4.7 & 30.7 & 19.8 & 0.0 \\
\hline \multirow[t]{2}{*}{ Bus (4) } & ESAL & $0.45(36.0 \%)$ & $0.59(156.0 \%)$ & $0.12(344.8 \%)$ & $0.69(47.3 \%)$ & $0.78(41.8 \%)$ & $0.46(113.2 \%)$ \\
\hline & AADT & 22.5 & 1.4 & 0.3 & 26.2 & 20.8 & 1.6 \\
\hline \multirow[t]{2}{*}{ 2-axle 6-tire SU (5) } & ESAL & $0.08(36.1 \%)$ & $0.13(76.4 \%)$ & $0.13(139.8 \%)$ & $0.12(73.1 \%)$ & $0.10(45.7 \%)$ & $0.32(72.2 \%)$ \\
\hline & AADT & 307.8 & 114.1 & 46.0 & 1197.8 & 1085.7 & 29.9 \\
\hline \multirow[t]{2}{*}{ 3-axle SU (6) } & ESAL & $0.25(44.1 \%)$ & $0.53(103.3 \%)$ & $0.28(88.3 \%)$ & $0.45(45.9 \%)$ & $0.60(32.1 \%)$ & $0.39(52.4 \%)$ \\
\hline & AADT & 30.9 & 16.2 & 10.4 & 268.0 & 243.4 & 36.3 \\
\hline \multirow[t]{2}{*}{$4^{+}$-axle SU (7) } & ESAL & $0.22(285.3 \%)$ & $0.17(294.3 \%)$ & $0.08(397.0 \%)$ & $1.02(86.5 \%)$ & $1.19(52.1 \%)$ & $0.42(220.5 \%)$ \\
\hline & AADT & 0.8 & 0.4 & 0.4 & 14.6 & 25.0 & 0.3 \\
\hline \multirow[t]{2}{*}{ 4-axle S. Trailer (8) } & ESAL & $0.27(32.9 \%)$ & $0.94(84.1 \%)$ & $0.95(92.7 \%)$ & $0.57(50.3 \%)$ & $0.36(46.2 \%)$ & $0.87(67.5 \%)$ \\
\hline & AADT & 83.4 & 27.3 & 12.2 & 317.1 & 120.4 & 8.8 \\
\hline \multirow{2}{*}{ 5-axle S. Trailer (9) } & ESAL & $0.97(30.2 \%)$ & $1.34(38.9 \%)$ & $1.64(25.2 \%)$ & $1.42(27.1 \%)$ & $0.97(34.1 \%)$ & $1.41(26.3 \%)$ \\
\hline & AADT & 811.7 & 111.1 & 185.2 & 1485.0 & 398.0 & 108.6 \\
\hline \multirow[t]{2}{*}{$6^{+}$-axle S. Trailer (10) } & ESAL & $0.84(34.5 \%)$ & $1.22(75.1 \%)$ & $0.91(50.8 \%)$ & $1.09(33.9 \%)$ & $0.85(37.0 \%)$ & $1.06(44.6 \%)$ \\
\hline & AADT & 49.3 & 13.2 & 30.3 & 146.2 & 163.1 & 28.5 \\
\hline \multirow[t]{2}{*}{ 5-axle M. Trailer (11) } & ESAL & $1.23(35.3 \%)$ & $1.35(75.3 \%)$ & $1.95(33.1 \%)$ & $1.53(37.7 \%)$ & $0.39(111.1 \%)$ & $0.77(178.3 \%)$ \\
\hline & AADT & 53.0 & 6.0 & 15.8 & 70.9 & 5.4 & 1.6 \\
\hline \multirow[t]{2}{*}{ 6-axle M. Trailer (12) } & ESAL & $0.79(38.3 \%)$ & $1.19(57.3 \%)$ & $1.77(43.9 \%)$ & $1.53(32.7 \%)$ & $1.76(42.5 \%)$ & $1.83(68.9 \%)$ \\
\hline & AADT & 65.5 & 20.5 & 30.0 & 113.6 & 15.1 & 7.0 \\
\hline \multirow[t]{2}{*}{$7^{+}$-axle M. Trailer (13) } & ESAL & $1.16(33.0 \%)$ & $1.68(52.9 \%)$ & $1.34(29.2 \%)$ & $1.56(30.4 \%)$ & $1.63(27.3 \%)$ & $1.62(25.0 \%)$ \\
\hline & AADT & 135.9 & 31.6 & 85.4 & 414.2 & 180.1 & 51.8 \\
\hline \multirow[t]{2}{*}{ Unclassified (14) } & ESAL & $0.37(289.3 \%)$ & $0.72(97.3 \%)$ & $0.47(237.6 \%)$ & $0.54(109.0 \%)$ & $0.43(75.7 \%)$ & $1.27(130.3 \%)$ \\
\hline & AADT & 60.0 & 20.5 & 4.3 & 95.4 & 37.0 & 6.2 \\
\hline
\end{tabular}

$\mathrm{SU}=$ Single Unit

Some numbers rounded to zero.

* Numbers in parenthesis are the associated coefficients of variation (CV) 
Table 8.

1994 Estimated Average Daily Weight* per Vehicle (Kips), AADT and Associated Coefficients of Variation by Vehicle Class (6 Washington Weigh-in-Motion Sites)

\begin{tabular}{|c|c|c|c|c|c|c|c|}
\hline \multirow[b]{2}{*}{ Vehicle Class } & & \multicolumn{6}{|c|}{ Weigh-in-Motion Site ID } \\
\hline & & $\mathbf{P 1 0}$ & P05 & $\mathbf{P 1 7}$ & P29 & P19 & P07 \\
\hline \multirow[t]{2}{*}{ 2-axle 4-tire Single Unit (3) } & Weight & $11.4(10.2 \%)$ & $8.4(24.4 \%)$ & $10.0(30.4 \%)$ & $14.1(83.5 \%)$ & $10.9(10.3 \%)$ & $0.0(0.0 \%)$ \\
\hline & AADT & 32.3 & 14.8 & 4.7 & 30.7 & 19.8 & 0.0 \\
\hline \multirow[t]{2}{*}{ Bus (4) } & Weight & $30.7(8.7 \%)$ & $19.3(81.0 \%)$ & $6.3(200.6 \%)$ & $29.9(32.2 \%)$ & $30.3(16.8 \%)$ & $16.7(94.0 \%)$ \\
\hline & AADT & 22.5 & 1.4 & 0.3 & 26.2 & 20.8 & 1.6 \\
\hline \multirow[t]{2}{*}{ 2-axle 6-tire Single Unit (5) } & Weight & $10.6(10.7 \%)$ & $9.2(17.8 \%)$ & $9.6(20.7 \%)$ & $10.6(29.8 \%)$ & $10.4(13.8 \%)$ & $16.7(16.0 \%)$ \\
\hline & AADT & 307.8 & 114.1 & 46.0 & 1197.8 & 1085.7 & 29.9 \\
\hline \multirow[t]{2}{*}{ 3-axle Single Unit (6) } & Weight & $23.4(11.0 \%)$ & $25.4(25.4 \%)$ & $23.1(28.7 \%)$ & $28.1(22.9 \%)$ & $30.7(10.4 \%)$ & $27.9(19.5 \%)$ \\
\hline & AADT & 30.9 & 16.2 & 10.4 & 268.0 & 243.4 & 36.3 \\
\hline \multirow[t]{2}{*}{$4^{+}$-axle Single Unit (7) } & Weight & $12.4(156.7 \%)$ & $8.0(209.0 \%)$ & $4.5(306.5 \%)$ & $36.6(61.3 \%)$ & $45.8(38.0 \%)$ & $13.2(188.7 \%)$ \\
\hline & AADT & 0.8 & 0.4 & 0.4 & 14.6 & 25.0 & 0.3 \\
\hline \multirow[t]{2}{*}{ 4-axle S. Trailer (8) } & Weight & $24.8(11.8 \%)$ & $30.2(26.7 \%)$ & $32.7(33.5 \%)$ & $28.1(26.3 \%)$ & $25.0(19.1 \%)$ & $35.0(31.3 \%)$ \\
\hline & AADT & 83.4 & 27.3 & 12.2 & 317.1 & 120.4 & 8.8 \\
\hline \multirow[t]{2}{*}{ 5-axle S. Trailer (9) } & Weight & $54.9(8.5 \%)$ & $51.1(10.7 \%)$ & $59.3(8.1 \%)$ & $59.8(8.7 \%)$ & $51.3(9.4 \%)$ & $58.0(7.4 \%)$ \\
\hline & AADT & 811.7 & 111.1 & 185.2 & 1485.0 & 398.0 & 108.6 \\
\hline \multirow[t]{2}{*}{$6^{+}$-axle S. Trailer (10) } & Weight & $59.0(10.8 \%)$ & $55.1(22.5 \%)$ & $50.6(18.7 \%)$ & $61.0(14.7 \%)$ & $55.3(12.6 \%)$ & $60.1(19.9 \%)$ \\
\hline & AADT & 49.3 & 13.2 & 30.3 & 146.2 & 163.1 & 28.5 \\
\hline \multirow[t]{2}{*}{ 5-axle M. Trailer (11) } & Weight & $51.8(11.2 \%)$ & $46.4(22.7 \%)$ & $57.4(12.9 \%)$ & $52.0(24.0 \%)$ & $29.0(46.8 \%)$ & $31.3(81.6 \%)$ \\
\hline & AADT & 53.0 & 6.0 & 15.8 & 70.9 & 5.4 & 1.6 \\
\hline \multirow[t]{2}{*}{ 6-axle M. Trailer (12) } & Weight & $55.2(10.4 \%)$ & $54.5(17.1 \%)$ & $61.8(14.6 \%)$ & $65.8(13.8 \%)$ & $67.0(21.1 \%)$ & $63.4(31.2 \%)$ \\
\hline & AADT & 65.5 & 20.5 & 30.0 & 113.6 & 15.1 & 7.0 \\
\hline \multirow[t]{2}{*}{$7^{+}$-axle M. Trailer (13) } & Weight & $76.1(9.7 \%)$ & $71.8(15.3 \%)$ & $75.0(9.3 \%)$ & $78.0(15.1 \%)$ & $84.5(9.5 \%)$ & $78.9(10.1 \%)$ \\
\hline & AADT & 135.9 & 31.6 & 85.4 & 414.2 & 180.1 & 51.8 \\
\hline \multirow[t]{2}{*}{ Unclassified (14) } & Weight & $19.0(31.2 \%)$ & $23.8(42.4 \%)$ & $20.1(61.6 \%)$ & $14.9(58.1 \%)$ & $16.5(36.4 \%)$ & $27.2(39.1 \%)$ \\
\hline & AADT & 60.0 & 20.5 & 4.3 & 95.4 & $\mathbf{3 7 . 0}$ & 6.2 \\
\hline
\end{tabular}

${ }^{*}$ Numbers in parenthesis are the associated coefficients of variation (CV) 


\section{SUMMARY REMARKS}

\section{Annual Traffic Estimates and Associated Coefficients of Variation}

The coefficients of variation associated with the overall AADT for the 21 Florida sites range from $8 \%$ to $22 \%$ (Table 5).

In general and not surprisingly, the coefficients of variation by vehicle class tended to be larger than the coefficients of variation for all the classes combined. The range of the coefficients of variation associated with AADT is the smallest for passenger cars, from $11 \%$ to $22 \%$; and the highest for six-axle multi-trailer trucks, from $93 \%$ to $1,327 \%$ (Table 6). For each classification site, higher mean daily traffic counts for a vehicle class tended to have the lower coefficients of variation. As expected, Table 6 shows that the variability of passenger cars (Classes 2 and 3 ) is much less than that of other categories. This reinforces the need to take longer classification counts than volume counts and hence supports one of the basic recommendations from the TMG. Also the data show that Classes $1,4,7,10,11,12$, and 13 have such few vehicles as to question the need to bother with these categories in the Florida sites examined. This should also be raised as a potential question for any categories with small counts at any site in any state.

Coefficients of variation for the weight per vehicle estimates are generally lower and have shorter ranges than the coefficients of variation for the ESAL per vehicle estimates (Tables 7 and 8 ). 


\subsection{Coefficients of Variation (CV) by "Day of Week"}

\subsubsection{Coefficients of Variation (CV) for AADT by "Day of Week"}

The range of the coefficients of variation for AADT by "day of week" for each of Florida's 21 sites are given in Table 9. For example, the lowest Sunday CV for AADT among the 21 sites was $4 \%$ and the highest Sunday CV among 21 sites was $18 \%$. We observe similar ranges of CV for each day of the week.

Table 9.

CV Ranges Over Days of Week for AADT Over Florida's 21 Count Sites

\begin{tabular}{|c|ccccccc|}
\hline & \multicolumn{7}{|c|}{ Days of Week } \\
Combined & Sun & Mon & Tue & Wed & Thu & Fri & Sat \\
\cline { 2 - 8 } Vehicles & $4-18 \%$ & $4-18 \%$ & $2-18 \%$ & $2-17 \%$ & $2-18 \%$ & $3-20 \%$ & $4-21 \%$ \\
\hline
\end{tabular}

\subsubsection{Coefficients of Variation (CV) for AADT by Vehicle Class by "Day of Week"}

The ranges of the coefficients of variation over the seven days of the week is the lowest for passenger cars (Class 2) and the next lowest for is other two-axle four-tire single-unit vehicles (Class 3). By far, the highest ranges exist for vehicle classes 11 (five-or-less axles, multi-trailer trucks), 12 (six-axle, multi-trailer trucks), and 13 (seven-or-more axles, multi-trailer trucks), but the absolute mean daily traffic volumes in each of these classes is quite low.

For each vehicle class at each site, we ranked mean daily traffic volume over the day of the week from the lowest $(=1)$ to the highest $(=7)$. For each vehicle class and for each day, we summed the ranks over the 8 classification sites. Then, we ranked the sums from 1 to 7 and reported the results for each vehicle class (Table 10). For example, the highest mean daily traffic volume for "three-axle, single-unit trucks" occur on Wednesday while the lowest mean daily traffic volume for this vehicle class occur on Sunday (Table 10). For this same vehicle class, the days with highest mean daily traffic volume occur Wednesday, Thursday, and Friday; while the days with lowest mean daily traffic volume tend to be Sunday, Saturday, Monday, and Tuesday. Note that the ranking for "three-axle, single-unit trucks" does not differ much from the ranking for all vehicles combined. 
In a way analogous to that described above, Table 11 gives ranks by vehicle class of coefficients of variation over the days of the week based on the 8 classification sites. For the 8 classification sites that the highest coefficients of variation for "three-axle, single-unit trucks" occur on Sunday (the day with the lowest mean daily traffic volume), while the lowest coefficient of variation for this vehicle class occur on Tuesday.

For each vehicle class collectively over the 8 classification sites, relatively high days of mean daily traffic volume are on Mondays, Tuesdays, Wednesdays, Thursdays, and Fridays; and relatively low days of traffic volume are on Saturdays and Sundays. However, the reverse seems true for associated coefficients of variation. For each class collectively over the 8 classification sites, relatively low coefficients of variation are on Mondays, Tuesdays, Wednesdays, Thursdays, and Fridays; and relatively high coefficients of variation on are Saturdays and Sundays (see Figure 1 for Site 9925 data). Lines associated with an individual vehicle class are labeled by a number that represents the specific vehicle class. For example, the line labeled AADTV1 represents the average daily AADT of Vehicle Class 1, which is motorcycle, and the line labeled AADT5 represents the average daily AADT of Vehicle Class 5, which is 2-axle 6-tire single unit truck (Table 10). Also, note that the scale is different in each plot. One finding illustrated in Figure 1 is that the higher the daily traffic volume the lower the coefficient of variation. For example, the coefficients of variation associated with the AADTs of 4-axle single unit trucks at Florida Site 9925 reach as high as $250 \%$, largely due to the infrequency of this type of vehicle - less than 50 such vehicles on a typical day. 
Table 10.

Ranks of the Mean Daily Traffic Volumes

By Vehicle Class Over the Days of the Week Based on the 8 Classification Sites

(1=lowest; $7=$ highest)

\begin{tabular}{|l|ccccccc||}
\hline \multirow{2}{*}{ Vehicle Class } & \multicolumn{7}{|c||}{ Day of Week } \\
\cline { 2 - 8 } & Sun & Mon & Tue & Wed & Thu & Fri & Sat \\
\hline (1) Motorcycles & 2 & 6 & 5 & 3 & 3 & 7 & 1 \\
(2) Passenger Cars & 1 & 3 & 4 & 5 & 6 & 7 & 2 \\
(3) Other 2 Axle, 4 Tire, S Unit & 1 & 3 & 4 & 5 & 6 & 7 & 2 \\
(4) Buses & 1 & 3 & 5 & 4 & 6 & 7 & 2 \\
(5) 2 Axle, 6 Tire, S Unit & 1 & 3 & 7 & 5 & 6 & 4 & 2 \\
(6) 3 Axle, S Unit & 1 & 3 & 4 & 7 & 6 & 5 & 2 \\
(7) 4+ Axle, S Unit & 1 & 5 & 7 & 6 & 4 & 3 & 2 \\
(8) 4- Axle, S Trailer & 1 & 3 & 6 & 4 & 5 & 7 & 2 \\
(9) 5 Axle, S Trailer & 1 & 3 & 6 & 7 & 5 & 4 & 2 \\
(10) 6+ Axle, S Trailer & 1 & 5 & 7 & 4 & 6 & 3 & 2 \\
(11) 5- Axle, M Trailers & 1 & 3 & 4 & 7 & 5 & 5 & 2 \\
(12) 6 Axle, M Trailers & 2 & 3 & 4 & 6 & 5 & 6 & 1 \\
(13) 7+ Axle, M Trailers & 1 & 5 & 4 & 7 & 3 & 6 & 2 \\
(14) Unclassified/Others & 1 & 3 & 4 & 6 & 5 & 7 & 2 \\
\hline COMBINED VEHICLES* & 1 & 3 & 4 & 5 & 6 & 7 & 2 \\
\hline
\end{tabular}

${ }^{*}$ Combined Vehicles Ranking is based on Table 4.2 of [2]. 
Table 11.

Ranks of the Coefficients of Variation for Traffic Volumes

By Vehicle Class Over the Days of the Week Based on the 8 Classification Sites (1=lowest; 7=highest)

\begin{tabular}{|c|c|c|c|c|c|c|c|c|}
\hline \multirow{2}{*}{\multicolumn{2}{|c|}{ Vehicle Class }} & \multicolumn{7}{|c|}{ Day of Week } \\
\hline & & \multirow{2}{*}{$\frac{\text { Sun }}{7}$} & \multirow{2}{*}{$\frac{\text { Mon }}{1}$} & \multirow{2}{*}{$\frac{\text { Tue }}{2}$} & \multirow{2}{*}{$\frac{\text { Wed }}{5}$} & \multirow{2}{*}{$\frac{\text { Thu }}{4}$} & \multirow{2}{*}{$\frac{\text { Fri }}{2}$} & \multirow{2}{*}{$\frac{\text { Sat }}{6}$} \\
\hline (1) & Motorcycles & & & & & & & \\
\hline (2) & Passenger Cars & 5 & 7 & 2 & 4 & 3 & 1 & 5 \\
\hline (3) & Other 2 Axle, 4 Tire, $S$ Unit & 6 & 7 & 1 & 2 & 4 & 3 & 5 \\
\hline$(4)$ & Buses & 7 & 4 & 4 & 3 & 1 & 2 & 6 \\
\hline$(5)$ & 2 Axle, 6 Tire, S Unit & 7 & 5 & 2 & 1 & 3 & 4 & 6 \\
\hline (6) & 3 Axle, S Unit & 7 & 5 & 1 & 2 & 4 & 3 & 6 \\
\hline (7) & $4+$ Axle, S Unit & 7 & 2 & 1 & 5 & 3 & 4 & 6 \\
\hline$(8)$ & 4- Axle, S Trailer & 7 & 5 & 1 & 2 & 4 & 2 & 6 \\
\hline$(9)$ & 5 Axle, $S$ Trailer & 5 & 5 & 2 & 3 & 4 & 1 & 7 \\
\hline$(10)$ & $6+$ Axle, $S$ Trailer & 7 & 4 & 1 & 2 & 3 & 5 & 6 \\
\hline (11) & 5- Axle, M Trailers & 7 & 5 & 2 & 3 & 1 & 3 & 6 \\
\hline (12) & 6 Axle, $M$ Trailers & 5 & 2 & 3 & 3 & 1 & 6 & 7 \\
\hline (13) & $7+$ Axle, $M$ Trailers & 7 & 2 & 5 & 3 & 4 & 1 & 6 \\
\hline$(14)$ & Unclassified/Others & 7 & 6 & 2 & 4 & 3 & 1 & 5 \\
\hline \multicolumn{2}{|c|}{ COMBINED VEHICLES* } & 6 & 7 & 1 & 4 & 3 & 2 & 5 \\
\hline
\end{tabular}

${ }^{*}$ Combined Vehicles Ranking is based on Table 4.2 of [2]. 

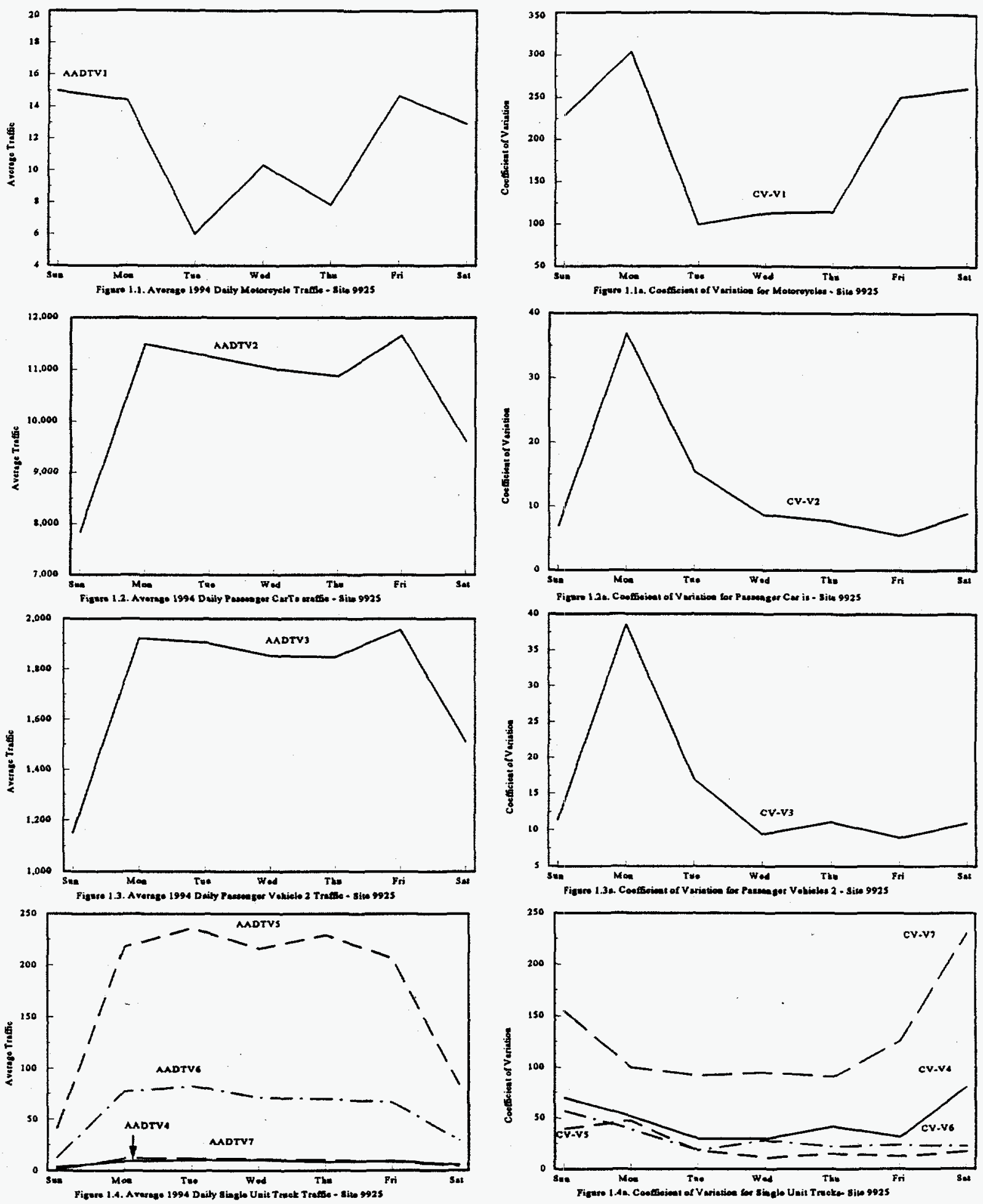

Fig. 1. Vehicle Class Mean Daily Traffic Counts and Coefficients of Variation by Day of Week for Florida Classification Site 9925 

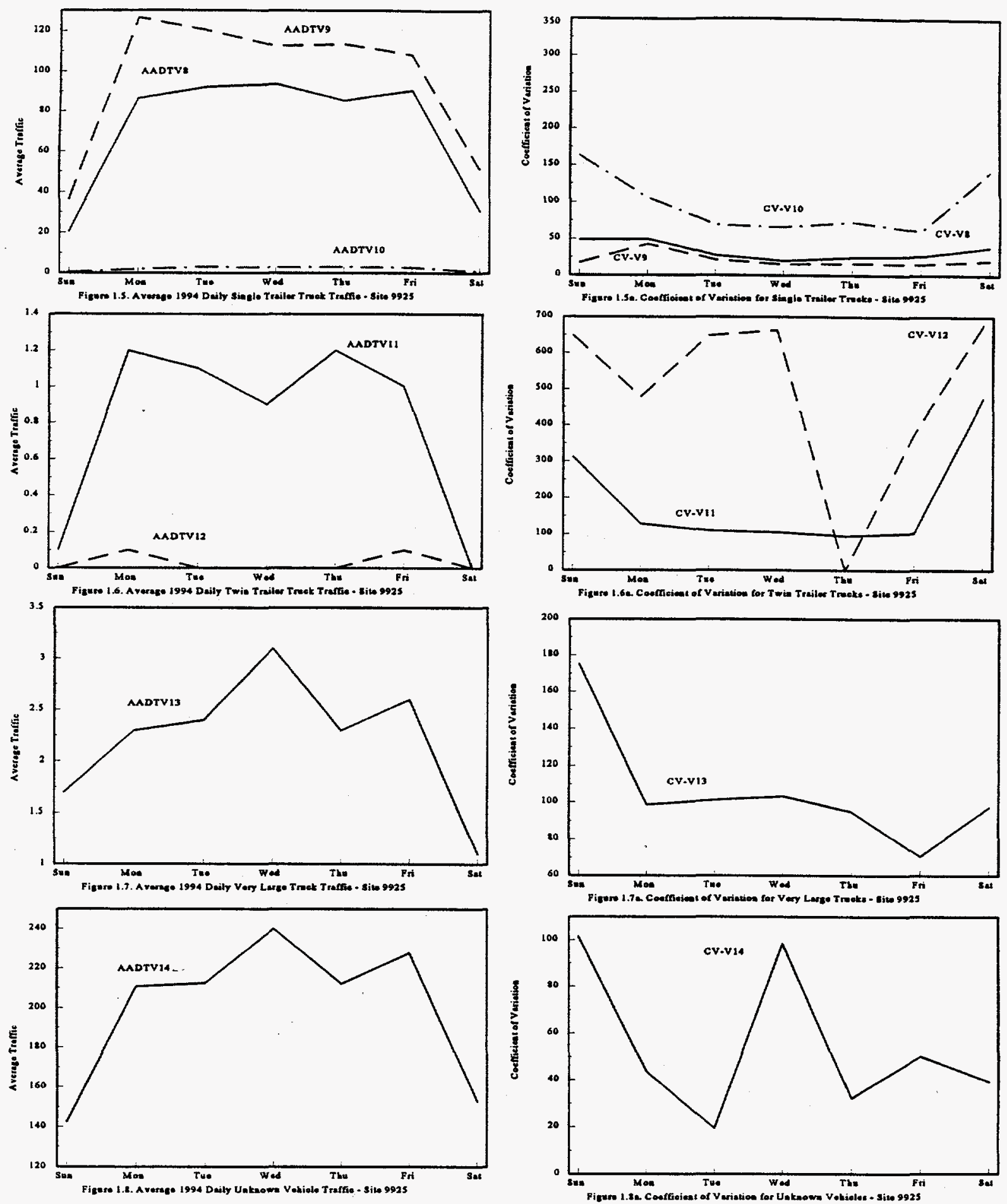

Fig. 1. (continued) 


\subsubsection{Coefficients of Variation (CV) for Daily ESAL per Vehicle Ranges Over "Days of Week"}

The lowest and shortest ranges of the "day of week" coefficients of variation for daily ESAL per vehicle that range over the seven days of the week are for 5-axle single trailers (Vehicle Class 9) (Table 12). Relatively low and short ranges are also observed for Classes 10 (6-or-more axle, single trailers), 12 (6-axle, multi trailers), and 13 (2-or-more axle, multi trailers). The highest and longest ranges appear to exist for 4-or-more axles, single-unit trucks (Classes 7) and for unclassified vehicles (Class 14).

Table 12.

CV Ranges over Days of Week for "ESAL" for Each Vehicle Class at Each of the 6 Washington Weigh-In-Motion Sites

\begin{tabular}{||l|cccccc||}
\hline \multirow{2}{*}{ Vehicle Class } & \multicolumn{7}{|c|}{ Weigh-In-Motion Sites } \\
\cline { 2 - 7 } & $\mathbf{P 1 0}$ & P05 & P17 & P29 & P19 & P07 \\
\hline (3) Other 2 Axle, 4 Tire, S Unit & $30-53$ & $61-235$ & $69-253$ & $268-555$ & $43-67$ & \\
(4) Buses & $32-42$ & $118-168$ & $208-393$ & $37-60$ & $27-57$ & $78-224$ \\
(5) 2 Axle, 6 Tire, S Unit & $26-35$ & $54-137$ & $84-260$ & $23-196$ & $23-40$ & $31-157$ \\
(6) 3 Axle, S Unit & $34-57$ & $62-194$ & $45-163$ & $27-63$ & $22-49$ & $33-85$ \\
(7) $4^{+}$Axle, S Unit & $181-343$ & $213-707$ & $325-714$ & $55-190$ & $29-237$ & $156-672$ \\
(8) 4- Axle, S Trailer & $23-45$ & $55-110$ & $58-151$ & $22-116$ & $24-64$ & $35-120$ \\
(9) 5 Axle, S Trailer & $28-32$ & $34-43$ & $21-28$ & $24-28$ & $28-43$ & $22-27$ \\
(10) 6+ Axle, S Trailer & $29-40$ & $58-95$ & $41-70$ & $29-38$ & $29-61$ & $25-87$ \\
(11) 5- Axle, M Trailers & $28-38$ & $45-97$ & $27-42$ & $26-50$ & $82-209$ & $118-287$ \\
(12) 6 Axle, M Trailers & $34-46$ & $44-75$ & $32-60$ & $29-39$ & $29-71$ & $41-129$ \\
(13) 7+ Axle, M Trailers & $31-34$ & $45-55$ & $22-36$ & $26-40$ & $24-31$ & $20-34$ \\
(14) Unclassified Vehicles & $79-346$ & $65-187$ & $142-341$ & $91-137$ & $44-150$ & $69-242$ \\
\hline
\end{tabular}




\subsubsection{Coefficients of Variation (CV) for Daily Weight per Vehicle Ranges Over "Days of Week"}

The lowest and shortest ranges of the "day of week" coefficients of variation for daily weight estimates exist for Vehicle Class 9, 5-axle, single trailers (Table 13). By far, the highest and longest ranges appear to exist for four-or-more axles, single unit trucks (Class 7).

Table 13.

CV Ranges over Days of Week for "Weight" for Each Vehicle Class at Each of the 6 Weigh-In-Motion Sites from Washington

\begin{tabular}{||l|cccccc||}
\hline \multirow{2}{*}{ Vehicle Class } & \multicolumn{7}{|c|}{ Weigh-In-Motion Sites } \\
\cline { 2 - 7 } & P10 & P05 & P17 & P29 & P19 & P07 \\
\hline (3) Other 2 Axle, 4 Tire, S Unit & $8-12$ & $18-31$ & $27-36$ & $57-91$ & $8-18$ & \\
(4) Buses & $8-9$ & $51-113$ & $151-233$ & $21-47$ & $7-29$ & $59-163$ \\
(5) 2 Axle, 6 Tire, S Unit & $8-11$ & $14-21$ & $14-26$ & $7-70$ & $7-10$ & $9-25$ \\
(6) 3 Axle, S Unit & $8-14$ & $13-37$ & $11-51$ & $8-34$ & $6-12$ & $7-43$ \\
(7) 4+ Axle, S Unit & $120-202$ & $158-527$ & $247-714$ & $37-122$ & $8-175$ & $129-452$ \\
(8) 4- Axle, S Trailer & $7-16$ & $15-28$ & $20-55$ & $6-50$ & $6-15$ & $14-49$ \\
(9) 5 Axle, S Trailer & $7-9$ & $9-12$ & $6-9$ & $6-13$ & $8-11$ & $7-8$ \\
(10) 6+ Axle, S Trailer & $9-13$ & $15-36$ & $15-27$ & $9-17$ & $10-19$ & $8-39$ \\
(11) 5- Axle, M Trailers & $6-18$ & $16-32$ & $9-20$ & $11-39$ & $34-82$ & $52-225$ \\
(12) 6 Axie, M Trailers & $9-13$ & $14-22$ & $10-24$ & $8-22$ & $10-45$ & $12-58$ \\
(13) 7+ Axle, M Trailers & $9-10$ & $10-22$ & $7-10$ & $7-29$ & $8-11$ & $6-16$ \\
(14) Unclassified Vehicles & $21-36$ & $32-63$ & $38-70$ & $34-74$ & $22-36$ & $17-60$ \\
\hline
\end{tabular}




\section{SUMMARY REMARKS \\ Annual Traffic Estimates and Coefficients of Variation by "Day of Week"}

In general, high coefficients of variation tend to occur with vehicle classes that have extremely low mean daily traffic volumes (Figure 2 ).

For "day of week", high average daily traffic counts appear to have low coefficients of variation. The lowest variability in daily counts seems to occur on Tuesdays, Wednesdays, Thursdays, and Fridays. As a result, the variability among the weekend daily traffic counts seems to be higher than the variability among the weekday daily traffic counts.

Similarly, the larger coefficients of variation for different vehicle classes tend to occur on Sundays, Mondays, and Saturdays; while the lower coefficients of variation tend to occur on Tuesday through Friday. The lowest CV ranges associated with AADT exist for passenger cars and the highest range exist for multi-trailer trucks. There are statistically significant $(\alpha=0.05)$ differences between means (and standard deviations) for weekend days and weekdays at each classification site for each vehicle class.

The "day of week" coefficients of variation for weight are generally lower and have shorter ranges than those for ESAL. The low coefficients of variation for ESAL and weight are for Class 9 (5-axle single-trailer truck) which is generally the class with the highest daily proportion of vehicles. For both ESAL and weight estimates, there are statistically significant differences between mean values for weekdays and weekend days at each weigh-in-motion site for each vehicle class.

For more details on the statistical differences $(\alpha=.05)$ between means (and standard deviations) for weekdays and weekend days that were observed for the following data, see the indicated reports:

$$
\begin{array}{rcl}
\text { count data } & : & \text { Chapter } 5 \text { of Task II Report, } \\
\text { classification data } & : & \text { Chapter } 6 \text { of Task V Report, or } \\
\text { ESAL data/weight data } & : & \text { Chapter } 6 \text { of Task VIII Report. }
\end{array}
$$

These observed differences between weekend day data and weekday data confirm the need that annualization by day of week factors, or at least by weekday and weekend factors, is a necessity. 

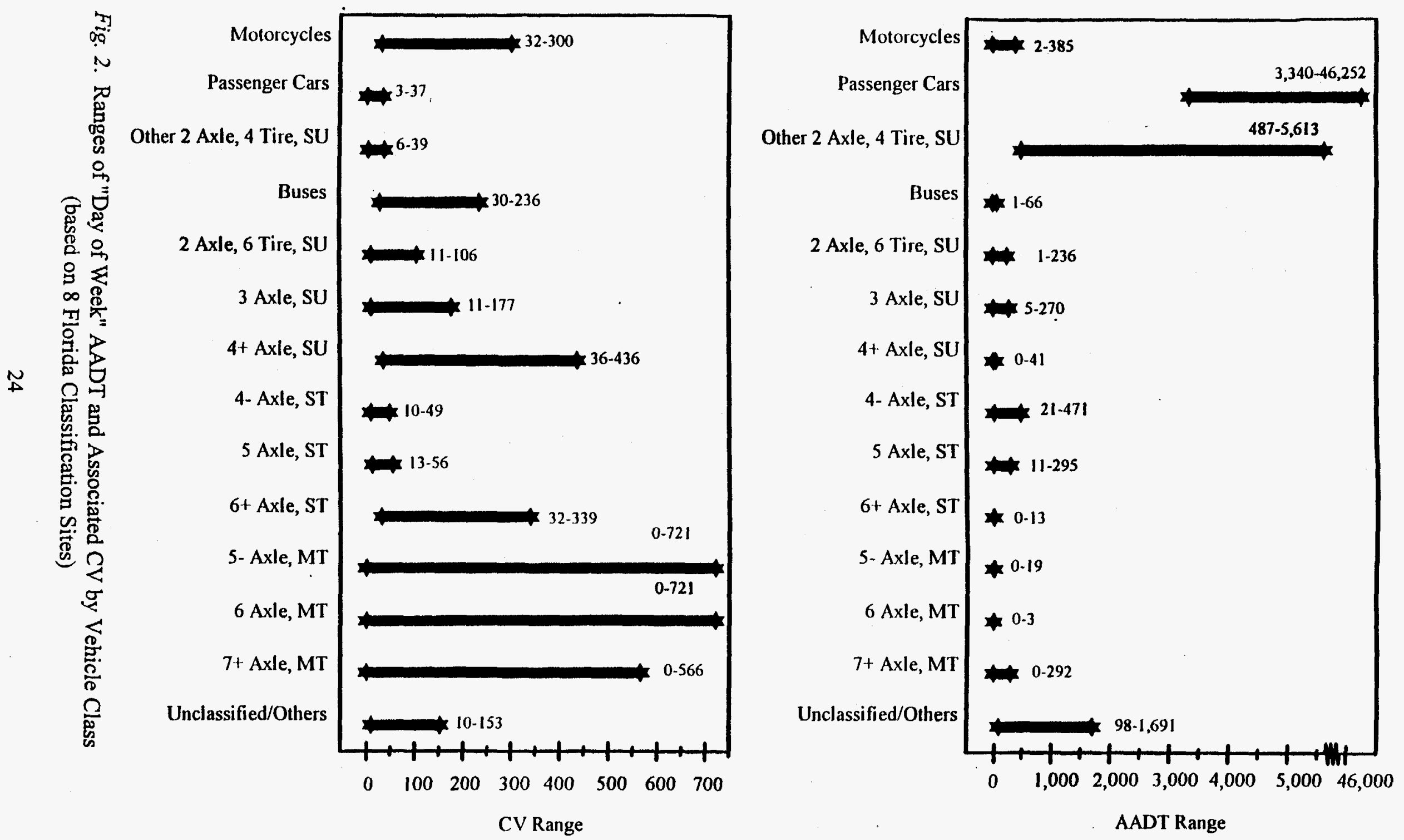
3.4 Coefficients of Variation (CV) by "Month of Year"

\subsubsection{Coefficients of Variation (CV) for AADT by "Month of Year"}

We observe similar ranges of CV for each month of the year (Table 14) and slightly higher CV's for the month of the year than for the day of the week.

Table 14.

CV Ranges Over Months of Year

for AADT over Florida's 21 Count Sites (\%)

\begin{tabular}{|c|cccccccccccc|}
\hline & \multicolumn{10}{|c|}{ Month of Year } \\
All & Jan & Feb & Mar & Apr & May & Jun & Jul & Aug & Sep & Oct & Nov & Dec \\
\cline { 2 - 11 } \\
Vehicles & $6-25$ & $6-23$ & $6-20$ & $7-24$ & $5-26$ & $5-19$ & $6-25$ & $5-21$ & $2-24$ & $7-22$ & $9-25$ & $8-27$ \\
\hline
\end{tabular}

\subsubsection{Coefficients of Variation (CV) for AADT by Vehicle Class by "Month of Year"}

The lowest and shortest ranges of the "month-of-the- year" coefficients of variation are for passenger cars (Class 2) and the next lowest ranges are for other 2-axle, 4-tire, single-unit trucks (Class 3 ). Also as in Table 15, the highest and longest ranges are for multi-trailer trucks (Classes 11,12 , and 13), mainly because of the low mean daily traffic volumes of these vehicles.

\subsubsection{Coefficients of Variation (CV) for Daily ESAL per Vehicle by Vehicle Class by "Month of Year"}

For the 6 weigh-in-motion sites, the lowest and shortest ranges of the "month-of-the-year" coefficients of variation for daily ESAL per vehicle exist for 5-axle, single-trailer trucks (Class 9) and 7-or-more axles, multi-trailer trucks (Class 13) (Table 16). As in Table 12 for "day-of- week" for ESAL, we observe the highest and longest ranges for 4-or-more axle, single-unit trucks and unclassified trucks. 
Table 15.

CV Ranges Over Months of Year for Each Vehicle Class at Each of the 8 Classification Sites from Florida

\begin{tabular}{|c|c|c|c|c|c|c|c|c|}
\hline \multirow[b]{2}{*}{ Vehicle Class } & \multicolumn{8}{|c|}{ Classification Sites } \\
\hline & 9925 & 170 & 114 & 177 & 113 & 197 & 246 & 175 \\
\hline (1) Motorcycles & $53-287$ & $33-108$ & $0-64$ & $43-113$ & $26-95$ & $44-77$ & $42-95$ & $38-108$ \\
\hline (2) Passenger Cars & $10-48$ & $9-13$ & $0-16$ & $12-16$ & $10-16$ & $1-17$ & $7-12$ & $19-26$ \\
\hline (3) Other 2 Axle, 4 Tire, S Unit & $15-55$ & $16-30$ & $0-30$ & $25-43$ & $19-26$ & $4-34$ & $17-33$ & $27-36$ \\
\hline (4) Buses & $35-65$ & $61-109$ & $0-163$ & $26-61$ & $49-140$ & $5-84$ & $40-71$ & $25-53$ \\
\hline (5) 2 Axle, 6 Tire, S Unit & $38-75$ & $49-62$ & $0-79$ & $49-76$ & $45-67$ & $5-65$ & $38-69$ & $45-59$ \\
\hline (6) 3 Axle, S Unit & $39-75$ & $26-71$ & $0-63$ & $40-94$ & $35-51$ & $20-50$ & $54-63$ & $48-113$ \\
\hline (7) $4+$ Axle, S Unit & $51-194$ & $58-184$ & $0-208$ & $48-75$ & $65-127$ & $67-105$ & $112-200$ & $67-175$ \\
\hline (8) 4-Axle, S Trailer & $35-83$ & $18-33$ & $0-36$ & $30-46$ & $27-36$ & $11-45$ & $21-42$ & $33-52$ \\
\hline (9) 5 Axle, S Trailer & $29-70$ & $36-47$ & $0-52$ & $44-74$ & 39.49 & $5-56$ & $44-53$ & $21-30$ \\
\hline (10) 6+ Axle, S Trailer & $66-103$ & $58-127$ & $0-78$ & $54-83$ & $64-122$ & $48-87$ & $97-134$ & $70-145$ \\
\hline (11) 5-Axle, M Trailers & $58-288$ & 0.556 & $0-539$ & $41-150$ & $111-280$ & $35-67$ & $0-548$ & $78-177$ \\
\hline (12) 6 Axle, M Trailers & $0-557$ & $0-548$ & $0-305$ & $63-164$ & $0-424$ & $63-131$ & $0-548$ & $79-195$ \\
\hline (13) 7+ Axle, M Trailers & $60-156$ & $48-374$ & $0-409$ & $36-176$ & $65-154$ & $0-331$ & $135-421$ & $99-328$ \\
\hline (14) Unclassified/Others & $23-123$ & $21-38$ & $0-43$ & $28-62$ & $17-23$ & $4-36$ & $20-38$ & $42-181$ \\
\hline
\end{tabular}

Table 16.

CV Ranges over Months of Year for "ESAL" for Each Vehicle Class at Each of the 6 Weigh-In-Motion Sites from Washington

\begin{tabular}{|c|c|c|c|c|c|c|c|}
\hline \multirow{2}{*}{\multicolumn{2}{|c|}{ Vehicle Class }} & \multicolumn{6}{|c|}{ Weigh-In-Motion Sites } \\
\hline & & \multirow{2}{*}{$\frac{P 10}{15-61}$} & \multirow{2}{*}{$\frac{\text { P05 }}{40-288}$} & \multirow{2}{*}{$\frac{P 17}{41-315}$} & \multirow{2}{*}{$\frac{\text { P29 }}{31-469}$} & \multirow{2}{*}{$\frac{P 19}{31-66}$} & \multirow[t]{2}{*}{ P07 } \\
\hline$(3)$ & Other 2 Axle, 4 Tire, $S$ Unit & & & & & & \\
\hline$(4)$ & Buses & $12-32$ & $108-179$ & $178-557$ & $21-67$ & $22-49$ & $50-254$ \\
\hline$(5)$ & 2 Axle, 6 Tire, $S$ Unit & $22-37$ & $40-98$ & $43-156$ & 29.174 & $33-49$ & $32-115$ \\
\hline$(6)$ & 3 Axle, S Unit & $27-47$ & $56-119$ & $48-98$ & $17-51$ & $18-32$ & $35-94$ \\
\hline (7) & $4^{+}$Axle, S Unit & $158-394$ & $169-548$ & $178-548$ & $60-144$ & $28-63$ & $138-453$ \\
\hline$(8)$ & $4^{*}$ Axle, S Trailer & $18-30$ & $45-78$ & $55-100$ & $27-69$ & $29-53$ & $46-83$ \\
\hline$(9)$ & 5 Axle, S Trailer & $8-24$ & $16-54$ & $11-34$ & 7.29 & $12-32$ & $13-32$ \\
\hline$(10)$ & $6^{+}$Axle, S Trailer & $16-32$ & $42-90$ & $19-61$ & $11-35$ & $19-33$ & $24-71$ \\
\hline (11) & $5^{-}$Axle, M Trailers & $15-38$ & $41-128$ & $17-42$ & $19-47$ & $80-199$ & $95-277$ \\
\hline$(12)$ & 6 Axle, M Trailers & $11-41$ & $28-66$ & $20-55$ & $11-35$ & $26-52$ & $48-86$ \\
\hline$(13)$ & $7^{+}$Axle, M Trailers & $8-24$ & $21-62$ & $16-45$ & $7-29$ & $8-33$ & $15-30$ \\
\hline (14) & Unclassified Vehicles & $32-338$ & $51-114$ & $82-303$ & $47-131$ & $55-80$ & $76-175$ \\
\hline
\end{tabular}




\subsubsection{Coefficients of Variation (CV) for Average Daily Weight per Vehicle by Vehicle Class by "Month of Year"}

For the 6 weigh-in-motion sites, ranges over "month-of-the-year" coefficients of variation for weight are shown in Table 17. We continue to observe that the lowest and shortest ranges appear to occur for 5-axle, single-trailer trucks (Class 9) and that the highest and longest ranges appear to exist for 4-or-more axles, single-trailer trucks (Class 7).

Table 17.

CV Ranges over Months of Year for "Weight" for Each Vehicle Class at Each of the 6 Weigh-In-Motion Sites from Washington

\begin{tabular}{||l|cccccc||}
\hline \multirow{2}{*}{ Vehicle Class } & \multicolumn{7}{|c|}{ Weigh-In-Motion Sites } \\
\cline { 2 - 7 } & P10 & P05 & P17 & P29 & P19 & P07 \\
\hline (3) Other 2 Axle, 4 Tire, S Unit & $4-11$ & $11-46$ & $11-52$ & $20-99$ & $6-21$ \\
(4) Buses & $3-8$ & $66-116$ & $144-557$ & $5-59$ & $6-35$ & $36-237$ \\
(5) 2 Axle, 6 Tire, S Unit & $5-11$ & $9-21$ & $9-28$ & $6-80$ & $10-15$ & $8-28$ \\
(6) 3 Axle, S Unit & $6-12$ & $15-34$ & $15-42$ & $6-42$ & $6-11$ & $9-36$ \\
(7) $4^{+}$Axle, S Unit & $116-247$ & $140-504$ & $144-548$ & $36-109$ & $20-47$ & $126-385$ \\
(8) 4- Axle, S Trailer & $6-12$ & $17-31$ & $21-40$ & $15-49$ & $12-22$ & $21-43$ \\
(9) 5 Axle, S Trailer & $3-7$ & $5-23$ & $5-12$ & $2-17$ & $4-8$ & $4-8$ \\
(10) 6 Axle, S Trailer & $5-10$ & $15-31$ & $7-24$ & $3-29$ & $6-14$ & $7-32$ \\
(11) 5- Axle, M Trailers & $5-21$ & $13-35$ & $7-22$ & $10-41$ & $35-78$ & $58-107$ \\
(12) 6 Axle, M Trailers & $3-10$ & $7-24$ & $5-24$ & $3-23$ & $11-41$ & $25-37$ \\
(13) 7+ Axle, M Trailers & $3-7$ & $7-23$ & $5-15$ & $3-22$ & $3-10$ & $4-20$ \\
(14) Unclassified Vehicles & $9-46$ & $16-42$ & $33-86$ & $12-81$ & $25-45$ & $24-58$ \\
\hline \hline
\end{tabular}




\section{SUMMARY REMARKS \\ Annual Traffic Estimates and \\ Associated Coefficients of Variation by "Month of the Year"}

For the different vehicle classes, the larger coefficients of variation tend to occur during days in January and July, while the lower coefficients of variation tend to occur during days in March and April. Again, the lowest and shortest ranges of the coefficients of variation that range over the twelve months of the year are for passenger cars, followed by those for 2-axle, 4-tire, single-unit trucks. Similar to the "day-of-week" CV's, the highest and longest ranges are for multi-trailer trucks.

Monthly variability for ESAL estimate is the smallest for 5-axle single-trailer trucks and the greatest for 4-or-more axles, single-trailer trucks and unclassified vehicles. Similar results are observed for monthly variability of weight estimate. The level of the coefficients of variation for "day-of-week" is about the same as the level of the coefficients of variation for "month-of-the-year" for both ESAL estimates and weight estimates.

\subsection{Daily Vehicle Mix}

Averaging over the 8 classification sites, we obtain the following rankings for the average daily traffic percent mix for 1994 at each classification site (Table 18). (All percents are rounded). Figure 3 presents a graphical example of the count distribution of all vehicle types combined and the class empirical distribution for four vehicle types. Figure 3 shows that the distribution of daily traffic can differ greatly among the vehicle types at a site. For example for Site 9925 , the distribution of daily motorcycle traffic (Class 1) is much less variable from day to day than the distribution of daily bus traffic (Class 4 ).

The occurrence of a multi-trailer vehicle on any day is rare. At almost every one of the 8 classification sites, the level of unclassified/other vehicles is quite high relative to what is captured in other vehicle classes. The large percentage of vehicles being unclassified (Class 14) may signal some cause for concern for the reported counts in the other vehicle classes. It may also signal the need to consider decreasing the number of classes until technology can be improved to distinguish better between similar types of vehicles. This decrease in the number of classes may also lead to a significant decrease in the level of unclassified. One such grouping is proposed in Table 19. 
Table 18.

1994 Daily Vehicle Mix Based on Florida's 8 Classification Sites

\begin{tabular}{lll} 
& Percent & Vehicle Class \\
\hline Highest Ranked Class & 83.39 & (2) Passenger Cars \\
& 11.39 & (3) Other 2 Axle, 4 Tire, S Unit Vehicles \\
2.09 & (14) Unclassified/Others \\
0.99 & (8) 4- Axle, S Trailer Trucks \\
0.64 & (9) 5 Axle, S Trailer Trucks \\
& 0.55 & (6) 3 Axle, S Unit Trucks \\
& 0.38 & (5) 2 Axle, 6 Tire, S Unit Trucks \\
& 0.21 & (1) Motorcycles \\
& 0.15 & (13) $7^{+}$Axle, M Trailers Trucks \\
& 0.11 & (4) Buses \\
& 0.06 & (7) $4^{+}$Axle, S Unit Trucks \\
& 0.03 & (10) 6 Axle, S Trailer Trucks \\
& 0.01 & (11) 5- Axle, M Trailers Trucks \\
& 0.00 & (12) 6 Axle, M Trailers Trucks
\end{tabular}

Total $\quad 100.00 \%$

Table 19.

Potential Grouping Scheme of Vehicles

\begin{tabular}{|c|c|}
\hline Potential Group Class & Vehicle Classes \\
\hline \multirow[t]{2}{*}{ G1 Passenger Vehicles -1} & 2 Passenger Cars \\
\hline & 3 Other 2 Axle, 4 Tire, Single Unit \\
\hline \multirow[t]{4}{*}{ G2 Single-Unit Trucks } & 4 Buses \\
\hline & 52 Axle, 6 Tire, Single Unit \\
\hline & 63 Axle, Single Unit \\
\hline & $74^{+}$Axle, Single Unit \\
\hline \multirow[t]{3}{*}{ G3 Single-Trailer Trucks } & $84^{-}$Axle, Single Trailer \\
\hline & 95 Axle, Single Trailer \\
\hline & $106^{+}$Axle, Single Trailer \\
\hline \multirow[t]{2}{*}{ G4 Multi-Trailer Trucks } & 115 Axle, Multi-Trailer \\
\hline & 126 Axle, Multi-Trailer \\
\hline G5 Unknown Vehicle & $\begin{array}{l}14 \text { Unclassified/Other (includes Vehicle } \\
\text { Classes } 1 \text { and 13) }\end{array}$ \\
\hline
\end{tabular}



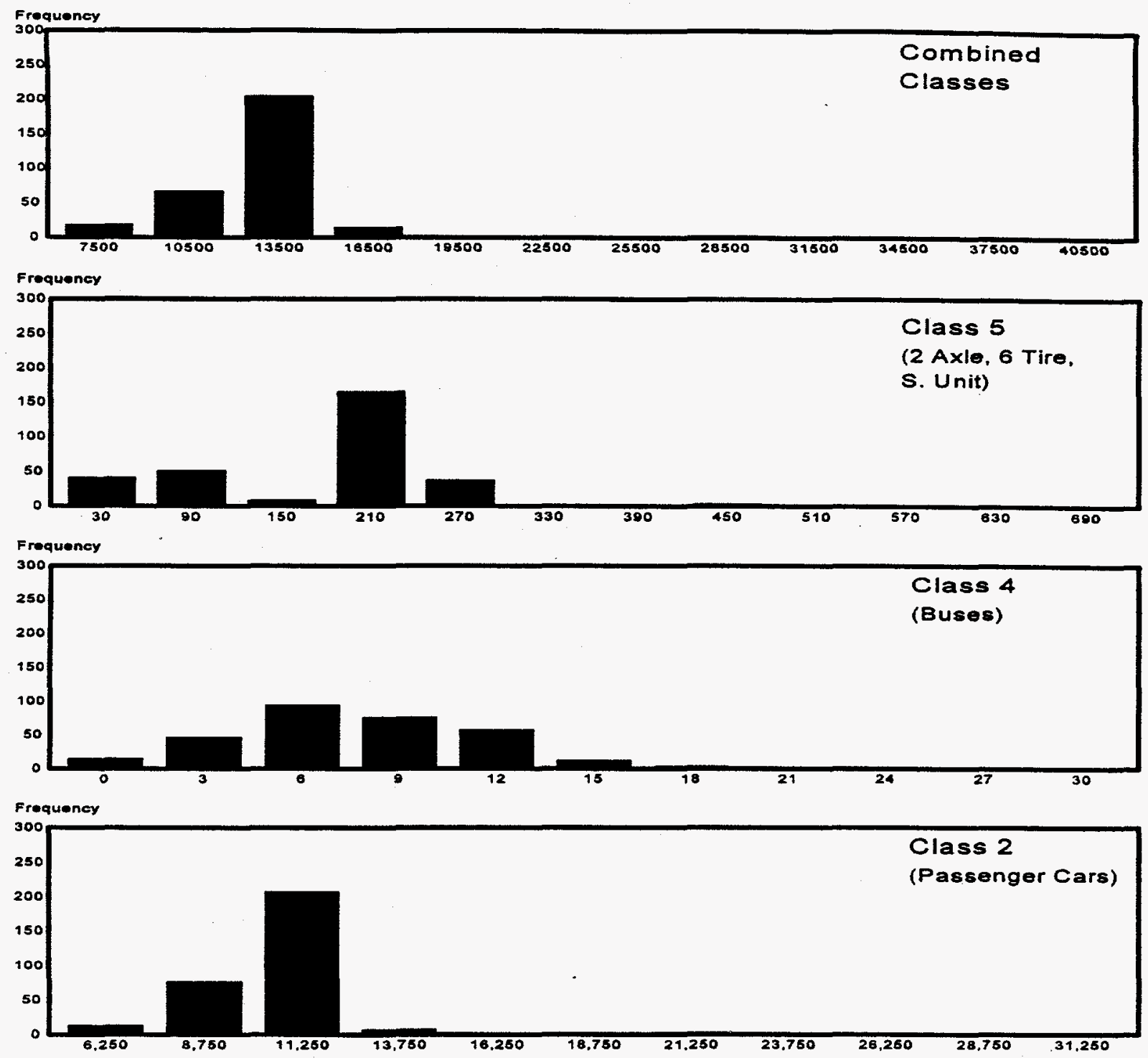

Frequency

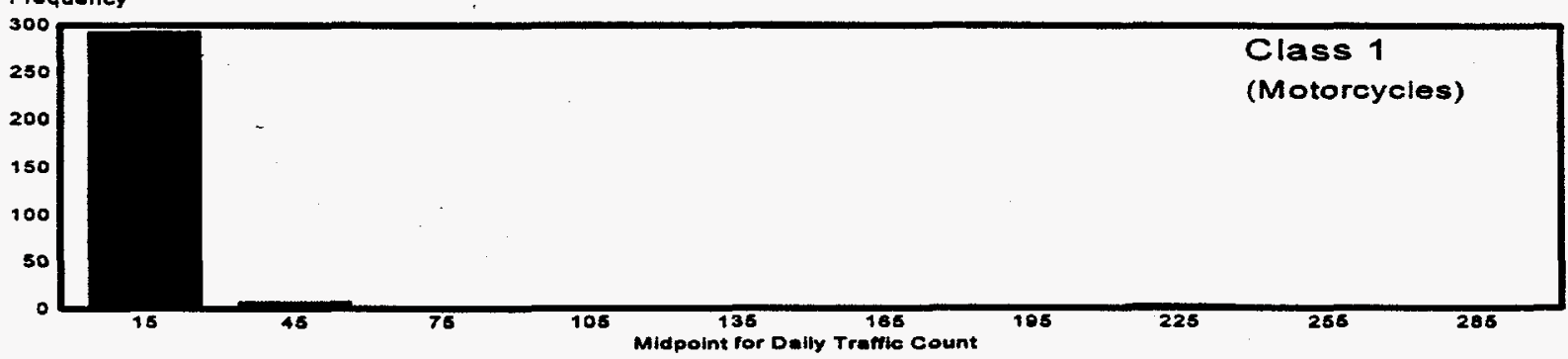

Fig. 3. Example of Combined and Class Empirical Distributions of 1994 Daily Traffic Counts for Classification Site 9925 


\subsection{Examination of Five Different Methods for Computing Annual Traffic Estimates}

\subsubsection{Five Methods for Computing Annual Traffic Estimates}

For a given road segment or a site on a given road segment, the aim of annual average daily traffic (AADT) is to characterize "...typical daily traffic (count) on (the) road segment for all days of the week, Sunday through Saturday, over the period of one year." [5] Depending on the amount and quality of available data, it appears that there are several methods to compute a quantity to pursue this aim. We compared the following five different methods of computing "typical" daily traffic volume, volume by vehicle class, and average daily ESAL and weight per vehicle:

Method 1: Average of All Days (Standard Method).

Method 2: Average of "Monthly" Averages.

Method 3: Average of "Day of Week" Averages.

Method 4: Average of "Monthly" and "Day of Week" Averages (AASHTO Method).

Method 5: Weighted Average of Average of Monthly "Weekday" and "Weekend Day" Averages.

It is assumed that Methods 2 through 5 are proposed to compensate for various patterns of missing data. Detailed steps for each method are described in [2], [3] and [4]. A tool called the maximum ratio is used to determine how close these five estimates are to each other, and how close this set of five estimates is to the true unknown value of the parameter (in our case, AADT, daily ESAL or weight per vehicle) [6].

For illustration purpose, 1994 AADTs for 21 Florida count sites that are estimated using the aforementioned five methods are given in Table 20. 
Table 20.

A Comparison AADT Computed Estimates by the Five Different Methods

\begin{tabular}{|c|c|c|c|c|c|c|c|c|c|c|c|c|c|c|c|c|c|c|}
\hline \multirow{2}{*}{$\begin{array}{l}\text { Func } \\
\text { Class }\end{array}$} & \multirow[b]{2}{*}{ Site } & \multirow{2}{*}{$\begin{array}{c}\text { No. } \\
\text { of } \\
\text { Days }\end{array}$} & \multirow{2}{*}{$\begin{array}{c}\text { No. of } \\
\text { Weekdays }\end{array}$} & \multirow{2}{*}{$\begin{array}{c}\text { No. of } \\
\text { Weekend } \\
\text { Days } \\
\end{array}$} & \multicolumn{7}{|c|}{ Number of } & \multirow{2}{*}{$\begin{array}{c}\text { No. of } \\
\text { Mos }\end{array}$} & \multicolumn{5}{|c|}{ AADT - Methods } & \multirow{2}{*}{$\begin{array}{c}\text { How Close Are } \\
\text { Methods }\end{array}$} \\
\hline & & & & & Sun & Mon & Tue & Wed & Thu & Fri & Sat & & 1 & 2 & 3 & 4 & 5 & \\
\hline 01 & 119 & 212 & 153 & 59 & 28 & 31 & 30 & 31 & 33 & 28 & 31 & 10 & 30,180 & 29,592 & 30,282 & 29,587 & 29,613 & $2.35 \%$ \\
\hline 02 & 223 & 231 & 160 & 71 & 36 & 30 & 35 & 32 & 29 & 34 & 35 & 12 & 4,474 & 4,427 & 4,479 & 4,492 & 4,439 & $1.47 \%$ \\
\hline 02 & 65 & 322 & 227 & 95 & 47 & 44 & 46 & 48 & 45 & 44 & 48 & 12 & 7,382 & 7,375 & 7,383 & 7,385 & 7,373 & $0.16 \%$ \\
\hline 02 & 9925 & 308 & 219 & 89 & 43 & 42 & 42 & 44 & 46 & 45 & 46 & 12 & 12,661 & 12,670 & 12,654 & 12,653 & 12,672 & $0.15 \%$ \\
\hline 02 & 104 & 347 & 248 & 99 & 48 & 50 & 50 & 50 & 47 & 51 & 51 & 12 & 22,098 & 22,122 & 22,084 & 22,118 & 22,139 & $0.25 \%$ \\
\hline 02 & 118 & 345 & 246 & 99 & 48 & 48 & 48 & 50 & 50 & 50 & 51 & 12 & 22,262 & 22,269 & 22,238 & 22,234 & 22,281 & $0.21 \%$ \\
\hline 06 & 170 & 353 & 253 & 100 & 48 & 49 & 50 & 52 & 51 & 51 & 52 & 12 & 5,284 & 5,284 & 5,275 & 5,277 & 5,283 & $0.17 \%$ \\
\hline 07 & 136 & 263 & 185 & 78 & 40 & 39 & 40 & 37 & 32 & 37 & 38 & 11 & 6,336 & 6,294 & 6,372 & 6,329 & 6,314 & $1.24 \%$ \\
\hline 11 & 133 & 283 & 201 & 82 & 41 & 43 & 40 & 41 & 38 & 39 & 41 & 10 & 28,026 & 28,058 & 28,062 & 28,097 & 28,085 & $0.25 \%$ \\
\hline 11 & 179 & 210 & 144 & 66 & 33 & 30 & 29 & 29 & 32 & 24 & 33 & 12 & 54,599 & 54,259 & 54,801 & 54,432 & 54,154 & $1.19 \%$ \\
\hline 11 & 130 & 341 & 244 & 97 & 48 & 49 & 49 & 46 & 52 & 48 & 49 & 12 & 110,865 & 110,819 & 110,846 & 110,677 & 110,781 & $0.17 \%$ \\
\hline 11 & 196 & 252 & 177 & 75 & 37 & 38 & 34 & 38 & 33 & 34 & 38 & 10 & 154,304 & 154,480 & 154,764 & 154,899 & 155,022 & $0.47 \%$ \\
\hline 12 & 204 & 212 & 151 & 61 & 30 & 32 & 32 & 31 & 27 & 29 & 31 & 9 & 28,294 & 28,047 & 28,354 & 28,131 & 28,046 & $1.10 \%$ \\
\hline 14 & 114 & 267 & 192 & 75 & 38 & 40 & 40 & 37 & 39 & 36 & 37 & 12 & 14,436 & 14,695 & 14,437 & 14,581 & 14,578 & $1.80 \%$ \\
\hline 14 & 177 & 333 & 235 & 98 & 48 & 48 & 46 & 47 & 45 & 49 & 50 & 12 & 33,290 & 33,428 & 33,341 & 33,486 & 33,524 & $0.70 \%$ \\
\hline 14 & 102 & 278 & 200 & 78 & 39 & 40 & 41 & 42 & 40 & 37 & 39 & 10 & 40,753 & 40,737 & 40,775 & 40,768 & 40,708 & $0.17 \%$ \\
\hline 14 & 154 & 220 & 154 & 66 & 33 & 31 & 31 & 32 & 26 & 34 & 33 & 11 & 44,030 & 43,851 & 44,143 & 43,923 & 44,265 & $0.95 \%$ \\
\hline 14 & 113 & 326 & 229 & 97 & 47 & 47 & 46 & 47 & 41 & 48 & 50 & 12 & 45,825 & 45,793 & 45,900 & 45,874 & 45,943 & $0.33 \%$ \\
\hline 14 & 197 & 212 & 151 & 61 & 32 & 29 & 30 & 31 & 32 & 29 & 29 & 9 & 47,270 & 47,716 & 47,374 & 47,412 & 47,325 & $0.94 \%$ \\
\hline 16 & 246 & 278 & 197 & 81 & 39 & 40 & 40 & 41 & 36 & 40 & 42 & 10 & 7,681 & 7,706 & 7,686 & 7,710 & 7,713 & $0.41 \%$ \\
\hline 16 & 175 & 342 & 244 & 98 & 48 & 49 & 47 & 48 & 50 & 50 & 50 & 12 & 39,920 & 39,922 & 39,905 & 39,891 & 39,945 & $0.14 \%$ \\
\hline
\end{tabular}

- How close are the methods? The 5 estimates are within X\% of each other.

** For functional class definition, see Table 1. 


\subsubsection{Preliminary Comments Based on the Empirical Comparison}

For each of the 21 Florida count sites, all of the 5 estimates of AADT are within $2.5 \%$ or less of each other. Actually, for 15 out of the 21 sites, the 5 estimates of AADT are within less than $1 \%$ of each other. For example with Site 170, the percent closeness (maximum ratio) of the 5 estimates is computed by

$$
\begin{aligned}
\text { Percent Closeness } & =\text { Maximum Ratio } \\
& =\frac{\text { Max Estimate-Min Estimate }}{\text { Min Estimate }} \times 100 \% \\
& =\frac{5,284-5,275}{5,275} \times 100 \% \\
& \approx 0.17 \% .
\end{aligned}
$$

For practical purposes, it can be argued that this preliminary result shows no real differences among the estimates produced by the five different methods for the count sites which all suffer from various patterns of missing data.

For most vehicle classes at each site, all of the 5 estimates of AADT are within $5 \%$ or less of each other. These AADT estimates by classes (i.e., classification data) are not as close as the estimates for all vehicle classes combined (i.e., count data). In cases where the 5 estimates of AADT are not within 5\% of each other, we observe that the estimates from Methods 1 and 3 are lower than the estimates from Methods 2, 4, and 5. A closer look at these cases reveals that there is: (i) a difference in "monthly" daily means, (ii) not a very great difference in "day of week" daily means, and (iii) a difference in amount of data from month to month, but not a very great difference in data from one day of the week to the next. Indeed, in many of these cases where the 5 estimates of AADT are not within 5\% of each other, the vehicle traffic volume is near zero or the difference among the estimates is less than " 1 " vehicle.

For vehicle classes with low mean daily traffic volurnes, a few cases gave 5 estimates which were not very close to each other. On the other hand, for vehicle classes with high mean daily traffic volumes, the 5 methods produced estimates which were very close to each other. These results may be additional motivation for combining some vehicle classes, especially among classes with low mean daily traffic volumes. 
Similar to results with count data and classification data, the 5 different estimation methods appear to have little effect on the daily means of ESAL and weight for each vehicle class [4].

\section{SUMMARY REMARKS \\ Five Different Estimation Methods}

Almost all of the 5 estimates of annual estimates (AADT, AADT by vehicle class, daily ESAL and weight per vehicle) are within at most $5 \%$ of each other. Because no practical differences were observed among the estimates produced by the five different approaches (including the AASHTO Method), we recommend Method One for simplicity! Method One calls for computing the average of the daily traffic estimates.

\subsection{Missing Data}

Continuous traffic monitoring is plagued by missing (i) count data, (ii) classification count data, and (iii) weigh-in-motion data. Data are missing for several reasons including (i) equipment failure, (ii) construction, (iii) removal of data during the editing process, and (iv) the time of equipment installation. Tables 21, 22, and 23 show graphics which show the level of missing 1994 days of data at the sites for the different types of data.

For the sites considered, relatively few days of weigh-in-motion data are missing. A close examination of the three tables (graphics) would reveal that missing data for a given site are roughly uniformly distributed over the days of the week, but not roughly uniformly distributed over the months of the year. For example, by looking at the 8 classification sites, we show the number of days in 1994 where data are missing by days of week (Table 24) and by month of year (Table 25). 
Table 21.

Graphic of Missing Days for the 21 Selected Sites from Florida's District 5

(Block Means Missing Day)

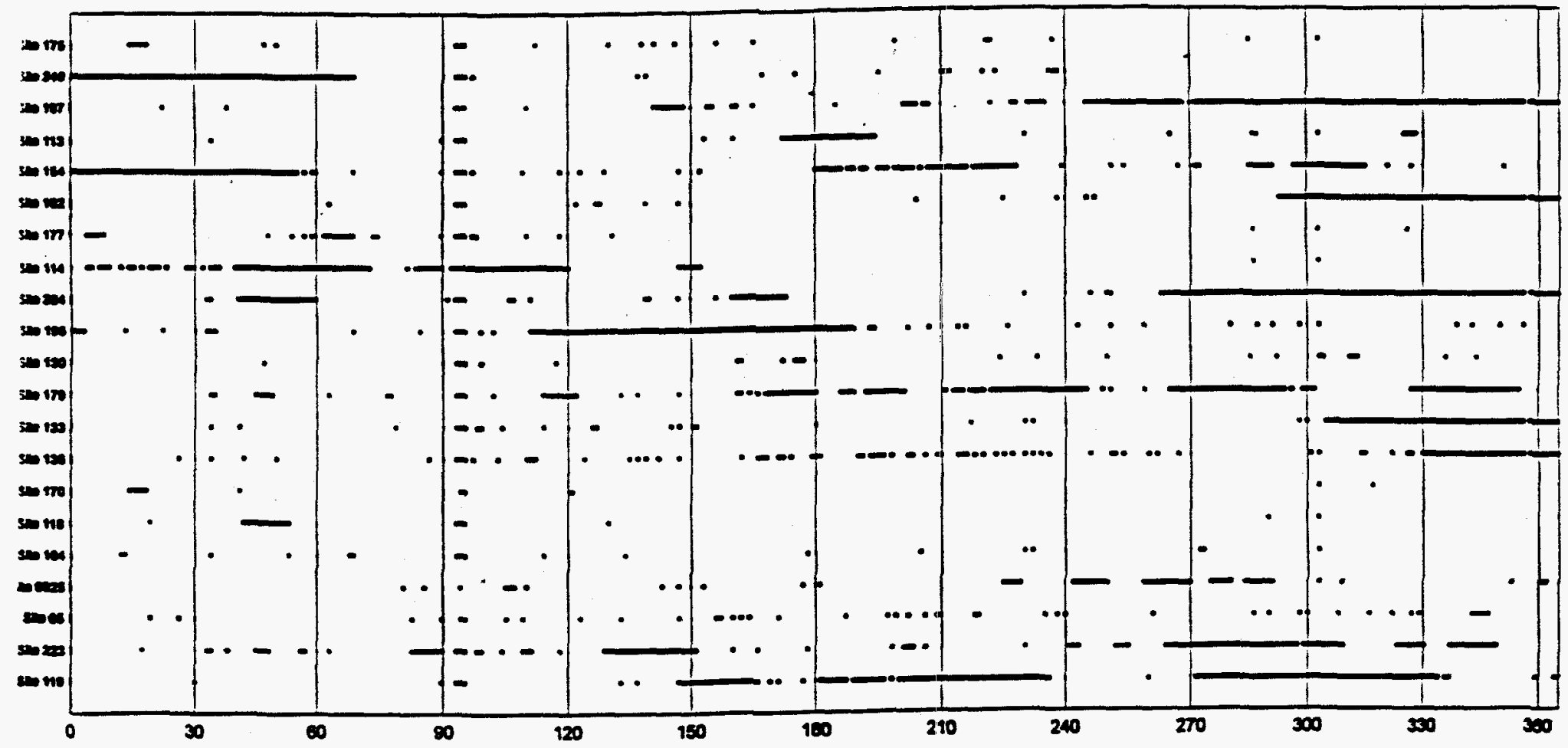

Done in the Your 
Table 22.

Graphic of Missing Days for the 8 Selected Classification Sites from Florida's District 5 (Block Means Missing Day)

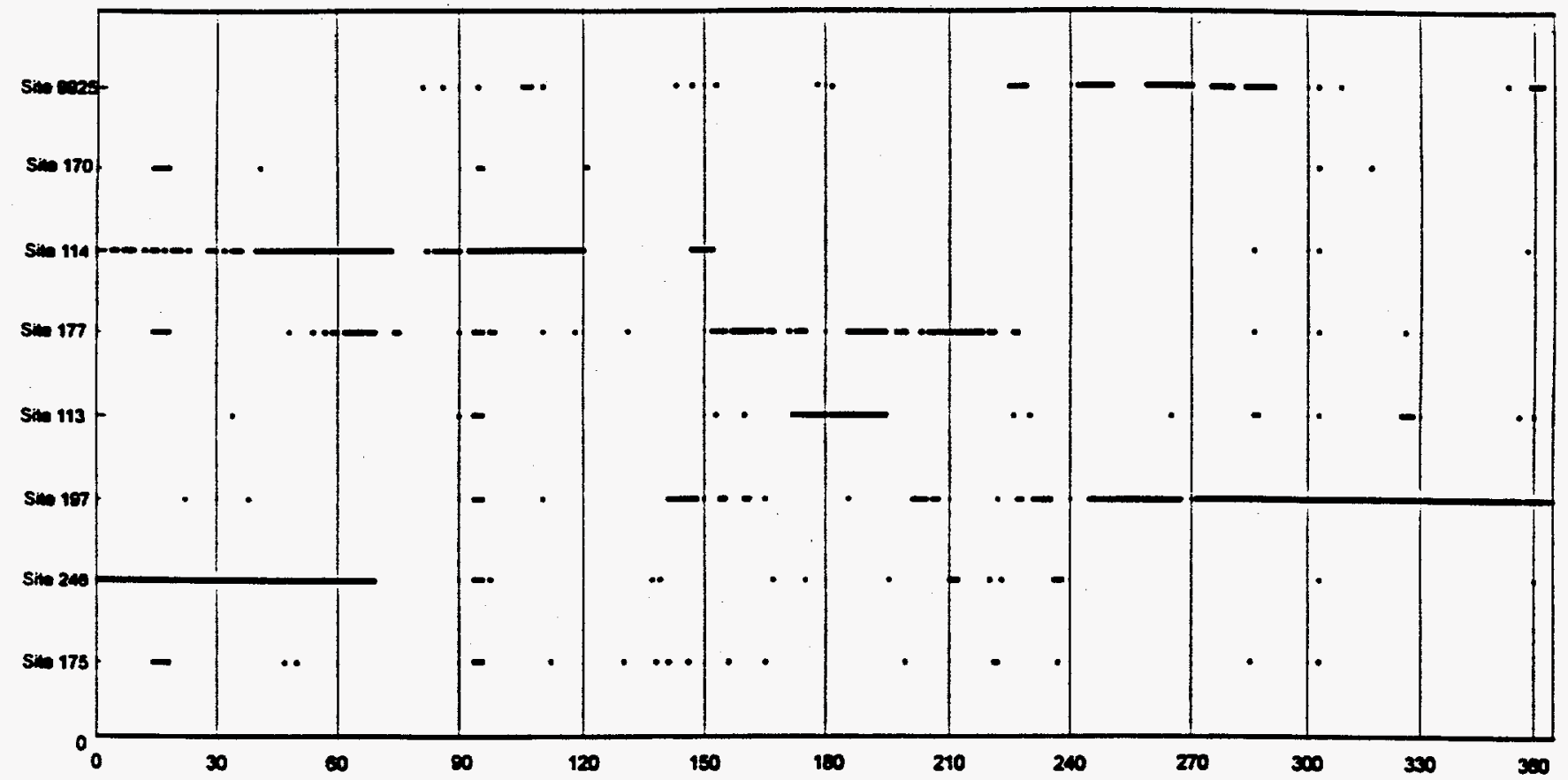

Table 23.

Graphic of Missing Days for the 6 Selected WIM Sites from Washington

(Block Means Missing Day)

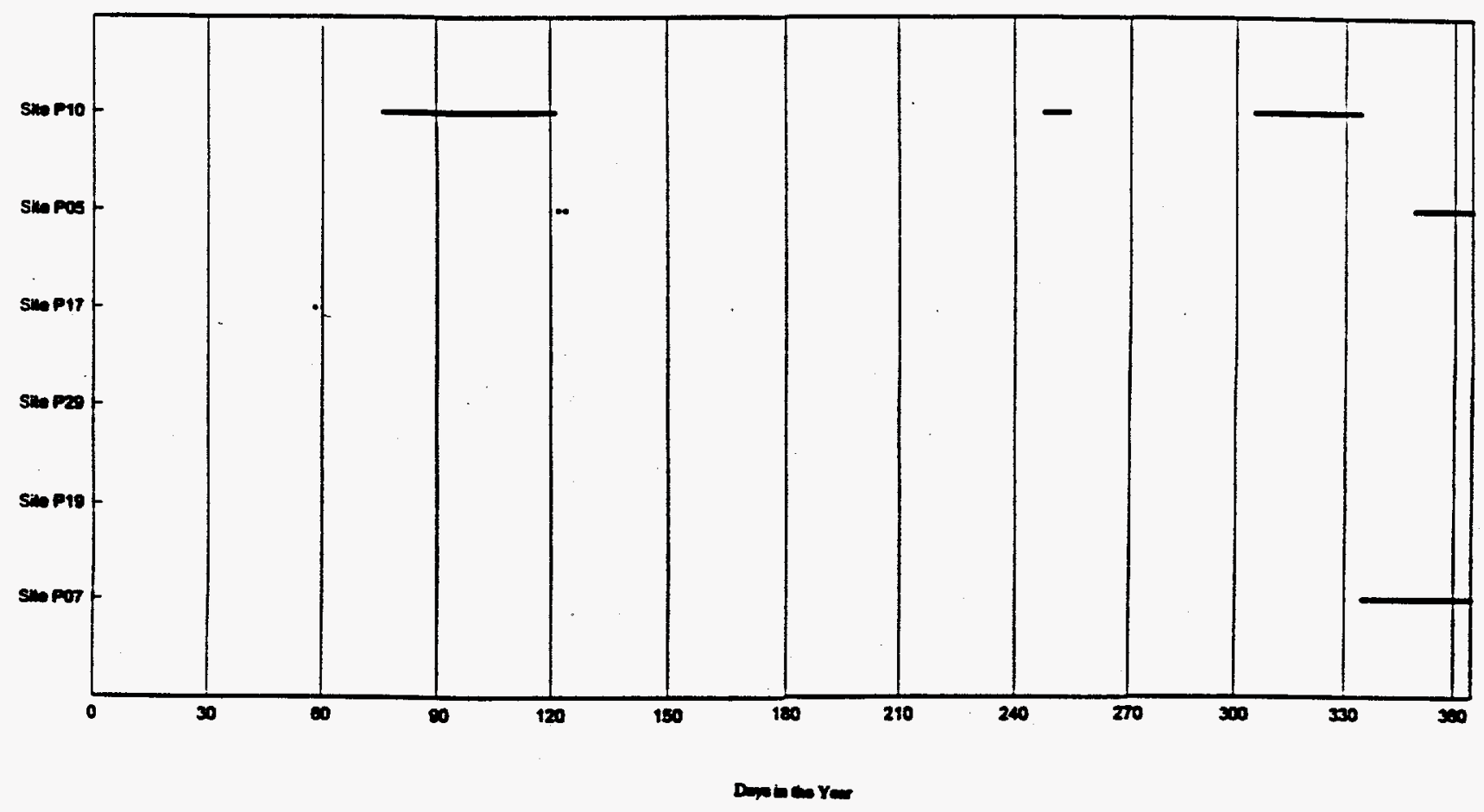


Table 24.

1994 Missing Days of Classification Data by Days of Week

\begin{tabular}{|r|rrrrrrr|}
\hline Site & Sun & Mon & Tue & Wed & Thu & Fri & Sat \\
\hline 9925 & 10 & 10 & 10 & 8 & 6 & 7 & 7 \\
170 & 4 & 3 & 2 & 0 & 1 & 1 & 1 \\
114 & 14 & 12 & 12 & 15 & 13 & 16 & 17 \\
177 & 10 & 14 & 11 & 13 & 14 & 10 & 9 \\
113 & 6 & 6 & 6 & 5 & 12 & 4 & 3 \\
197 & 20 & 23 & 22 & 21 & 20 & 23 & 24 \\
246 & 13 & 13 & 12 & 11 & 16 & 12 & 11 \\
175 & 4 & 3 & 5 & 4 & 2 & 2 & 3 \\
\hline
\end{tabular}

Table 25.

1994 Missing Days of Classification Data by Months of Year

\begin{tabular}{|r|rrrrrrrrrrrrr|}
\hline Site & Jan & Feb & Mar & Apr & May & Jun & Jul & Aug & Sep & Oct & Nov & Dec \\
\hline 9925 & 0 & 0 & 2 & 5 & 2 & 3 & 0 & 7 & 19 & 15 & 1 & 4 \\
170 & 5 & 1 & 0 & 2 & 1 & 0 & 0 & 1 & 0 & 1 & 1 & 0 \\
114 & 15 & 24 & 22 & 29 & 5 & 1 & 0 & 0 & 0 & 2 & 0 & 1 \\
177 & 5 & 4 & 11 & 7 & 1 & 18 & 22 & 10 & 0 & 2 & 1 & 0 \\
113 & 0 & 1 & 1 & 3 & 0 & 12 & 13 & 2 & 1 & 3 & 4 & 2 \\
197 & 1 & 1 & 0 & 4 & 8 & 5 & 7 & 8 & 27 & 31 & 30 & 31 \\
246 & 31 & 28 & 10 & 4 & 2 & 2 & 4 & 5 & 0 & 1 & 0 & 1 \\
175 & 5 & 2 & 0 & 4 & 4 & 2 & 1 & 3 & 0 & 2 & 0 & 0 \\
\hline
\end{tabular}


It is clear from Tables 21,22 , and 23 that the missing days of traffic monitoring data occur in single isolated days as well as in consecutive days.

\subsection{Simulations with Randomly Missing Data}

The effect of missing data on annual traffic estimates (i.e., AADT, AADT by vehicle class, average daily ESAL, and weight per vehicle) was investigated. On all study sites, we randomly set data to be missing. Three levels of missing data were simulated:

(i) $5 \%$ of days of data missing at random,

(ii) $20 \%$ of days of data missing at random, and

(iii) $50 \%$ of days of data missing at random.

The simulation follows the following steps. For a specific Florida site, let $\mathrm{N}$ be its number of days of available "edited" count data. Let $d_{1}=.05 \mathrm{~N}$, and round to the nearest integer. Next, randomly select and remove $d_{1}$ days of count data from the given site. For the $N-d_{1}$ remaining days of count data, compute the average daily traffic and the associated coefficient of variation. Replace the $d_{1}$ days and repeat the above steps 999 additional times. Thus, for the given site, we have 1,000 different values of average daily traffic and 1,000 different coefficients of variation. Compute the average of the 1,000 values of average daily traffic and denote it by SADT $_{1}$ for "simulated average daily traffic" without $5 \%$ of days of count data. This process was repeated for each of the 21 Florida count sites.

We repeated this procedure under the scenarios that $20 \%$ or $50 \%$ of days of count data were missing. The simulated average daily traffic without $20 \%$ of days of count data is denoted by $\mathrm{SADT}_{2}$, and the simulated average daily traffic without $50 \%$ of days of count data is denoted by $\mathrm{SADT}_{3}$. The results of this simulation of count data are described in Table 26.

If data for $5 \%$ or $20 \%$ of the days are missing at random, the simulated AADTs (denoted by $\mathrm{SADT}_{1}$ and $\mathrm{SADT}_{2}$, respectively) are essentially the same as the original AADT for each site. Though the simulated average value of AADT when data for $50 \%$ of the days are missing (denoted by $\mathrm{SADT}_{3}$ ) is also close to the original AADT, it does not tend to be as close as $\mathrm{SADT}_{1}$ and $\mathrm{SADT}_{2}$. Note also from the values in parentheses in columns 5, 6 and 7 of Table 26 that the simulated standard errors increase from $\mathrm{SADT}_{1}$ to $\mathrm{SADT}_{2}$ to $\mathrm{SADT}_{3}$. 
Under random sampling, sampling theory states that the expected values of $\mathrm{SADT}_{1}, \mathrm{SADT}_{2}$ and $\mathrm{SADT}_{3}$ will all be AADT and that the standard errors will increase from $\mathrm{SADT}_{1}$ to $\mathrm{SADT}_{2}$ to $\mathrm{SADT}_{3}$. That is, the more (randomly) missing data, the more unreliable the estimate, even though the estimate is on target (on average).

For these 21 sites, one might argue that even with $50 \%$ of the count data missing at random, the reliability of the estimate is quite high. And, the loss in AADT reliability due to missing data might very well be tolerable. Results based on sites examined suggest that randomly missing data do not significantly bias the estimation of average traffic and loading patterns. More research is needed, which is beyond the scope of this research study.

In summary, these preliminary simulations suggest that randomly missing days of count data have little effect on the average value of the coefficient of variation with $A A D T$, based on the nonmissing days of count data. Similarly, randomly missing days of classification count data (or weigh-in-motion data) appear to have little effect on the mean traffic volume estimate (or weigh-inmotion estimates) and associated CV estimate for each vehicle class. 
Table 26.

Simulation Results for AADT, with Randomly Missing Days of Count Data*

\begin{tabular}{|c|c|c|c|c|c|c|c|c|c|}
\hline \multirow{2}{*}{$\begin{array}{l}\text { Func } \\
\text { Class" }\end{array}$} & \multirow[b]{2}{*}{ Site } & \multirow[b]{2}{*}{$\mathrm{N}$} & \multirow[t]{2}{*}{$\begin{array}{l}\text { Original } \\
\text { AADT }\end{array}$} & \multicolumn{3}{|c|}{$\begin{array}{c}\text { Amount of Randomly } \\
\text { Missing Data }\end{array}$} & \multicolumn{3}{|c|}{$\begin{array}{l}\text { How Close are SADT } \\
\text { and AADT? The } 2 \text { estimates } \\
\text { are within } \mathrm{X} \% \text { of each other. }\end{array}$} \\
\hline & & & & SADT $_{1}{ }^{\cdots * *}$ & $\mathrm{SADT}_{2}{ }^{* * *}$ & $\mathrm{SADT}_{3}{ }^{\cdots * *}$ & SADT $_{1}$ & $\mathrm{SADT}_{2}$ & $\mathrm{SADT}_{3}$ \\
\hline 01 & 119 & 212 & 30,180 & $\begin{array}{c}30,185 \\
(101)\end{array}$ & $\begin{array}{c}30,179 \\
(215)\end{array}$ & $\begin{array}{c}30,207 \\
(445)\end{array}$ & $0.02 \%$ & $0.00 \%$ & $0.09 \%$ \\
\hline 02 & 223 & 231 & 4,474 & $\begin{array}{c}4,474 \\
(12)\end{array}$ & $\begin{array}{c}4,475 \\
(24)\end{array}$ & $\begin{array}{c}4,475 \\
(46)\end{array}$ & $0.01 \%$ & $0.02 \%$ & $0.02 \%$ \\
\hline 02 & 65 & 322 & 7,382 & $\begin{array}{c}7,381 \\
(11)\end{array}$ & $\begin{array}{c}7,383 \\
(22)\end{array}$ & $\begin{array}{c}7,385 \\
(45)\end{array}$ & $0.01 \%$ & $0.01 \%$ & $0.04 \%$ \\
\hline 02 & 9925 & 308 & 12,661 & $\begin{array}{c}12,661 \\
(25)\end{array}$ & $\begin{array}{c}12,661 \\
(55)\end{array}$ & $\begin{array}{l}12,657 \\
(109)\end{array}$ & $0.00 \%$ & $0.00 \%$ & $0.03 \%$ \\
\hline 02 & 104 & 347 & 22,098 & $\begin{array}{c}22,099 \\
(21)\end{array}$ & $\begin{array}{c}22,101 \\
(48)\end{array}$ & $\begin{array}{l}22,091 \\
(95)\end{array}$ & $0.00 \%$ & $0.02 \%$ & $0.03 \%$ \\
\hline 02 & 118 & 345 & 22,262 & $\begin{array}{c}22,264 \\
(34)\end{array}$ & $\begin{array}{c}22,263 \\
(75)\end{array}$ & $\begin{array}{c}22,256 \\
(156)\end{array}$ & $0.01 \%$ & $0.00 \%$ & $0.03 \%$ \\
\hline 06 & 170 & 353 & 5,284 & $\begin{array}{c}5,283 \\
(8)\end{array}$ & $\begin{array}{c}5,285 \\
(17)\end{array}$ & $\begin{array}{c}5,285 \\
(36)\end{array}$ & $0.01 \%$ & $0.03 \%$ & $0.01 \%$ \\
\hline 07 & 136 & 263 & 6,336 & $\begin{array}{l}6,336 \\
(17)\end{array}$ & $\begin{array}{c}6,336 \\
(37)\end{array}$ & $\begin{array}{c}6,336 \\
(71)\end{array}$ & $0.01 \%$ & $0.00 \%$ & $0.00 \%$ \\
\hline 11 & 133 & 283 & 28,026 & $\begin{array}{c}28,028 \\
(58)\end{array}$ & $\begin{array}{c}28,031 \\
(128)\end{array}$ & $\begin{array}{c}28,016 \\
(261)\end{array}$ & $0.01 \%$ & $0.02 \%$ & $0.04 \%$ \\
\hline 11 & 179 & 210 & 54,599 & $\begin{array}{l}54,599 \\
(121)\end{array}$ & $\begin{array}{l}54,592 \\
(264)\end{array}$ & $\begin{array}{c}54,603 \\
(523)\end{array}$ & $0.00 \%$ & $0.01 \%$ & $0.01 \%$ \\
\hline 11 & 130 & 341 & 110,865 & $\begin{array}{c}110,863 \\
(124) \\
\end{array}$ & $\begin{array}{c}110,861 \\
(254) \\
\end{array}$ & $\begin{array}{c}110,847 \\
(529) \\
\end{array}$ & $0.00 \%$ & $0.00 \%$ & $0.02 \%$ \\
\hline
\end{tabular}

* Simulated results are rounded. Some percents rounded to zero.

** For functional class definition, see Table 1.

*** The numbers in parenthesis are the standard deviations of the 1,000 simulated values $\mathrm{SADT}_{i}$ for each site. 
Table 26. (continued)

Simulation Results for AADT, with Randomly Missing Days of Count Data*

\begin{tabular}{|c|c|c|c|c|c|c|c|c|c|}
\hline \multirow{2}{*}{$\begin{array}{l}\text { Func } \\
\text { Class** } \\
\end{array}$} & \multirow[b]{2}{*}{ Site } & \multirow[b]{2}{*}{$\mathbf{N}$} & \multirow[t]{2}{*}{$\begin{array}{l}\text { Original } \\
\text { AADT }\end{array}$} & \multicolumn{3}{|c|}{$\begin{array}{l}\text { Amount of Randomly } \\
\text { Missing Data } \\
20 \% \\
\end{array}$} & \multicolumn{3}{|c|}{$\begin{array}{l}\text { How Close are SADT, } \\
\text { and AADT? The } 2 \text { estimates } \\
\text { are within X\% of each other. }\end{array}$} \\
\hline & & & & SADT $_{1}{ }^{\cdots *}$ & SADT $_{2}{ }^{\cdots \cdots}$ & $\mathrm{SADT}_{3}{ }^{* \cdots *}$ & $\mathrm{SADT}_{1}$ & $\mathrm{SADT}_{2}$ & $\mathrm{SADT}_{3}$ \\
\hline 11 & 196 & 252 & 154,304 & $\begin{array}{r}154,308 \\
(265)\end{array}$ & $\begin{array}{r}154,318 \\
(590)\end{array}$ & $\begin{array}{r}154,339 \\
(1,175)\end{array}$ & $0.00 \%$ & $0.01 \%$ & $0.02 \%$ \\
\hline 12 & 204 & 212 & 28,294 & $\begin{array}{r}28,293 \\
(54)\end{array}$ & $\begin{array}{r}28,287 \\
(113)\end{array}$ & $\begin{array}{r}28,301 \\
(228)\end{array}$ & $0.01 \%$ & $0.03 \%$ & $0.02 \%$ \\
\hline 14 & 114 & 267 & 14,436 & $\begin{array}{r}14,436 \\
(28)\end{array}$ & $\begin{array}{r}14,436 \\
(58)\end{array}$ & $\begin{array}{r}14,429 \\
(126)\end{array}$ & $0.00 \%$ & $0.01 \%$ & $0.05 \%$ \\
\hline 14 & 177 & 333 & 33,290 & $\begin{array}{r}33,292 \\
(69)\end{array}$ & $\begin{array}{r}33,282 \\
(155)\end{array}$ & $\begin{array}{r}33,303 \\
(314)\end{array}$ & $0.01 \%$ & $0.02 \%$ & $0.04 \%$ \\
\hline 14 & 102 & 278 & 40,753 & $\begin{array}{r}40,756 \\
(83)\end{array}$ & $\begin{array}{r}40,753 \\
(170)\end{array}$ & $\begin{array}{r}40,755 \\
(343)\end{array}$ & $0.01 \%$ & $0.00 \%$ & $0.00 \%$ \\
\hline 14 & 154 & 220 & 44,030 & $\begin{array}{r}44,031 \\
(77)\end{array}$ & $\begin{array}{r}44,030 \\
(176)\end{array}$ & $\begin{array}{r}44,035 \\
(338)\end{array}$ & $0.00 \%$ & $0.00 \%$ & $0.01 \%$ \\
\hline 14 & 113 & 326 & 45,825 & $\begin{array}{r}45,826 \\
(82)\end{array}$ & $\begin{array}{r}45,829 \\
(173)\end{array}$ & $\begin{array}{r}45,820 \\
(369)\end{array}$ & $0.00 \%$ & $0.01 \%$ & $0.01 \%$ \\
\hline 14 & 197 & 212 & 47,270 & $\begin{array}{r}47,272 \\
(120)\end{array}$ & $\begin{array}{r}47,278 \\
(263)\end{array}$ & $\begin{array}{r}47,270 \\
(527)\end{array}$ & $0.01 \%$ & $0.02 \%$ & $0.00 \%$ \\
\hline 16 & 246 & 278 & 7,681 & $\begin{array}{r}7,681 \\
(11)\end{array}$ & $\begin{array}{r}7,682 \\
(23)\end{array}$ & $\begin{array}{r}7,682 \\
(49)\end{array}$ & $0.00 \%$ & $0.01 \%$ & $0.01 \%$ \\
\hline 16 & 175 & 342 & 39,920 & $\begin{array}{r}39,917 \\
(113)\end{array}$ & $\begin{array}{r}39,917 \\
(238)\end{array}$ & $\begin{array}{r}39,927 \\
(485)\end{array}$ & $0.01 \%$ & $0.01 \%$ & $0.02 \%$ \\
\hline
\end{tabular}

* Simulated results are rounded. Some percents rounded to zero.

** For functional class definition, see Table 1.

*** The numbers in parenthesis are the standard deviations of the 1,000 simulated values $\mathrm{SADT}_{\mathrm{i}}$ for each site. 
The simulated average values of coefficient of variation $\left(\mathrm{SCV}_{1}, \mathrm{SCV}_{2}\right.$ and $\mathrm{SCV}_{3}$ in Table 27) are all essentially the same as CV. As with AADT, if we look at the associated simulated standard errors in parenthesis, we see that $\mathrm{SCV}_{1}$ is more reliable than $\mathrm{SCV}_{2}$ which is more reliable than $\mathrm{SCV}_{3}$.

In addition to having single days of data missing in isolation, missing data also tend to be missing for 2 or more consecutive days. This seems reasonable if the main reason for missing data is equipment failure and if the time to discover and repair the failure is allowed. The effect of the following different variations of missing consecutive days on AADT and CV was investigated.

(i) One randomly missing week.

(ii) Two randomly missing weeks.

(iii) One randomly missing period of two consecutive weeks.

(iv) Two randomly missing periods of two consecutive weeks.

(v) One randomly missing month.

(vi) Two randomly missing months.

(vii) One randomly missing period of two consecutive months.

These missing data patterns emulate, to some extent, data patterns that were observed in Tables 21 through 23.

All seven different patterns of randomly consecutive missing days of count data have simulated average values $\mathrm{SADT}_{\mathrm{i}}(\mathrm{i}=\mathrm{I}, \ldots, \mathrm{VII})$ that are all essentially the same as $\mathrm{AADT}$ for each site and are all quite close to each other for each site. The simulated standard errors increase from $\mathrm{SADT}_{\mathrm{I}}$ to $\mathrm{SADT}_{\mathrm{VII}}$.

There appear to be no patterns of systematically missing data at each of the selected sites (See Tables 21 through 23). It is difficult to say that the missing days of data are missing at random. However, the message of this analysis is that if we have randomly missing days, even high levels of randomly missing days, reliable results for AADT (or AADT by vehicle class, average daily ESAL and weight per vehicle) can be obtained. This is based on theoretical results in probability sampling theory. Even if we have randomly consecutive missing days (clusters), reliable results for AADT can still be obtained which are also based on theoretical results. These findings also suggest the possibility of estimating typical traffic and loading patterns based on a statistical sample of the continuous data, rather than based on the entirety of the available continuous data. One advantage of sampling continuous data is to reduce the data processing 
burden. Sampling strategies (based on "days" or "clusters of days") can be developed that reliably provide the details of the sought after "100\% data from continuously monitored sites."

\section{SUMMARY REMARKS \\ Effects of Missing Data on Annual Traffic Estimates}

Continuous traffic monitoring is plagued by missing data which seems to mainly be due to equipment failure, construction schedules, and installation dates. Data do not appear to be missing for certain hours of the day, days of the week, nor months of the year. Data are missing on isolated days as well as on consecutive days. For 6 weigh-in-motion sites, entire months of weigh-in-motion data at a site can be missing due to construction or new installation. We observed no systematic pattern of missing data. Continuous traffic monitoring which results in 365 days of complete data currently seems to be uncommon.

Missing data seem to have a negligible effect on estimated traffic characteristics (i.e., AADT, AADT by vehicle class, daily ESAL or daily weight per vehicle). However, the reliability of the estimated traffic characteristics (i.e., AADT, AADT by vehicle class, daily ESAL or weight per vehicle) decreases (on average) as the amount of randomly missing data increase $(5 \% \rightarrow 20 \% \rightarrow 50 \%)$. That is, as the amount of randomly missing data increases, the more unreliable the estimates, even though they are on target (on average). In many cases, the loss of reliability is tolerable. Similarly, the amount of missing data had negligible effect on the estimated cqefficients of variation for the sites considered.

It is important to track missing data at each monitoring site. Graphics such as shown in Tables 21,22 , or 23 can easily reveal systematic patterns of missing data. Systematic patterns of missing data typically signal potential equipment problems. By tracking missing data on a periodic basis, these problems can be corrected in a timely fashion. 
Table 27.

Simulation Results for CV with Randomly Missing Days of Count Data*

\begin{tabular}{|c|c|c|c|c|c|c|c|c|c|c|}
\hline \multirow{2}{*}{$\begin{array}{l}\text { Func } \\
\text { Class }\end{array}$} & \multirow{2}{*}{$\begin{array}{l}\text { Vol } \\
\text { Group }\end{array}$} & \multirow[b]{2}{*}{ Site } & \multirow[b]{2}{*}{$\mathrm{N}$} & \multirow[b]{2}{*}{$\mathrm{CV}$} & \multicolumn{3}{|c|}{$\begin{array}{l}\text { Amount of Randomly } \\
\text { Missing Data }\end{array}$} & \multicolumn{3}{|c|}{$\begin{array}{c}\text { How Close are } \mathrm{SCV}_{\mathrm{i}} \\
\text { and CV? The } 2 \text { estimates } \\
\text { are within } \mathrm{X} \% \text { of each other.** }\end{array}$} \\
\hline & & & & & SCV, :- & $\mathrm{SCV}_{2}{ }^{* * *}$ & $\mathrm{SCV}_{3} \cdots$ & $\mathrm{SCV}_{1}$ & $\mathrm{SCV}_{2}$ & $\mathrm{SCV}_{3}$ \\
\hline 01 & 04 & 119 & 212 & 21.2 & $\begin{array}{l}21.2 \\
(0.3)\end{array}$ & $\begin{array}{l}21.2 \\
(0.6)\end{array}$ & $\begin{array}{r}21.2 \\
(1.3)\end{array}$ & $0.05 \%$ & $0.05 \%$ & $0.33 \%$ \\
\hline 02 & 01 & 223 & 231 & 16.5 & $\begin{array}{r}16.5 \\
(0.4)\end{array}$ & $\begin{array}{r}16.5 \\
(0.8)\end{array}$ & $\begin{array}{r}16.4 \\
(1.6)\end{array}$ & $0.18 \%$ & $0.06 \%$ & $0.79 \%$ \\
\hline 02 & 02 & 65 & 322 & 11.0 & $\begin{array}{r}11.1 \\
(0.1)\end{array}$ & $\begin{array}{l}11.1 \\
(0.2)\end{array}$ & $\begin{array}{r}11.0 \\
(0.4)\end{array}$ & $0.04 \%$ & $0.04 \%$ & $0.15 \%$ \\
\hline 02 & 03 & 9925 & 308 & 15.0 & $\begin{array}{r}15.0 \\
(0.2)\end{array}$ & $\begin{array}{l}15.0 \\
(0.4)\end{array}$ & $\begin{array}{r}15.0 \\
(0.7)\end{array}$ & $0.06 \%$ & $0.06 \%$ & $0.26 \%$ \\
\hline 02 & 05 & 104 & 347 & 8.0 & $\begin{array}{r}8.0 \\
(0.1)\end{array}$ & $\begin{array}{r}8.0 \\
(0.2)\end{array}$ & $\begin{array}{r}8.0 \\
(0.4)\end{array}$ & $0.08 \%$ & $0.08 \%$ & $0.08 \%$ \\
\hline 02 & 05 & 118 & 345 & 12.6 & $\begin{array}{r}12.6 \\
(0.2)\end{array}$ & $\begin{array}{r}12.6 \\
(0.4)\end{array}$ & $\begin{array}{r}12.6 \\
(0.7)\end{array}$ & $0.06 \%$ & $0.06 \%$ & $0.29 \%$ \\
\hline 06 & 03 & 170 & 353 & 12.3 & $\begin{array}{r}12.3 \\
(0.1)\end{array}$ & $\begin{array}{r}12.3 \\
(0.3)\end{array}$ & $\begin{array}{r}12.3 \\
(0.5)\end{array}$ & $0.07 \%$ & $0.18 \%$ & $0.10 \%$ \\
\hline 07 & 03 & 136 & 263 & 18.6 & $\begin{array}{r}18.6 \\
(0.2)\end{array}$ & $\begin{array}{r}18.6 \\
(0.4)\end{array}$ & $\begin{array}{r}18.6 \\
(0.8)\end{array}$ & $0.03 \%$ & $0.07 \%$ & $0.07 \%$ \\
\hline 11 & 02 & 133 & 283 & 15.4 & $\begin{array}{r}15.4 \\
(0.2)\end{array}$ & $\begin{array}{r}15.4 \\
(0.5)\end{array}$ & $\begin{array}{l}15.3 \\
(1.0)\end{array}$ & $0.06 \%$ & $0.00 \%$ & $0.46 \%$ \\
\hline 11 & 03 & 179 & 210 & 13.7 & $\begin{array}{r}13.7 \\
(0.2)\end{array}$ & $\begin{array}{r}13.8 \\
(0.4)\end{array}$ & $\begin{array}{r}13.7 \\
(0.7)\end{array}$ & $0.01 \%$ & $0.14 \%$ & $0.30 \%$ \\
\hline 11 & 05 & 130 & 341 & 8.9 & $\begin{array}{r}8.9 \\
(0.1)\end{array}$ & $\begin{array}{r}8.9 \\
(0.2)\end{array}$ & $\begin{array}{r}8.9 \\
(0.3)\end{array}$ & $0.04 \%$ & $0.07 \%$ & $0.15 \%$ \\
\hline 11 & 07 & 196 & 252 & 12.2 & $\begin{array}{r}12.2 \\
(0.1)\end{array}$ & $\begin{array}{r}12.2 \\
(0.3)\end{array}$ & $\begin{array}{r}12.2 \\
(0.6)\end{array}$ & $0.01 \%$ & $0.01 \%$ & $0.01 \%$ \\
\hline 12 & 02 & 204 & 212 & 11.7 & $\begin{array}{r}11.7 \\
(0.2)\end{array}$ & $\begin{array}{r}11.8 \\
(0.3)\end{array}$ & $\begin{array}{l}11.7 \\
(0.7)\end{array}$ & $0.03 \%$ & $0.06 \%$ & $0.11 \%$ \\
\hline 14 & 04 & 114 & 267 & 13.6 & $\begin{array}{r}13.6 \\
(0.2)\end{array}$ & $\begin{array}{r}13.6 \\
(0.3)\end{array}$ & $\begin{array}{r}13.7 \\
(0.7)\end{array}$ & $0.01 \%$ & $0.01 \%$ & $0.30 \%$ \\
\hline 14 & 07 & 177 & 333 & 16.6 & $\begin{array}{r}16.6 \\
(0.2)\end{array}$ & $\begin{array}{r}16.6 \\
(0.4)\end{array}$ & $\begin{array}{r}16.6 \\
(0.7)\end{array}$ & $0.06 \%$ & $0.06 \%$ & $0.18 \%$ \\
\hline 14 & 08 & 102 & 278 & 14.4 & $\begin{array}{r}14.4 \\
(0.2)\end{array}$ & $\begin{array}{r}14.4 \\
(0.4)\end{array}$ & $\begin{array}{r}14.4 \\
(0.8)\end{array}$ & $0.02 \%$ & $0.05 \%$ & $0.30 \%$ \\
\hline 14 & 08 & 154 & 220 & 11.6 & $\begin{array}{r}11.6 \\
(0.1)\end{array}$ & $\begin{array}{r}11.6 \\
(0.3)\end{array}$ & $\begin{array}{l}11.6 \\
(0.6)\end{array}$ & $0.03 \%$ & $0.03 \%$ & $0.03 \%$ \\
\hline 14 & 09 & 113 & 326 & 14.0 & $\begin{array}{r}14.0 \\
(0.2)\end{array}$ & $\begin{array}{r}14.0 \\
(0.4)\end{array}$ & $\begin{array}{r}14.0 \\
(0.7)\end{array}$ & $0.04 \%$ & $0.04 \%$ & $0.11 \%$ \\
\hline 14 & 09 & 197 & 212 & 16.1 & $\begin{array}{r}16.1 \\
(0.2)\end{array}$ & $\begin{array}{l}16.1 \\
(0.5)\end{array}$ & $\begin{array}{l}16.1 \\
(1.0)\end{array}$ & $0.01 \%$ & $0.08 \%$ & $0.01 \%$ \\
\hline 16 & 03 & 246 & 278 & 10.4 & $\begin{array}{r}10.4 \\
(0.1)\end{array}$ & $\begin{array}{r}10.4 \\
(0.2)\end{array}$ & $\begin{array}{l}10.4 \\
(0.5)\end{array}$ & $0.06 \%$ & $0.04 \%$ & $0.04 \%$ \\
\hline 16 & 08 & 175 & 342 & 22.4 & $\begin{array}{r}22.4 \\
(0.2) \\
\end{array}$ & $\begin{array}{r}22.4 \\
(0.5) \\
\end{array}$ & $\begin{array}{r}22.4 \\
(1.0) \\
\end{array}$ & $0.01 \%$ & $0.01 \%$ & $0.08 \%$ \\
\hline
\end{tabular}

* The numbers in parenthesis are the standard deviations of the 1,000 simulated values $\mathrm{SCV}_{i}$ for each site.

** See Appendix $C$ for more details.

*** Simulated results are rounded. Some percents rounded to zero. 


\subsection{Effect of Holidays and Special Days}

The table below lists holidays and "holiday periods" in 1994, defined with the assistance of the Florida DOT. For each of the 21 selected sites, Table 28 presents the AADT and CV calculated under the following conditions:

Condition 1: All days of data used

Condition 2: Data with all specific holidays removed

Condition 3: Data with all "holiday period" days removed

where

\begin{tabular}{lll} 
Holiday & Specific Date & “Holiday Period" \\
\hline New Year's Day & January 1, 1994 & January 1, 2, 3, 4, 1994 \\
Martin Luther King B-Day & January 17, 1994 & $\begin{array}{l}\text { January 14, 15, 16, 17, 18, } \\
1994\end{array}$ \\
Memorial Day & May 30, 1994 & May 27, 28, 29, 30, 31, 1994 \\
Independence Day & July 4, 1994 & July 1, 2, 3, 4, 5, 6, 7, 1994 \\
Labor Day & September 5, 1994 & September 2, 3, 4, 5, 6, 1994 \\
Veterans Day & November 11, 1994 & November 10, 11, 12, 1994 \\
Thanksgiving & November 24, 1994 & November 21, 22, 23, 24, \\
& & $25,26,27,28,1994$ \\
Christmas & December 25, 1994 & December 18, 19, 20, 21, 22, \\
& & $23,24,25,26,27,28,29$, \\
& & $30,31,1994$ \\
\hline
\end{tabular}

From Table 28, the AADT increases at 18 of the 21 sites from Condition 1 (all available days) to Condition 2 (all days except specific holidays). Also, the AADT increases at 15 of the 21 sites from Condition 1 (all available days) to Condition 3 (all days except those in holiday periods). However, in both cases, the increases (and decreases) are relatively small amounts. The closeness of the AADT values under the three different conditions is reflected in Table 28. 
Based on these preliminary results, and assuming a minimum number of days of available edited data, the effect of holidays and holiday periods on overall AADT is negligible. Similarly, the effect of holiday and holiday period traffic seems negligible on overall daily traffic counts, ESAL, and weight estimates for each vehicle class.

From Table 28, the (rounded) CV decreases at 16 of the 21 sites from Condition 1 (all available days) to Condition 2 (all days except specific holidays). Also the (rounded) CV decreases at 20 of the 21 sites from Condition 1 (all available days) to Condition 3 (all days except those in holiday periods). However, in both cases these decreases are small. Moreover, these decreases in $\mathrm{CV}$ are not surprising when one considers that the daily traffic on these holiday period days is less than on the rest of the days.

Although the effect of holidays and holiday periods on overall AADT appears negligible, the effect on CV, i.e., variability, is small but not negligible. Similar results were observed for the classification data [3] and for the weigh-in-motion data [4].

\section{SUMMARY REMARKS \\ Effect of Holiday and Special Days on Annual Traffic Characteristics}

Although the effect of holidays and holiday periods appears negligible on overall AADT, daily traffic counts by vehicle class, daily ESAL and weight estimates for each vehicle class, the effect on CV (i.e., variability) is small but not negligible.

It is very interesting to note that removal of holidays and holiday periods tended to yield increased AADT at most of the sites examined. This suggests that the traffic is lower during the holidays than during non-holidays and seems to refute the common belief that holiday periods have more traffic. Examination of this point is recommended for more sites in more states. The observation that CV's decrease when holidays and holiday periods are removed indicates that there is likely more traffic variability during holiday periods. 
Table 28.

Effect of Holidays and Special Days on AADT and CV (\%)

\begin{tabular}{|c|c|c|c|c|c|c|c|c|c|}
\hline \multirow{3}{*}{$\begin{array}{l}\text { Func'l } \\
\text { Class** }\end{array}$} & \multirow{3}{*}{ Site } & \multicolumn{3}{|c|}{ AADT } & \multirow{3}{*}{$\begin{array}{l}\text { How Close } \\
\text { Are The } \\
\text { AADTs?* }\end{array}$} & \multirow{2}{*}{\multicolumn{3}{|c|}{$\frac{\mathrm{CV}}{\text { Condition }}$}} & \multirow{3}{*}{$\begin{array}{c}\text { How Close } \\
\text { Are The } \\
\text { CV's?* }\end{array}$} \\
\hline & & \multicolumn{3}{|c|}{ Condition } & & & & & \\
\hline & & 1 & 2 & 3 & & 1 & 2 & 3 & \\
\hline 01 & 119 & 30,180 & 30,111 & 29,681 & $1.68 \%$ & 21.2 & 21.3 & 20.5 & $3.71 \%$ \\
\hline 02 & 223 & 4,474 & 4,486 & 4,447 & $0.88 \%$ & 16.5 & 16.5 & 15.7 & $5.16 \%$ \\
\hline 02 & 65 & 7,382 & 7,370 & 7,330 & $0.70 \%$ & 11.1 & 11.0 & 11.0 & $0.45 \%$ \\
\hline 02 & 9925 & 12,661 & 12,741 & 12,785 & $0.98 \%$ & 15.0 & 14.2 & 13.9 & $7: 63 \%$ \\
\hline 02 & 104 & 22,098 & 22,145 & 22,229 & $0.59 \%$ & 8.0 & 7.8 & 7.8 & $3.09 \%$ \\
\hline 02 & 118 & 22,262 & 22,322 & 22,110 & $0.96 \%$ & 12.6 & 12.5 & 10.9 & $15.96 \%$ \\
\hline 06 & 170 & 5,284 & 5,303 & 5,308 & $0.46 \%$ & 12.3 & 11.9 & 11.7 & $5.04 \%$ \\
\hline 07 & 136 & 6,336 & 6,376 & 6,434 & $1.55 \%$ & 18.6 & 18.0 & 17.5 & $6.23 \%$ \\
\hline 11 & 133 & 28,026 & 28,008 & 27,968 & $0.21 \%$ & 15.4 & 15.5 & 15.1 & $2.45 \%$ \\
\hline 11 & 179 & 54,599 & 54,753 & 54,866 & $0.49 \%$ & 13.7 & 13.7 & 13.8 & $0.95 \%$ \\
\hline 11 & 130 & 110,865 & 110,998 & 110,777 & $0.20 \%$ & 8.9 & 8.9 & 8.8 & $1.36 \%$ \\
\hline 11 & 196 & 154,304 & 154,805 & 155,392 & $0.71 \%$ & 12.2 & 11.8 & 11.4 & $6.84 \%$ \\
\hline 12 & 204 & 28,294 & 28,414 & 28,542 & $0.88 \%$ & 11.7 & 11.5 & 11.3 & $3.89 \%$ \\
\hline 14 & 114 & 14,436 & 14,519 & 14,533 & $0.68 \%$ & 13.6 & 12.8 & 12.6 & $8.10 \%$ \\
\hline 14 & 177 & 33,290 & 33,502 & 33,534 & $0.73 \%$ & 16.6 & 15.9 & 15.7 & $5.86 \%$ \\
\hline 14 & 102 & 40,753 & 40,993 & 41,177 & $1.04 \%$ & 14.4 & 13.8 & 13.5 & $6.89 \%$ \\
\hline 14 & 154 & 44,030 & 44,251 & 44,372 & $0.78 \%$ & 11.6 & 11.0 & 10.3 & $12.33 \%$ \\
\hline 14 & 113 & 45,825 & 46,035 & 46,165 & $0.74 \%$ & 14.0 & 13.3 & 13.1 & $6.64 \%$ \\
\hline 14 & 197 & 47,270 & 47,449 & 47,742 & $1.00 \%$ & 16.1 & 15.6 & 15.2 & $5.86 \%$ \\
\hline 16 & 246 & 7,681 & 7,712 & 7,745 & $0.83 \%$ & 10.4 & 10.0 & 9.8 & $5.82 \%$ \\
\hline 16 & 175 & 39,920 & 40,255 & 40,537 & $1.54 \%$ & 22.4 & 21.4 & 20.9 & $7.32 \%$ \\
\hline
\end{tabular}

* How close are the 3 estimates? The 3 estimates are within X\% of each other.

** For functional class definition, see Table 1. 


\subsection{Empirical Analysis of Variance of Continuous Traffic Monitoring Data}

We also investigate the main contributors to the variance in traffic in terms of the "day of week," "month of year," and "holiday periods" vs. "non-holiday periods." Contributions to the variability for each day of the week were ranked as $1=$ the smallest daily contribution to variability and $7=$ the largest daily contribution to variability. Table 29 is an overall ranking of the days of the week in terms of their contributions to traffic count variability, averaged over all 21 Florida count sites. Table 30 is an overall ranking of the months of the year, in terms of their contributions to traffic count variability.

Similarly, Table 31 presents an overall ranking of the days of the week in terms of their contributions to traffic classification variability. The contributions to traffic classification variability differ among vehicle classes. For example, for motorcycles (Vehicle Class 1), buses (4), and single units (7), the larger daily contributor to variability tends to be weekdays rather than weekend days. For passenger cars (2), other 2-axle 4-tire single-unit vehicles (3), single units (5 and 6), and single-trailer trucks ( 8 and 9), the larger daily contributors to variability tend to be weekend days rather than weekdays. For multi-trailers trucks $(11,12$, and 13), the larger daily contributor to variability tends to be weekdays rather than weekend days for Week Type 1 (Monday through Friday) and for Week Type 2 (Monday through Thursday), except for vehicle class 12 (6axle, multi-trailer trucks).

Similarly, Table 32 presents an overall ranking of the months of the year in terms of their contributions to traffic classification variability. Again, the "month-of-year" contributions to the variability in traffic classification data differ among vehicle classes. For vehicle classes $1,4,7,11$, 12,13 , and 14 , the larger daily contributor to the variability in traffic classification data tends to be "non-holiday period days" rather than the "all holiday period days." The reverse is true for vehicle classes $2,3,5,6,8,9$, and 10 . 
Table 29.

Overall Ranking for Contributions to Variability of Traffic Count Data by Days of Week (based on 21 Florida count sites)

\begin{tabular}{||l|l|}
\hline 1 (smallest contributor to variability) & Tuesday \\
\hline 2 & Monday \\
\hline 3 & Wednesday \\
\hline 4 & Thursday \\
\hline 5 & Saturday \\
\hline 6 & Friday \\
\hline 7 (largest contributor to variability) & Sunday \\
\hline
\end{tabular}

Table 30.

Overall Ranking for Contributions to Variability of Traffic Count Data by Months of Year

(based on 21 Florida count sites)

\begin{tabular}{||l|l|}
\hline 1 (smallest contributor to variability) & June \\
\hline 2 & August \\
\hline 3 & May \\
\hline 4 & October \\
\hline 5 & February \\
\hline 6 & April \\
\hline 7 & July \\
\hline 8 & September \\
\hline 9 & March \\
\hline 10 & November \\
\hline 11 & January \\
\hline 12 (largest contributor to variability) & December \\
\hline
\end{tabular}


Table 31.

Overall Ranking for Contributions to Variability of Traffic Classification Data by Days of Week

(based on 8 Florida Classification Sites)

\begin{tabular}{|l|ccccccc||}
\hline & \multicolumn{7}{|c|}{ Day of Week } \\
\hline Vehicle Class & Sun & Mon & Tue & Wed & Thu & Fri & Sat \\
\hline (1) Motorcycles & 2 & 3 & 4 & 7 & 5 & 6 & 1 \\
(2) Passenger Cars & 7 & 4 & 1 & 2 & 3 & 6 & 5 \\
(3) Other 2 Axle, 4 Tire, S Unit & 7 & 3 & 1 & 2 & 4 & 5 & 5 \\
(4) Buses & 2 & 4 & 6 & 3 & 7 & 4 & 1 \\
(5) 2 Axle, 6 Tire, S Unit & 7 & 3 & 4 & 2 & 5 & 1 & 6 \\
(6) 3 Axle, S Unit & 7 & 3 & 1 & 4 & 5 & 2 & 6 \\
(7) 4+ Axle, S Unit & 2 & 4 & 5 & 7 & 6 & 3 & 1 \\
(8) 4- Axle, S Trailer & 7 & 3 & 1 & 2 & 4 & 5 & 6 \\
(9) 5 Axle, S Trailer & 7 & 5 & 2 & 3 & 4 & 1 & 6 \\
(10) 6 Axle, S Trailer & 6 & 6 & 4 & 2 & 5 & 2 & 1 \\
(11) 5- Axle, M Trailers & 2 & 3 & 4 & 6 & 5 & 7 & 1 \\
(12) 6 Axle, M Trailers & 4 & 2 & 2 & 6 & 5 & 7 & 1 \\
(13) 7+ Axle, M Trailers & 3 & 5 & 5 & 7 & 2 & 4 & 1 \\
(14) Unclassified/Other & 4 & 4 & 2 & 6 & 3 & 7 & 1 \\
\hline COMBINED* & 7 & 4 & 1 & 2 & 3 & 6 & 5 \\
\hline
\end{tabular}

* From Result 22 of [2] using only the 8 classification sites. 
Table 32.

Overall Ranking for Contributions to

Variability of Traffic Classification Data by Months of Year

(Based on 8 Florida Classification Sites)

\begin{tabular}{|c|c|c|c|c|c|c|c|c|c|c|c|c|}
\hline \multirow[b]{2}{*}{ Vehicle Class } & \multicolumn{12}{|c|}{ Month of Year } \\
\hline & Jan & Feb & Mar & Apr & May & Jun & Jul & Aug & Sep & Oct & Nov & Dec \\
\hline (1) Motorcycles & 7 & 7 & 12 & 11 & 4 & 5 & 2 & 1 & 3 & 10 & 5 & 7 \\
\hline (2) Passenger Cars & 12 & 5 & 6 & 2 & 4 & 3 & 8 & 1 & 9 & 6 & 11 & 10 \\
\hline (3) Other 2 Axle, 4 Tire, S Unit & 11 & 9 & 12 & 6 & 3 & 2 & 7 & 1 & 4 & 9 & 7 & 4 \\
\hline (4) Buses & 11 & 7 & 12 & 10 & 5 & 1 & 2 & 3 & 4 & 8 & 6 & 9 \\
\hline (5) 2 Axle, 6 Tire, $S$ Unit & 11 & 5 & 8 & 2 & 8 & 4 & 3 & 1 & 5 & 10 & 12 & 7 \\
\hline (6) 3 Axle, S Unit & 8 & 11 & 5 & 4 & 12 & 2 & 10 & 1 & 6 & 9 & 7 & 3 \\
\hline (7) $4+$ Axle, S Unit & 10 & 12 & 8 & 1 & 5 & 4 & 7 & 3 & 2 & 6 & 9 & 10 \\
\hline (8) 4-Axle, S Trailer & 11 & 6 & 8 & 4 & 7 & 1 & 2 & 2 & 5 & 12 & 10 & 8 \\
\hline (9) 5 Axle, $S$ Trailer & 6 & 5 & 11 & 4 & 12 & 3 & 8 & 1 & 2 & 10 & 7 & 8 \\
\hline (10) 6 Axle, S Trailer & 5 & 4 & 6 & 3 & 10 & 12 & 11 & 8 & 1 & 1 & 8 & 7 \\
\hline (11) 5-Axle, M Trailers & 1 & 2 & 10 & 6 & 3 & 9 & 8 & 7 & 12 & 11 & 5 & 4 \\
\hline (12) 6 Axle, M Trailers & 10 & 8 & 4 & 12 & 9 & 4 & 3 & 6 & 2 & 1 & 11 & 7 \\
\hline (13) 7+ Axle, M Trailers & 6 & 4 & 7 & 1 & 2 & 9 & 7 & 2 & 4 & 12 & 11 & 10 \\
\hline (14) Unclassified/Other & 7 & 11 & 6 & 3 & 2 & 4 & 5 & 1 & 8 & 12 & 8 & 8 \\
\hline COMBINED* & 12 & 6 & 10 & 3 & 5 & 1 & 9 & 2 & 7 & 4 & 7 & 11 \\
\hline
\end{tabular}

* From Result 23 of Task II Report using only the 6 classification sites $(9925,170,114,177,113$, and 175) that had classification data for all twelve months of 1994. 


\section{SUMMARY REMARKS \\ Analysis of Variance of Continuous Traffic Data}

The larger contributors to traffic count variability are the weekend days rather than the weekdays, the winter months rather than the summer months, and the "all holiday period" days rather than the "non-holiday period" days.

Relative to "day of week," "month of year," "weekday vs weekend day," and "holiday period" and "non-holiday period," the larger daily contributors to the variability in the daily traffic classification data differ among vehicle classes.

These results provide preliminary guidance for one to consider a larger role for sampling in traffic monitoring. In short, one should sample more where there is greater variability, especially if technology permits.

\section{PRECISION OF SHORT-TERM TRAFFIC MONITORING DATA}

We conducted simulation studies to study the extent to which the variability in the continuous traffic data is transferred to, and affects the precision of, short-term monitoring data. In these studies, we created seasonal (monthly) factors and day-of-week factors from the continuous monitoring sites. Given these factors, we considered that we have only one day's ( 24 hour period) worth of data from each of the continuous monitoring sites. That is, we assumed that the site is a short-term monitored site. Given the factors and the 24 hour period of data, we calculated annual estimates of traffic characteristics (i.e., AADT, AADT by vehicle class, daily ESAL and weight per vehicle). Our interest is in the precision of these estimates. To get an appropriate indication of this precision, we calculated an annual estimate based on each day of available data for each site. Thus, for a given continuously monitored site and with $N$ days of data, we have $N$ different annual estimates, each obtained by treating the site as a short-term monitored site. We also have the original estimate obtained by treating the site as a continuously monitored site. For each site, we compute the average of the squared deviations, where a deviation is the difference in the original annual estimate as a continuously monitored site and an annual estimate obtained as though the site were a short-term monitored site. If these deviations are small, then we may surmise that the results 
obtained from the short-term monitored sites are as good as those from the continuously monitored sites. Conversely, as these deviations increase we may be more concerned about the precision of estimates obtained from short-term monitored sites. The original measures of precision given in Table 33 are obtained by dividing the CVs in Table 5 by the

$$
\sqrt{\text { number of days }} \text {. }
$$

By doing this, we are treating the original observations as a random sample, AADT as a sample mean, and "original" estimated precision as the estimated standard error of the sample mean.

Monthly (seasonal) factors and day-of-week factors were calculated based on procedures recommended by the Traffic Monitoring Guide [1], and are described in [7]. Empirical results for count data are in Table 33. In general, empirical results should be accepted with caution. The empirical results reported herein are no exception, especially because we view data from a small number of sites and only from two states.

In Table 33, the first AADT estimate is the original estimate, by treating the site as a continuously monitored site. The other two AADT estimates are averages of the estimates computed by treating the site as a short-term monitored site. Based on the maximum ratio [6], we observed that all estimates at a given site are, on average, within $2 \%$ of each other.

When each site is treated as a short-term monitored site and an estimate for AADT is calculated, these simulated estimates tend to be higher, on average, than the original estimates in almost all cases. This may suggest some (slight) positive bias in the simulated estimates. That is, adjustments of short-term monitored data by day-of-the-week and month-of-the-year factors appear to over-estimate the typical traffic and loading patterns. Further research should be undertaken based on data from more sites to assess whether and why estimates from short-term monitored sites tend to be positively biased.

Not surprisingly, the original estimates (continuous monitoring) appear to be more precise, on average, than the simulated estimates (short-term monitored). This apparent decrease in the precision of the simulated estimates is, in part, very likely due to possible bias. 
Table 33.

Precision of Original and Simulated AADTs

(Based on 20 Florida Count Sites)

\begin{tabular}{|c|c|c|c|c|c|c|c|c|c|c|c|}
\hline \multirow[b]{2}{*}{ Grp } & \multirow[b]{2}{*}{ Site } & \multirow[b]{2}{*}{$\begin{array}{l}\text { Number } \\
\text { of Days }\end{array}$} & \multicolumn{2}{|c|}{ Original Estimates } & \multicolumn{3}{|c|}{$\begin{array}{c}\text { Simulated Estimates } \\
\text { (Factors used contain information from site being } \\
\text { estimated.) }\end{array}$} & \multicolumn{3}{|c|}{$\begin{array}{c}\text { Simulated Estimates } \\
\text { (Factors used do not contain information from } \\
\text { site being estimated.) } \\
\end{array}$} & \multirow{2}{*}{$\begin{array}{c}\text { Maximum Ratio } \\
\text { (The } 3 \text { Estimates are } \\
\text { within X\% of each } \\
\text { other.) }\end{array}$} \\
\hline & & & $\begin{array}{c}\text { Estimated } \\
\text { AADT }\end{array}$ & $\begin{array}{l}\text { Estimated } \\
\text { Precision } \\
\end{array}$ & $\begin{array}{c}\text { Estimated } \\
\text { AADT } \\
\end{array}$ & $\begin{array}{c}\text { Square Root } \\
\text { of MSE }\end{array}$ & $\begin{array}{l}\text { Estimated } \\
\text { Precision }\end{array}$ & $\begin{array}{c}\text { Estimated } \\
\text { AADT }\end{array}$ & $\begin{array}{c}\text { Square Root } \\
\text { of MSE }\end{array}$ & $\begin{array}{l}\text { Estimated } \\
\text { Precision }\end{array}$ & \\
\hline 2 & 65 & 322 & 7382 & $0.61 \%$ & 7,502 & 1,037 & $13.8 \%$ & 7,522 & 1,181 & $15.7 \%$ & $1.90 \%$ \\
\hline 2 & 104 & 347 & 22098 & $0.43 \%$ & 22,375 & 1,770 & $7.9 \%$ & 22,419 & 1,979 & $8.8 \%$ & $1.45 \%$ \\
\hline 2 & 118 & 345 & 22262 & $0.68 \%$ & 22,490 & 2,108 & $9.4 \%$ & 22,531 & 2,266 & $10.1 \%$ & $1.21 \%$ \\
\hline 2 & 136 & 263 & 6336 & $1.15 \%$ & 6,363 & 783 & $12.3 \%$ & 6,367 & 890 & $14.0 \%$ & $0.49 \%$ \\
\hline 2 & 170 & 353 & 5284 & $0.65 \%$ & 5,311 & 354 & $6.7 \%$ & 5,316 & 390 & $7.3 \%$ & $0.61 \%$ \\
\hline 2 & 223 & 231 & 4474 & $1.09 \%$ & 4,528 & 615 & $13.6 \%$ & 4,537 & 673 & $14.8 \%$ & $1.41 \%$ \\
\hline 2 & 9925 & 308 & 12661 & $0.85 \%$ & 12,671 & 1,142 & $9.0 \%$ & 12,673 & 1,250 & $9.9 \%$ & $0.09 \%$ \\
\hline 3 & 130 & 341 & 110865 & $0.48 \%$ & 111,625 & 6,635 & $5.9 \%$ & 111,963 & 7,724 & $6.9 \%$ & $0.99 \%$ \\
\hline 3 & 133 & 283 & 28026 & $0.92 \%$ & 27,949 & 3,085 & $11.0 \%$ & 27,897 & 3,579 & $12.8 \%$ & $0.46 \%$ \\
\hline 3 & 179 & 210 & 54599 & $0.95 \%$ & 54,870 & 4,569 & $8.3 \%$ & 54,940 & 5,357 & $9.8 \%$ & $0.62 \%$ \\
\hline 3 & 196 & 252 & 154304 & $0.77 \%$ & 155,952 & 14,598 & $9.4 \%$ & 156,704 & 19,127 & $12.2 \%$ & $1.56 \%$ \\
\hline 4 & 102 & 278 & 40753 & $0.86 \%$ & 40,807 & 2,478 & $6.1 \%$ & 40,822 & 2,617 & $6.4 \%$ & $0.17 \%$ \\
\hline 4 & 113 & 326 & 45825 & $0.78 \%$ & 45,960 & 2,474 & $5.4 \%$ & 45,980 & 2,599 & $5.7 \%$ & $0.34 \%$ \\
\hline 4 & 114 & 267 & 14436 & $0.83 \%$ & 14,605 & 1,009 & $6.9 \%$ & 14,642 . & 1,085 & $7.4 \%$ & $1.43 \%$ \\
\hline 4 & 154 & 220 & 44030 & $0.78 \%$ & 44,123 & 2,992 & $6.8 \%$ & 44,124 & 3,297 & $7.5 \%$ & $0.21 \%$ \\
\hline 4 & 175 & 342 & 39920 & $1.21 \%$ & 39,438 & 5,066 & $12.8 \%$ & 39,364 & 5,585 & $14.2 \%$ & $1.41 \%$ \\
\hline 4 & 177 & 333 & 33290 & $0.91 \%$ & 33,358 & 2,329 & $7.0 \%$ & 33,394 & 2,480 & $7.4 \%$ & $0.31 \%$ \\
\hline 4 & 197 & 212 & 47270 & $1.11 \%$ & 47,020 & 2,882 & $6.1 \%$ & 46,992 & 3,082 & $6.6 \%$ & $0.59 \%$ \\
\hline 4 & 204 & 212 & 28294 & $0.80 \%$ & 28,646 & 3,229 & $11.3 \%$ & 28,674 & 3,590 & $12.5 \%$ & $1.34 \%$ \\
\hline 4 & 246 & 278 & 7681 & $0.62 \%$ & 7,750 & 577 & $7.4 \%$ & 7,757 & 638 & $8.2 \%$ & $0.99 \%$ \\
\hline
\end{tabular}

Grp: $\quad 1=$ Rural interstate $\quad 2=$ Rural others $\quad 3=$ Urban Interstate $\quad 4=$ Urban others 
For classification data, we made use of 1994 classification count data for eight of Florida's continuously monitored classification sites as well as nine of Washington's continuously monitored weigh-in-motion sites. Data from Florida's classification sites include all vehicles counted at a site while data from Washington's WIM sites are limited to vehicle classes 3 through 14. Results from [7] are given in Tables 34 and 35.

Empirical results for classification data show that for a particular vehicle class, the original estimate of AADT, treating the sites as continuously monitored sites, is quite close to, but usually smaller than, the simulated estimate of AADT, treating the sites as short-term monitored sites. As expected, the estimates of AADT based on treating the sites as continuously monitored sites are more precise than the estimates of AADT based on treating the sites as short-term monitored sites.

Similar results are found in ESAL estimates. Results from [7] are given in Table 36. To avoid the problem of small sample size, we grouped trucks into the following vehicle classes:

\begin{tabular}{l|l}
\hline Grouped Vehicle Class & Original Vehicle Class \\
\hline G1 Passenger Vehicles & (3) Other 2 Axle, 4 Tire, Single Unit \\
G2 Single-Unit Trucks & (4) Buses \\
& (5) 2 Axle, 6 Tire, Single Unit \\
& (6) 3 Axle, Single Unit \\
& $(7) 4^{+}$Axle, Single Unit \\
G3 Single-Trailer Trucks & $(8) 4 \cdot$ Axle, Single Trailer \\
& $(9) 5$ Axle, Single Trailer \\
G4 Multi-Trailer Trucks & (10) 6 Axle, Single Trailer \\
G5 Very Large Trucks & (11) 5 Axle, Multi-Trailer \\
G6 Unknown Vehicle & $(12) 6$ Axle, Multi-Trailer \\
\hline
\end{tabular}

In reality, ESAL or weight estimates that are calculated based on 24- or 48-hours of data are reported unadjusted. That is, short-term WIM data are not adjusted by day-of-the-week and month-of-the-year factors. Since our results show that traffic loading varies substantially by day of the week and by month of the year, we adjust the short-term WIM data in a way similar to that of short-term traffic count data. When a site is treated as a short-term monitored site and daily ESAL estimate per vehicle is simulated, the simulated estimates are almost always higher than the original estimates (about $93 \%$ of the time). This suggests that there may be some slight positive bias present in the simulated ESAL estimates. The precision of the estimates is also much better, 
on average, for the original ESAL estimates than for the simulated estimates (about $96 \%$ of the time).

Annualizing short-term WIM data by day-of-the-week and month-of-the-year factors produces reasonable estimates for three truck groups - single-trailer trucks, multi-trailer trucks, and 7-axle multi-trailer trucks. However, this approach produces ESAL and daily weight estimates for the remaining truck groups that have unacceptably low precision (Table 36). This finding might be attributable to the large variability observed in the daily ESALs for these groups. Data from three Washington WIM sites were used to illustrate how variability in daily loadings can influence the reliability of simulated estimates (Table 37). Data from more sites across a sample of representative states should be analyzed to confirm these findings. Furthermore, research is needed to quantify the impact of reporting unadjusted short-term WIM data. Finally, if this impact is consequential, then a procedure should be developed to adjust short-term WIM data to more accurately reflect temporal variations. 
Table 34. Precision of Original and Simulated AADTs by Vehicle Classes for 8 Florida Classification Sites

\begin{tabular}{|c|c|c|c|c|c|c|c|c|}
\hline \multirow[b]{2}{*}{ Group } & \multirow[b]{2}{*}{ Site } & \multirow[b]{2}{*}{$\begin{array}{l}\text { Number } \\
\text { of Days }\end{array}$} & \multirow[b]{2}{*}{ Vehicle Class } & \multicolumn{2}{|c|}{ Original Estimates } & \multicolumn{3}{|c|}{$\begin{array}{c}\text { Simulated Estimates } \\
\text { (Factors do not contain information from site } \\
\text { being estimated.) }\end{array}$} \\
\hline & & & & $\begin{array}{c}\text { Estimated } \\
\text { AADT(i) }\end{array}$ & $\begin{array}{l}\text { Estimated } \\
\text { Precision }\end{array}$ & $\begin{array}{c}\text { Estimated } \\
\text { AADT(i) }\end{array}$ & $\begin{array}{l}\text { Square Root } \\
\text { of MSE }\end{array}$ & $\begin{array}{l}\text { Estimated } \\
\text { Precision }\end{array}$ \\
\hline \multirow[t]{14}{*}{2} & 9925 & 307 & (1) Motorcycles & 12 & $14.2 \%$ & 34 & 108.37 & $222.7 \%$ \\
\hline & & & (2) Passenger Cars & 10,538 & $1.2 \%$ & 10,504 & $1,926.38$ & $18.3 \%$ \\
\hline & & & (3) Other 2 Axle, 4 Tire, $S$ Unit & 1,737 & $1.4 \%$ & 1,722 & 377.56 & $21.9 \%$ \\
\hline & & & (4) Buses & 8 & $3.0 \%$ & 10 & 6.80 & $71.0 \%$ \\
\hline & & & (5) 2 Axle, 6 Tire, S Unit & 176 & $2.8 \%$ & 190 & 81.53 & $43.0 \%$ \\
\hline & & & (6) 3 Axle, S Unit & 59 & $2.9 \%$ & 64 & 31.32 & $48.7 \%$ \\
\hline & & & (7) $4^{+}$Axle, S Unit & 8 & $7.2 \%$ & 14 & 22.97 & $159.6 \%$ \\
\hline & & & (8) $4^{-}$Axle, $S$ Trailer & 71 & $3.0 \%$ & 69 & 38.55 & $55.8 \%$ \\
\hline & & & (9) 5 Axle, $S$ Trailer & 95 & $2.5 \%$ & 98 & 34.15 & $35.0 \%$ \\
\hline & & & (10) $6^{+}$Axle, S Trailer & 2 & $5.5 \%$ & 2 & 2.00 & $97.9 \%$ \\
\hline & & & (11) 5 Axle, $M$ Trailers & 1 & $8.0 \%$ & - & -- & - \\
\hline & & & (12) 6 Axle, $M$ Trailers & -- & - & - & .. & - \\
\hline & & & (13) $7^{+}$Axle, M Trailers & 2 & $6.2 \%$ & 3 & 7.02 & $212.4 \%$ \\
\hline & & & (14) Unclassified/Other & 200 & $3.6 \%$ & 313 & 290.78 & $92.8 \%$ \\
\hline \multirow[t]{14}{*}{2} & 170 & 353 & (1) Motorcycles & 7 & $6.9 \%$ & 17 & 28.14 & $167.6 \%$ \\
\hline & & & (2) Passenger Cars & 4,080 & $0.6 \%$ & 4,116 & 399.52 & $9.7 \%$ \\
\hline & & & (3) Other 2 Axle, 4 Tire, S Unit & 749 & $1.1 \%$ & 754 & 104.94 & $13.9 \%$ \\
\hline & & & (4) Buses & 3 & $4.4 \%$ & 3 & 2.40 & $84.9 \%$ \\
\hline & & & (5) 2 Axle, 6 Tire, S Unit & 9 & $3.2 \%$ & 9 & 4.40 & $50.4 \%$ \\
\hline & & & (6) 3 Axle, $S$ Unit & 69 & $2.7 \%$ & 85 & 84.65 & $99.2 \%$ \\
\hline & & & (7) $4^{+}$Axle, S Unit & 11 & $5.8 \%$ & 14 & 18.58 & $135.5 \%$ \\
\hline & & & (8) $4^{-}$Axle, S Trailer & 72 & $1.6 \%$ & 97 & 69.28 & $71.4 \%$ \\
\hline & & & (9) 5 Axle, $S$ Trailer & 45 & $2.4 \%$ & 45 & 15.47 & $34.4 \%$ \\
\hline & & & (10) $6^{+}$Axle, $S$ Trailer & 4 & $4.0 \%$ & 4 & 2.79 & $74.6 \%$ \\
\hline & & & (11) 5 Axle, $M$ Trailers & - & - & -- & -- & - \\
\hline & & & (12) 6 Axle, M Trailers & -- & - & -- & -- & -- \\
\hline & & & (13) $7^{+}$Axle, M Trailers & 12 & $5.1 \%$ & 13 & 15.24 & $114.8 \%$ \\
\hline & & & (14) Unclassified/Other & 224 & $4.1 \%$ & 264 & 245.07 & $92.9 \%$ \\
\hline
\end{tabular}


Table 34. (continued)

\begin{tabular}{|c|c|c|c|c|c|c|c|c|}
\hline \multirow[b]{2}{*}{ Group } & \multirow[b]{2}{*}{ Site } & \multirow[b]{2}{*}{$\begin{array}{l}\text { Number } \\
\text { of Days }\end{array}$} & \multirow[b]{2}{*}{ Vehicle Class } & \multicolumn{2}{|c|}{ Original Estimates } & \multicolumn{3}{|c|}{$\begin{array}{c}\text { Simulated Estimates } \\
\text { (Factors do not contain information from site } \\
\text { being estimated.) }\end{array}$} \\
\hline & & & & $\begin{array}{l}\text { Estimated } \\
\text { AADT(i) }\end{array}$ & $\begin{array}{l}\text { Estimated } \\
\text { Precision }\end{array}$ & $\begin{array}{c}\text { Estimated } \\
\text { AADT(i) }\end{array}$ & $\begin{array}{c}\text { Square Root } \\
\text { of MSE }\end{array}$ & $\begin{array}{l}\text { Estimated } \\
\text { Precision }\end{array}$ \\
\hline \multirow[t]{14}{*}{4} & 113 & 323 & (1) Motorcycles & 23 & $2.9 \%$ & 101 & 127.38 & $126.1 \%$ \\
\hline & & & (2) Passenger Cars & 39,755 & $0.7 \%$ & 39,917 & $2,382.29$ & $6.0 \%$ \\
\hline & & & (3) Other 2 Axle, 4 Tire, S Unit & 4,743 & $1.3 \%$ & 4,855 & 610.48 & $12.6 \%$ \\
\hline & & & (4) Buses & 6 & $5.2 \%$ & 18 & 22.13 & $119.9 \%$ \\
\hline & & & (5) 2 Axle, 6 Tire, S Unit & 59 & $3.2 \%$ & 67 & 27.26 & $40.6 \%$ \\
\hline & & & (6) 3 Axle, S Unit & 162 & $2.6 \%$ & 215 & 134.58 & $62.5 \%$ \\
\hline & & & (7) $4^{+}$Axle, S Unit & 25 & $6.7 \%$ & 34 & 34.48 & $102.6 \%$ \\
\hline & & & (8) $4^{-}$Axle, S Trailer & 363 & $1.9 \%$ & 384 & 89.45 & $23.3 \%$ \\
\hline & & & (9) 5 Axle, S Trailer & 79 & $2.5 \%$ & 81 & 17.79 & $21.9 \%$ \\
\hline & & & (10) $6^{+}$Axle, S Trailer & 4 & $4.6 \%$ & 5 & 4.25 & $85.5 \%$ \\
\hline & & & (11) 5 Axle, M Trailers & 1 & $8.3 \%$ & 1 & 1.24 & $167.3 \%$ \\
\hline & & & (12) 6 Axle, M Trailers & - & - & - & -- & - \\
\hline & & & (13) $7^{+}$Axle, $M$ Trailers & 6 & $6.7 \%$ & 16 & 34.84 & $212.8 \%$ \\
\hline & & & (14) Unclassified/Other & 642 & $1.2 \%$ & 739 & 220.49 & $29.9 \%$ \\
\hline \multirow[t]{14}{*}{4} & 114 & 266 & (1) Motorcycles & 37 & $11.0 \%$ & 196 & 579.05 & $294.9 \%$ \\
\hline & & & (2) Passenger Cars & 12,390 & $0.7 \%$ & 12,604 & 940.57 & $7.5 \%$ \\
\hline & & & (3) Other 2 Axle, 4 Tire, S Unit & 1,533 & $1.5 \%$ & 1,619 & 208.61 & $12.9 \%$ \\
\hline & & & (4) Buses & 4 & $10.6 \%$ & 15 & 47.92 & $314.1 \%$ \\
\hline & & & (5) 2 Axle, 6 Tire, S Unit & 27 & $4.4 \%$ & 26 & 13.25 & $51.6 \%$ \\
\hline & & & (6) 3 Axle, S Unit & 108 & $3.6 \%$ & 113 & 54.19 & $48.1 \%$ \\
\hline & & & (7) $4^{+}$Axle, S Unit & 5 & $10.6 \%$ & 6 & 9.88 & $164.0 \%$ \\
\hline & & & (8) $4^{\circ}$ Axle, S Trailer & 158 & $1.4 \%$ & 185 & 84.59 & $45.7 \%$ \\
\hline & & & (9) 5 Axle, S Trailer & 49 & $3.0 \%$ & 49 & 13.15 & $26.6 \%$ \\
\hline & & & (10) $6^{+}$Axle, S Trailer & 6 & $4.4 \%$ & 6 & 4.23 & $68.4 \%$ \\
\hline & & & (11) 5 Axle, M Trailers & - & - & + & -- & -- \\
\hline & & & (12) 6 Axle, M Trailers & - & - & - & - & $\cdots$ \\
\hline & & & (13) $7^{+}$Axle, M Trailers & -- & - & $\cdots$ & - & -- \\
\hline & & & (14) Unclassified/Other & 129 & $3.0 \%$ & 149 & 100.87 & $67.7 \%$ \\
\hline
\end{tabular}


Table 34. (continued)

\begin{tabular}{|c|c|c|c|c|c|c|c|c|}
\hline \multirow[b]{2}{*}{ Group } & \multirow[b]{2}{*}{ Site } & \multirow[b]{2}{*}{$\begin{array}{l}\text { Number } \\
\text { of Days }\end{array}$} & \multirow[b]{2}{*}{ Vehicle Class } & \multicolumn{2}{|c|}{ Original Estimates } & \multicolumn{3}{|c|}{$\begin{array}{c}\text { Simulated Estimates } \\
\text { (Factors do not contain information from site } \\
\text { being estimated.) }\end{array}$} \\
\hline & & & & $\begin{array}{l}\text { Estimated } \\
\text { AADT(i) }\end{array}$ & $\begin{array}{l}\text { Estimated } \\
\text { Precision }\end{array}$ & $\begin{array}{l}\text { Estimated } \\
\text { AADT(i) }\end{array}$ & $\begin{array}{l}\text { Square Root } \\
\text { of MSE }\end{array}$ & $\begin{array}{l}\text { Estimated } \\
\text { Precision }\end{array}$ \\
\hline \multirow[t]{14}{*}{4} & 175 & 342 & (1) Motorcycles & 38 & $5.5 \%$ & 195 & 403.99 & $207.7 \%$ \\
\hline & & & (2) Passenger Cars & 34,830 & $1.2 \%$ & 34,389 & $5,246.37$ & $15.3 \%$ \\
\hline & & & (3) Other 2 Axle, 4 Tire, S Unit & 2,897 & $2.2 \%$ & 2,822 & 783.93 & $27.8 \%$ \\
\hline & & & (4) Buses & 42 & $3.9 \%$ & 132 & 169.32 & $128.4 \%$ \\
\hline & & & (5) 2 Axle, 6 Tire, S Unit & 60 & $2.9 \%$ & 70 & 35.17 & $50.5 \%$ \\
\hline & & & (6) 3 Axle, S Unit & 135 & $5.1 \%$ & 158 & 232.08 & $146.8 \%$ \\
\hline & & & (7) $4^{+}$Axle, S Unit & 18 & $8.2 \%$ & 28 & 79.77 & $282.1 \%$ \\
\hline & & & (8) $4^{-}$Axle, $S$ Trailer & 299 & $2.8 \%$ & 296 & 115.07 & $38.9 \%$ \\
\hline & & & (9) 5 Axle, S Trailer & 231 & $1.6 \%$ & 289 & 158.02 & $54.6 \%$ \\
\hline & & & (10) $6^{+}$Axle, S Trailer & 5 & $8.5 \%$ & 5 & 12.69 & $234.4 \%$ \\
\hline & & & (11) 5 Axle, $M$ Trailers & 1 & $6.9 \%$ & 1 & 2.09 & $153.6 \%$ \\
\hline & & & (12) 6 Axle, $M$ Trailers & 1 & $7.6 \%$ & 1 & 0.90 & $145.9 \%$ \\
\hline & & & (13) $7^{+}$Axle, M Trailers & 125 & $9.5 \%$ & 209 & 508.79 & $243.9 \%$ \\
\hline & & & (14) Unclassified/Other & 1,241 & $6.8 \%$ & 1,276 & $1,566.74$ & $122.8 \%$ \\
\hline \multirow[t]{14}{*}{4} & 177 & 284 & (1) Motorcycles & 79 & $7.4 \%$ & 384 & 716.38 & $186.6 \%$ \\
\hline & & & (2) Passenger Cars & 28,661 & $0.9 \%$ & 28,716 & $1,926.80$ & $6.7 \%$ \\
\hline & & & (3) Other 2 Axle, 4 Tire, S Unit & 3,189 & $1.7 \%$ & 3,234 & 585.82 & $18.1 \%$ \\
\hline & & & (4) Buses & 21 & $2.8 \%$ & 70 & 69.11 & $98.3 \%$ \\
\hline & & & (5) 2 Axle, 6 Tire, S Unit & 53 & $3.3 \%$ & 68 & 40.89 & $59.8 \%$ \\
\hline & & & (6) 3 Axle, S Unit & 93 & $3.8 \%$ & 126 & 120.51 & $95.8 \%$ \\
\hline & & & (7) $4^{+}$Axle, S Unit & 18 & $3.8 \%$ & 35 & 38.51 & $108.8 \%$ \\
\hline & & & (8) $4^{\circ}$ Axle, $S$ Trailer & 331 & $2.1 \%$ & 353 & 79.67 & $22.6 \%$ \\
\hline & & & (9) 5 Axle, S Trailer & 215 & $3.3 \%$ & 220 & 85.54 & $38.9 \%$ \\
\hline & & & (10) $6^{+}$Axle, S Trailer & 10 & $4.0 \%$ & 11 & 6.28 & $58.8 \%$ \\
\hline & & & (11) $5^{-}$Axle, M Trailers & 4 & $5.1 \%$ & 2 & 2.91 & $125.6 \%$ \\
\hline & & & (12) 6 Axle, M Trailers & 1 & $5.5 \%$ & 1 & 1.36 & $110.1 \%$ \\
\hline & & & (13) $7^{+}$Axle, $M$ Trailers & 199 & $7.1 \%$ & 729 & $1,841.07$ & $252.5 \%$ \\
\hline & & & (14) Unclassified/Other & 664 & $3.2 \%$ & 742 & 411.72 & $55.5 \%$ \\
\hline
\end{tabular}

--means estimate of AADT $(i)$ was at or near zero 
Table 34. (continued)

\begin{tabular}{|c|c|c|c|c|c|c|c|c|}
\hline \multirow[b]{2}{*}{ Group } & \multirow[b]{2}{*}{ Site } & \multirow[b]{2}{*}{$\begin{array}{l}\text { Number } \\
\text { of Days }\end{array}$} & \multirow[b]{2}{*}{ Vehicle Class } & \multicolumn{2}{|c|}{ Original Estimates } & \multicolumn{3}{|c|}{$\begin{array}{c}\text { Simulated Estimates } \\
\begin{array}{c}\text { (Factors do not contain information from site } \\
\text { being estimated.) }\end{array}\end{array}$} \\
\hline & & & & $\begin{array}{c}\text { Estimated } \\
\text { AADT(i) } \\
\end{array}$ & $\begin{array}{c}\text { Estimated } \\
\text { Precision }\end{array}$ & $\begin{array}{c}\text { Estimated } \\
\text { AADT(i) }\end{array}$ & $\begin{array}{c}\text { Square Root } \\
\text { of MSE }\end{array}$ & $\begin{array}{l}\text { Estimated } \\
\text { Precision }\end{array}$ \\
\hline \multirow[t]{14}{*}{4} & 197 & 212 & (1) Motorcycles & 350 & $12.4 \%$ & 554 & $1,030.41$ & $186.1 \%$ \\
\hline & & & (2) Passenger Cars & 41,385 & $1.0 \%$ & 41,517 & $2,288.99$ & $5.5 \%$ \\
\hline & & & (3) Other 2 Axle, 4 Tire, $S$ Unit & 3,853 & $2.2 \%$ & 3,723 & 537.17 & $14.4 \%$ \\
\hline & & & (4) Buses & 46 & $10.3 \%$ & 58 & 97.81 & $167.8 \%$ \\
\hline & & & (5) 2 Axle, 6 Tire, S Unit & 90 & $4.1 \%$ & 96 & 48.60 & $50.9 \%$ \\
\hline & & & (6) 3 Axle, S Unit & 203 & $3.0 \%$ & 230 & 76.79 & $33.5 \%$ \\
\hline & & & (7) $4^{+}$Axle, S Unit & 11 & $7.0 \%$ & 13 & 16.00 & $122.4 \%$ \\
\hline & & & (8) $4^{-}$Axle, S Trailer & 375 & $2.6 \%$ & 366 & 69.85 & $19.1 \%$ \\
\hline & & & (9) 5 Axle, S Trailer & 159 & $3.2 \%$ & 160 & 29.84 & $18.7 \%$ \\
\hline & & & (10) $6^{+}$Axle, S Trailer & 4 & $5.2 \%$ & 5 & 3.30 & $72.1 \%$ \\
\hline & & & (11) 5 Axle, M Trailers & 13 & $3.9 \%$ & 30 & 26.85 & $89.6 \%$ \\
\hline & & & (12) 6 Axle, $M$ Trailers & 2 & $6.4 \%$ & 2 & 1.55 & $93.6 \%$ \\
\hline & & & (13) $7^{+}$Axle, M Trailers & -- & $21.3 \%$ & 1 & 2.42 & $440.5 \%$ \\
\hline & & & (14) Unclassified/Other & 782 & $3.8 \%$ & 834 & 518.46 & $62.2 \%$ \\
\hline \multirow[t]{14}{*}{4} & 246 & 277 & (1) Motorcycles & 4 & $4.7 \%$ & 12 & 17.25 & $138.9 \%$ \\
\hline & & & (2) Passenger Cars & 5,816 & $0.6 \%$ & 5,904 & 783.75 & $13.3 \%$ \\
\hline & & & (3) Other 2 Axle, 4 Tire, S Unit & 1,354 & $1.5 \%$ & 1,468 & 458.13 & $31.2 \%$ \\
\hline & & & (4) Buses & 36 & $5.9 \%$ & 71 & 92.47 & $129.4 \%$ \\
\hline & & & (5) 2 Axle, 6 Tire, $S$ Unit & 53 & $3.3 \%$ & 97 & 153.02 & $157.9 \%$ \\
\hline & & & (6) 3 Axle, S Unit & 40 & $3.6 \%$ & 44 & 16.81 & $38.3 \%$ \\
\hline & & & (7) $4^{+}$Axle, S Unit & 3 & $10.9 \%$ & 4 & 7.50 & $194.6 \%$ \\
\hline & & & (8) $4^{-}$Axle, $S$ Trailer & 122 & $1.9 \%$ & 133 & 39.61 & $29.8 \%$ \\
\hline & & & (9) 5 Axle, S Trailer & 113 & $2.9 \%$ & 114 & 27.59 & $24.3 \%$ \\
\hline & & & (10) $6^{+}$Axle, S Trailer & 1 & $7.3 \%$ & 2 & 2.85 & $173.6 \%$ \\
\hline & & & (11) $5^{-}$Axle, $M$ Trailers & - & -- & - & -- & -- \\
\hline & & & (12) 6 Axle, $M$ Trailers & -- & - & -- & -- & -- \\
\hline & & & (13) $7^{+}$Axle, $M$ Trailers & - & -- & 1 & 2.96 & $351.0 \%$ \\
\hline & & & (14) Unclassified/Other & 143 & $2.2 \%$ & 165 & 71.59 & $43.4 \%$ \\
\hline
\end{tabular}


Table 35. Precision of Original and Simulated AADTs by Vehicle Classes for Washington's Weigh-In-Motion Sites

\begin{tabular}{|c|c|c|c|c|c|c|c|c|}
\hline \multirow[b]{2}{*}{ Group } & \multirow[b]{2}{*}{ Site } & \multirow[b]{2}{*}{$\begin{array}{l}\text { Number } \\
\text { of Days }\end{array}$} & \multirow[b]{2}{*}{ Vehicle Class } & \multicolumn{2}{|c|}{ Original Estimates } & \multicolumn{3}{|c|}{$\begin{array}{c}\text { Simulated Estimates } \\
\text { (Factors do not contain information from site } \\
\text { being estimated.) }\end{array}$} \\
\hline & & & & $\begin{array}{l}\text { Estimated } \\
\text { AADT(i) }\end{array}$ & $\begin{array}{l}\text { Estimated } \\
\text { Precision }\end{array}$ & $\begin{array}{c}\text { Estimated } \\
\text { AADT(i) }\end{array}$ & $\begin{array}{l}\text { Square Root } \\
\text { of MSE }\end{array}$ & $\begin{array}{l}\text { Estimated } \\
\text { Precision }\end{array}$ \\
\hline \multirow[t]{12}{*}{2} & P03 & 331 & (3) Other 2 Axle, 4 Tire, S Unit & 14 & $2.8 \%$ & 17 & 9.09 & $54.0 \%$ \\
\hline & & & (4) Buses & 8 & $1.7 \%$ & 12 & 9.94 & $83.0 \%$ \\
\hline & & & (5) 2 Axle, 6 Tire, $S$ Unit & 233 & $1.8 \%$ & 239 & 53.66 & $22.0 \%$ \\
\hline & & & (6) 3 Axle, S Unit & 55 & $3.8 \%$ & 56 & 31.15 & $56.0 \%$ \\
\hline & & & (7) $4^{+}$Axle, S Unit & 17 & $11.8 \%$ & 27 & 57.73 & $214.0 \%$ \\
\hline & & & (8) $4^{\circ}$ Axle, $S$ Trailer & 46 & $3.3 \%$ & 47 & 18.39 & $39.0 \%$ \\
\hline & & & (9) 5 Axle, S Trailer & 257 & $2.4 \%$ & 259 & 68.68 & $27.0 \%$ \\
\hline & & & (10) $6^{+}$Axle, S Trailer & 21 & $4.6 \%$ & 21 & 12.42 & $59.0 \%$ \\
\hline & & & (11) $5^{-}$Axle, M Trailers & 16 & $2.5 \%$ & 18 & 9.13 & $49.0 \%$ \\
\hline & & & (12) 6 Axle, M Trailers & 23 & $2.5 \%$ & 28 & 12.03 & $42.0 \%$ \\
\hline & & & (13) $7^{+}$Axle, $M$ Trailers & 51 & $3.1 \%$ & 53 & 18.20 & $34.0 \%$ \\
\hline & & & (14) Unclassified/Other & 30 & $2.9 \%$ & 35 & 23.13 & $67.0 \%$ \\
\hline \multirow[t]{12}{*}{2} & P05 & 346 & (3) Other 2 Axle, 4 Tire, S Unit & 15 & $3.1 \%$ & 15 & 7.66 & $52.0 \%$ \\
\hline & & & (4) Buses & 1 & $5.8 \%$ & 2 & 2.81 & $161.0 \%$ \\
\hline & & & (5) 2 Axle, 6 Tire, S Unit & 114 & $1.5 \%$ & 118 & 28.91 & $25.0 \%$ \\
\hline & & & (6) 3 Axle, S Unit & 16 & $3.4 \%$ & 21 & 15.42 & $75.0 \%$ \\
\hline & & & (7) $4^{+}$Axle, S Unit & -- & $\cdots$ & 1 & 3.63 & $265.0 \%$ \\
\hline & & & (8) 4 Axle, S Trailer & 27 & $2.6 \%$ & 29 & 10.97 & $38.0 \%$ \\
\hline & & & (9) 5 Axle, $S$ Trailer & 111 & $2.3 \%$ & 112 & 26.05 & $23.0 \%$ \\
\hline & & & (10) $6^{+}$Axle, S Trailer & 13 & $2.9 \%$ & 16 & 10.73 & $68.0 \%$ \\
\hline & & & (11) $5^{\circ}$ Axle, M Trailers & 6 & $2.6 \%$ & 7 & 3.36 & $51.0 \%$ \\
\hline & & & (12) 6 Axle, M Trailers & 21 & $1.9 \%$ & 26 & 14.89 & $57.0 \%$ \\
\hline & & & (13) $7^{+}$Axle, M Trailers & 32 & $2.9 \%$ & 33 & 14.58 & $45.0 \%$ \\
\hline & & & (14) Unclassified/Other & 21 & $2.5 \%$ & 22 & 10.02 & $46.0 \%$ \\
\hline
\end{tabular}

--means estimate of AADT $(i)$ was at or near zero. 
Table 35. (continued)

\begin{tabular}{|c|c|c|c|c|c|c|c|c|}
\hline \multirow[b]{2}{*}{ Group } & \multirow[b]{2}{*}{ Site } & \multirow[b]{2}{*}{$\begin{array}{l}\text { Number } \\
\text { of Days }\end{array}$} & \multirow[b]{2}{*}{ Vehicle Class } & \multicolumn{2}{|c|}{ Original Estimates } & \multicolumn{3}{|c|}{$\begin{array}{c}\text { Simulated Estimates } \\
\text { (Factors do not contain information from site } \\
\text { being estimated.) }\end{array}$} \\
\hline & & & & \begin{tabular}{|c|} 
Estimated \\
AADT(i) \\
\end{tabular} & $\begin{array}{l}\text { Estimated } \\
\text { Precision }\end{array}$ & $\begin{array}{c}\text { Estimated } \\
\text { AADT(i) }\end{array}$ & $\begin{array}{c}\text { Square Root } \\
\text { of MSE }\end{array}$ & $\begin{array}{l}\text { Estimated } \\
\text { Precision }\end{array}$ \\
\hline \multirow[t]{12}{*}{2} & $\mathrm{P} 17$ & 334 & (3) Other 2 Axle, 4 Tire, S Unit & 5 & $3.5 \%$ & 5 & 3.71 & $70.0 \%$ \\
\hline & & & (4) Buses & - & -- & -- & - & -- \\
\hline & & & (5) 2 Axle, 6 Tire, $S$ Unit & 46 & $2.0 \%$ & 47 & 14.46 & $31.0 \%$ \\
\hline & & & (6) 3 Axle, S Unit & 10 & $4.2 \%$ & 13 & 11.49 & $90.0 \%$ \\
\hline & & & (7) $4^{+}$Axle, S Unit & - & -- & 2 & 18.33 & $881.0 \%$ \\
\hline & & & (8) 4- Axle, S Trailer & 12 & $3.2 \%$ & 13 & 7.58 & $56.0 \%$ \\
\hline & & & (9) 5 Axle, S Trailer & 185 & $2.1 \%$ & 205 & 82.13 & $40.0 \%$ \\
\hline & & & (10) $6^{+}$Axle, S Trailer & 30 & $3.3 \%$ & 36 & 21.58 & $60.0 \%$ \\
\hline & & & (11) 5-Axle, M Trailers & 16 & $2.4 \%$ & 17 & 8.40 & $49.0 \%$ \\
\hline & & & (12) 6 Axle, M Trailers & 30 & $4.8 \%$ & 30 & 26.53 & $88.0 \%$ \\
\hline & & & (13) $7^{+}$Axle, M Trailers & 85 & $2.7 \%$ & 95 & 40.91 & $43.0 \%$ \\
\hline & & & (14) Unclassified/Other & 4 & $3.4 \%$ & 5 & 2.74 & $60.0 \%$ \\
\hline \multirow[t]{12}{*}{3} & P29 & 364 & (3) Other 2 Axle, 4 Tire, S Unit & 31 & $4.2 \%$ & 35 & 30.21 & $87.0 \%$ \\
\hline & & & (4) Buses & 26 & $3.9 \%$ & 29 & 25.16 & $86.0 \%$ \\
\hline & & & (5) 2 Axle, 6 Tire, S Unit & 1,198 & $1.8 \%$ & 1,216 & 327.42 & $27.0 \%$ \\
\hline & & & (6) 3 Axle, S Unit & 268 & $2.9 \%$ & 263 & 123.31 & $47.0 \%$ \\
\hline & & & (7) $4^{+}$Axle, S Unit & 15 & $7.0 \%$ & 27 & 82.58 & $302.0 \%$ \\
\hline & & & (8) $4^{-}$Axle, S Trailer & 317 & $3.0 \%$ & 346 & 228.94 & $66.0 \%$ \\
\hline & & & (9) 5 Axle, S Trailer & 1,485 & $2.2 \%$ & 1,513 & 365.31 & $24.0 \%$ \\
\hline & & & (10) $6^{+}$Axle, $S$ Trailer & 146 & $3.4 \%$ & 152 & 88.84 & $58.0 \%$ \\
\hline & & & (11) 5 Axle, M Trailers & 71 & $4.2 \%$ & 82 & 75.39 & $92.0 \%$ \\
\hline & & & (12) 6 Axle, M Trailers & 114 & $2.9 \%$ & 127 & 94.64 & $75.0 \%$ \\
\hline & & & (13) $7^{+}$Axle, $M$ Trailers & 414 & $3.1 \%$ & 420 & 233.78 & $56.0 \%$ \\
\hline & & & (14) Unclassified/Other & 95 & $4.0 \%$ & 102 & 82.92 & $81.0 \%$ \\
\hline
\end{tabular}

--means estimate of $\mathrm{AADT}(i)$ was at or near zero. 
Table 35. (continued)

\begin{tabular}{|c|c|c|c|c|c|c|c|c|}
\hline \multirow[b]{2}{*}{ Group } & \multirow[b]{2}{*}{ Site } & \multirow[b]{2}{*}{$\begin{array}{l}\text { Number } \\
\text { of Days }\end{array}$} & \multirow[b]{2}{*}{ Vehicle Class } & \multicolumn{2}{|c|}{ Original Estimates } & \multicolumn{3}{|c|}{$\begin{array}{c}\text { Simulated Estimates } \\
\text { (Factors do not contain information from site } \\
\text { being estimated.) }\end{array}$} \\
\hline & & & & $\begin{array}{l}\text { Estimated } \\
\text { AADT(i) }\end{array}$ & $\begin{array}{l}\text { Estimated } \\
\text { Precision }\end{array}$ & $\begin{array}{l}\text { Estimated } \\
\text { AADT(i) }\end{array}$ & $\begin{array}{c}\text { Square Root } \\
\text { of MSE }\end{array}$ & $\begin{array}{l}\text { Estimated } \\
\text { Precision }\end{array}$ \\
\hline \multirow[t]{12}{*}{3} & $\mathrm{P} 3 \mathrm{~N}$ & 365 & (3) Other 2 Axle, 4 Tire, S Unit & 16 & $2.8 \%$ & 17 & 8.76 & $50.0 \%$ \\
\hline & & & (4) Buses & 85 & $1.9 \%$ & 93 & 43.58 & $47.0 \%$ \\
\hline & & & (5) 2 Axle, 6 Tire, S Unit & 1,270 & $1.5 \%$ & 1,295 & 287.35 & $22.0 \%$ \\
\hline & & & (6) 3 Axle, S Unit & 145 & $2.4 \%$ & 155 & 49.62 & $32.0 \%$ \\
\hline & & & (7) $4^{+}$Axle, $S$ Unit & 40 & $6.0 \%$ & 118 & 947.93 & $802.0 \%$ \\
\hline & & & (8) $4^{-}$Axle, S Trailer & 220 & $2.5 \%$ & 219 & 83.79 & $38.0 \%$ \\
\hline & & & (9) 5 Axle, S Trailer & 932 & $2.1 \%$ & 921 & 194.88 & $21.0 \%$ \\
\hline & & & (10) $6^{+}$Axle, S Trailer & 141 & $2.7 \%$ & 138 & 44.36 & $32.0 \%$ \\
\hline & & & (11) $5^{-}$Axle, $M$ Trailers & 55 & $2.6 \%$ & 56 & 24.77 & $45.0 \%$ \\
\hline & & & (12) 6 Axle, M Trailers & 48 & $2.5 \%$ & 47 & 15.76 & $33.0 \%$ \\
\hline & & & (13) $7^{+}$Axle, M Trailers & 184 & $2.0 \%$ & 217 & 105.11 & $48.0 \%$ \\
\hline & & & (14) Unclassified/Other & 129 & $3.0 \%$ & 140 & 79.74 & $57.0 \%$ \\
\hline \multirow[t]{12}{*}{3} & P5S & 362 & (3) Other 2 Axle, 4 Tire, S Unit & 9 & $2.6 \%$ & 12 & 9.24 & $80.0 \%$ \\
\hline & & & (4) Buses & 40 & $1.5 \%$ & 47 & 18.06 & $38.0 \%$ \\
\hline & & & (5) 2 Axle, 6 Tire, S Unit & 903 & $1.5 \%$ & 929 & 162.83 & $18.0 \%$ \\
\hline & & & (6) 3 Axle, S Unit & 162 & $3.7 \%$ & 181 & 124.18 & $69.0 \%$ \\
\hline & & & (7) $4^{+}$Axle, S Unit & 12 & $5.7 \%$ & 24 & 49.16 & $201.0 \%$ \\
\hline & & & (8) $4^{-}$Axle, S Trailer & 189 & $2.0 \%$ & 234 & 104.78 & $45.0 \%$ \\
\hline & & & (9) 5 Axle, S Trailer & 1,115 & $2.1 \%$ & 1,161 & 237.66 & $20.0 \%$ \\
\hline & & & (10) $6^{+}$Axle, S Trailer & 137 & $2.4 \%$ & 159 & 55.04 & $35.0 \%$ \\
\hline & & & (11) 5 Axle, M Trailers & 120 & $1.9 \%$ & 142 & 60.60 & $43.0 \%$ \\
\hline & & & (12) 6 Axle; $M$ Trailers & 114 & $2.0 \%$ & 125 & 37.29 & $30.0 \%$ \\
\hline & & & (13) $7^{+}$Axle, M Trailers & 189 & $2.8 \%$ & 197 & 58.30 & $30.0 \%$ \\
\hline & & & (14) Unclassified/Other & 113 & $1.9 \%$ & 128 & 60.39 & $47.0 \%$ \\
\hline
\end{tabular}


Table 35. (continued)

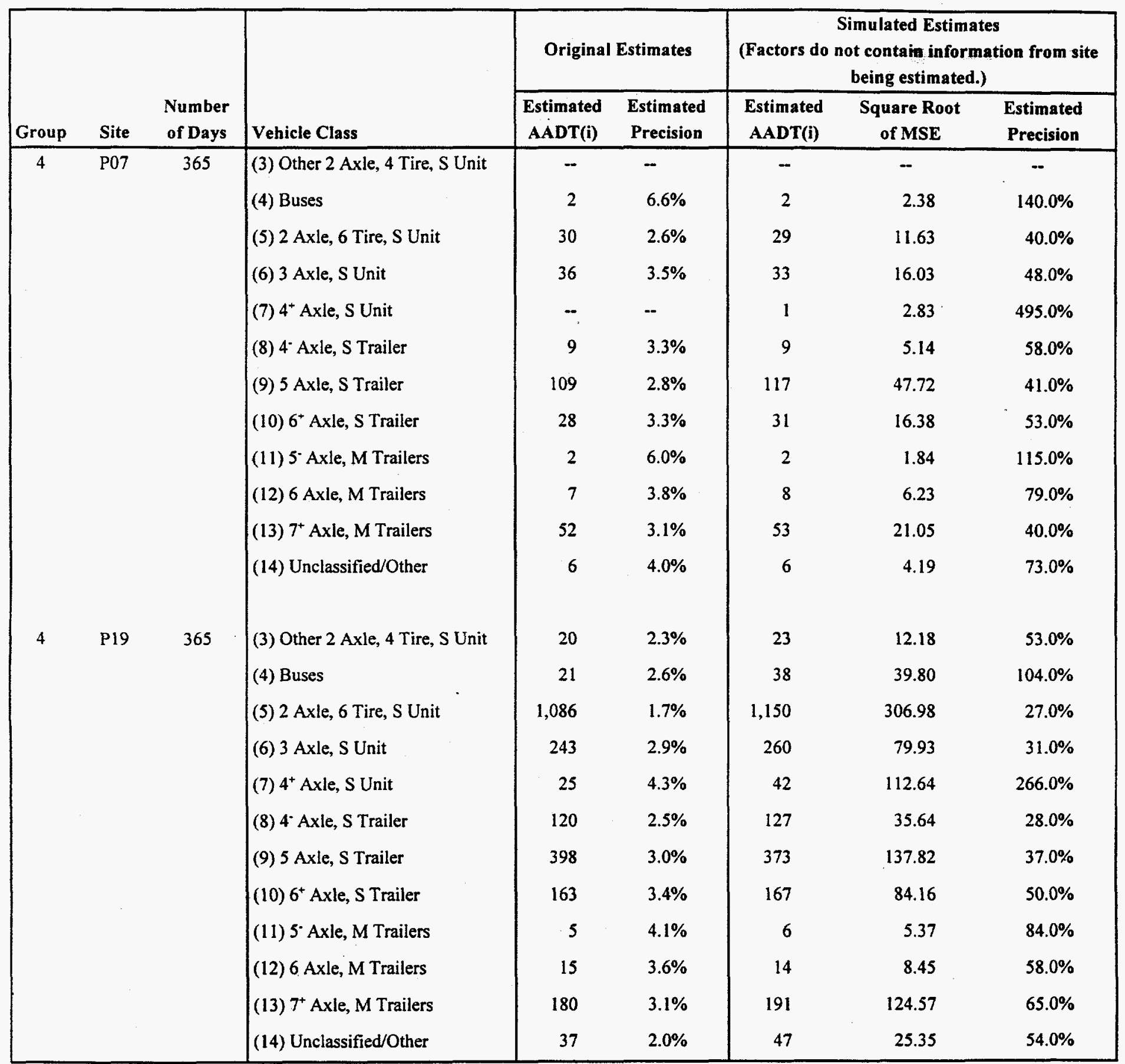

--means estimate of AADT( $i)$ was at or near zero. 
Table 35. (continued)

\begin{tabular}{|c|c|c|c|c|c|c|c|c|}
\hline \multirow[b]{2}{*}{ Group } & \multirow[b]{2}{*}{ Site } & \multirow[b]{2}{*}{$\begin{array}{l}\text { Number } \\
\text { of Days }\end{array}$} & \multirow[b]{2}{*}{ Vehicle Class } & \multicolumn{2}{|c|}{ Original Estimates } & \multicolumn{3}{|c|}{$\begin{array}{c}\text { Simulated Estimates } \\
\text { (Factors do not contain information from site } \\
\text { being estimated.) }\end{array}$} \\
\hline & & & & $\begin{array}{c}\text { Estimated } \\
\text { AADT(i) }\end{array}$ & $\begin{array}{c}\text { Estimated } \\
\text { Precision }\end{array}$ & $\begin{array}{c}\text { Estimated } \\
\text { AADT(i) }\end{array}$ & $\begin{array}{c}\text { Square Root } \\
\text { of MSE }\end{array}$ & $\begin{array}{c}\text { Estimated } \\
\text { Precision }\end{array}$ \\
\hline \multirow[t]{12}{*}{4} & $\mathrm{P} 20$ & 288 & (3) Other 2 Axle, 4 Tire, S Unit & 52 & $3.1 \%$ & 51 & 21.00 & $41.0 \%$ \\
\hline & & & (4) Buses & 18 & $3.3 \%$ & 32 & 29.98 & $93.0 \%$ \\
\hline & & & (5) 2 Axle, 6 Tire, S Unit & 1,231 & $1.5 \%$ & 1,368 & 445.23 & $33.0 \%$ \\
\hline & & & (6) 3 Axle, S Unit & 244 & $3.3 \%$ & 281 & 119.54 & $43.0 \%$ \\
\hline & & & (7) $4^{+}$Axle, S Unit & 15 & $6.4 \%$ & 44 & 307.22 & $696.0 \%$ \\
\hline & & & (8) $4^{\circ}$ Axle, S Trailer & 123 & $2.7 \%$ & 145 & 75.79 & $52.0 \%$ \\
\hline & & & (9) 5 Axle, $S$ Trailer & 832 & $2.7 \%$ & 1,036 & 556.23 & $54.0 \%$ \\
\hline & & & (10) $6^{+}$Axle, S Trailer & 207 & $4.3 \%$ & 233 & 126.28 & $54.0 \%$ \\
\hline & & & (11) $5^{\circ}$ Axle, $M$ Trailers & 16 & $2.5 \%$ & 25 & 19.75 & $78.0 \%$ \\
\hline & & & (12) 6 Axle, M Trailers & 71 & $2.5 \%$ & 101 & 69.98 & $69.0 \%$ \\
\hline & & & (13) $7^{+}$Axle, M Trailers & 258 & $3.6 \%$ & 288 & 136.32 & $47.0 \%$ \\
\hline & & & (14) Unclassified/Other & 104 & $2.2 \%$ & 132 & 73.02 & $55.0 \%$ \\
\hline
\end{tabular}

-means estimate of AADT $(i)$ was at or near zero. 
Table 36. Precision of Original and Simulated ESALs by Grouped Vehicle Classes For Washington's Weigh-In-Motion Sites

\begin{tabular}{|c|c|c|c|c|c|c|c|c|}
\hline \multirow[b]{2}{*}{ Group } & \multirow[b]{2}{*}{ Site } & \multirow[b]{2}{*}{$\begin{array}{l}\text { Number } \\
\text { of Days }\end{array}$} & \multirow[b]{2}{*}{ Grouped Vehicle Class } & \multicolumn{2}{|c|}{ Original Estimates } & \multicolumn{3}{|c|}{$\begin{array}{c}\text { Simulated Estimates } \\
\text { (Factors do not contain information from site } \\
\text { being estimated.) }\end{array}$} \\
\hline & & & & $\begin{array}{l}\text { Estimated } \\
\text { ESAL(Gi) }\end{array}$ & $\begin{array}{l}\text { Estimated } \\
\text { Precision }\end{array}$ & $\begin{array}{l}\text { Estimated } \\
\text { ESAL(Gi) }\end{array}$ & $\begin{array}{c}\text { Square Root } \\
\text { of MSE }\end{array}$ & $\begin{array}{l}\text { Estimated } \\
\text { Precision }\end{array}$ \\
\hline \multirow[t]{6}{*}{2} & P03 & 331 & G1 Passenger Vehicles & 0.00776 & $5.5 \%$ & 0.01042 & 0.0153 & $146.4 \%$ \\
\hline & & & G2 Single-Unit Trucks & 1.11291 & $3.2 \%$ & 1.57475 & 2.1940 & $139.3 \%$ \\
\hline & & & G3 Single-Trailer Trucks & 2.46255 & $2.0 \%$ & 2.54536 & 0.7711 & $30.3 \%$ \\
\hline & & & G4 Multi-Trailer Trucks & 2.19869 & $2.0 \%$ & 2.34148 & 0.9338 & $39.9 \%$ \\
\hline & & & G5 Very Large Trucks & 1.12415 & $2.0 \%$ & 1.21982 & 0.4579 & $37.5 \%$ \\
\hline & & & G6 Unknown Vehicles & 0.54097 & $4.2 \%$ & 0.82244 & 0.8950 & $108.8 \%$ \\
\hline \multirow[t]{6}{*}{2} & P05 & 346 & G1 Passenger Vehicles & 0.00711 & $7.5 \%$ & 0.00857 & 0.0102 & $118.5 \%$ \\
\hline & & & G2 Single-Unit Trucks & 1.42218 & $4.9 \%$ & 3.37957 & 20.7556 & $614.1 \%$ \\
\hline & & & G3 Single-Trailer Trucks & 3.49431 & $2.7 \%$ & 3.57936 & 1.3996 & $39.1 \%$ \\
\hline & & & G4 Multi-Trailer Trucks & 2.54665 & $2.8 \%$ & 2.60830 & 1.3257 & $50.8 \%$ \\
\hline & & & G5 Very Large Trucks & 1.68011 & $2.8 \%$ & 1.74882 & 0.8893 & $50.9 \%$ \\
\hline & & & G6 Unknown Vehicles & 0.71534 & $5.2 \%$ & 1.08816 & 1.1556 & $106.2 \%$ \\
\hline \multirow[t]{6}{*}{2} & P17 & 334 & G1 Passenger Vehicles & 0.00846 & $11.6 \%$ & 0.01137 & 0.0427 & $375.3 \%$ \\
\hline & & & G2 Single-Unit Trucks & 0.61247 & $5.8 \%$ & 0.69815 & 0.8596 & $123.1 \%$ \\
\hline & & & G3 Single-Trailer Trucks & 3.49826 & $2.0 \%$ & 3.66065 & 1.2035 & $32.9 \%$ \\
\hline & & & G4 Muiti-Trailer Trucks & 3.72136 & $1.7 \%$ & 3.89418 & 1.4247 & $36.6 \%$ \\
\hline & & & G5 Very Large Trucks & 1.33664 & $1.6 \%$ & 1.46540 & 0.5242 & $35.8 \%$ \\
\hline & & & G6 Unknown Vehicles & 0.47389 & $13.0 \%$ & 0.59070 & 1.3783 & $233.3 \%$ \\
\hline \multirow[t]{6}{*}{3} & $\mathrm{P} 29$ & 364 & G1 Passenger Vehicles & 0.11783 & $17.9 \%$ & 0.12667 & 0.4572 & $360.9 \%$ \\
\hline & & & G2 Single-Unit Trucks & 2.28722 & $2.5 \%$ & 2.36025 & 1.2103 & $51.3 \%$ \\
\hline & & & G3 Single-Trailer Trucks & 3.07931 & $1.3 \%$ & 3.05715 & 0.6445 & $21.1 \%$ \\
\hline & & & G4 Multi-Trailer Trucks & 3.06553 & $1.5 \%$ & 3.05917 & 0.7299 & $23.9 \%$ \\
\hline & & & G5 Very Large Trucks & 1.55673 & $1.6 \%$ & 1.58010 & 0.4615 & $29.2 \%$ \\
\hline & & & G6 Unknown Vehicles & 0.54108 & $5.7 \%$ & 1.00086 & 2.1043 & $210.2 \%$ \\
\hline \multirow[t]{6}{*}{3} & P3N & 365 & G1 Passenger Vehicles & 0.01584 & $5.8 \%$ & 0.08419 & 0.1224 & $145.4 \%$ \\
\hline & & & G2 Single-Unit Trucks & 1.98667 & $2.0 \%$ & 2.05632 & 0.6258 & $30.4 \%$ \\
\hline & & & G3 Single-Trailer Trucks & 2.56789 & $1.3 \%$ & 2.56358 & 0.4854 & $18.9 \%$ \\
\hline & & & G4 Multi-Trailer Trucks & 2.21641 & $1.7 \%$ & 2.22774 & 0.6612 & $29.7 \%$ \\
\hline & & & G5 Very Large Trucks & 1.54463 & $1.5 \%$ & 1.58012 & 0.4017 & $25.4 \%$ \\
\hline & & & G6 Unknown Vehicles & 0.94208 & $6.3 \%$ & 1.26129 & 1.9036 & $150.9 \%$ \\
\hline
\end{tabular}


Table 36. (continued)

\begin{tabular}{|c|c|c|c|c|c|c|c|c|}
\hline \multirow[b]{2}{*}{ Group } & \multirow[b]{2}{*}{ Site } & \multirow[b]{2}{*}{$\begin{array}{l}\text { Number } \\
\text { of Days }\end{array}$} & \multirow[b]{2}{*}{ Grouped Vehicle Class } & \multicolumn{2}{|c|}{ Original Estimates } & \multicolumn{3}{|c|}{$\begin{array}{c}\text { Simulated Estimates } \\
\text { (Factors do not contain information from site } \\
\text { being estimated.) }\end{array}$} \\
\hline & & & & $\begin{array}{l}\text { Estimated } \\
\operatorname{ESAL}(\mathbf{G})\end{array}$ & $\begin{array}{c}\text { Estimated } \\
\text { Precision } \\
\end{array}$ & $\begin{array}{l}\text { Estimated } \\
\operatorname{ESAL}(\mathbf{G}) \\
\end{array}$ & $\begin{array}{c}\text { Square Root } \\
\text { of MSE } \\
\end{array}$ & $\begin{array}{c}\text { Estimated } \\
\text { Precision } \\
\end{array}$ \\
\hline \multirow[t]{6}{*}{3} & P5S & 362 & G1 Passenger Vehicles & 0.01347 & $4.0 \%$ & 0.06994 & 0.0949 & $135.7 \%$ \\
\hline & & & G2 Single-Unit Trucks & 2.90065 & $1.9 \%$ & 3.18204 & 1.3810 & $43.4 \%$ \\
\hline & & & G3 Single-Trailer Trucks & 3.59569 & $0.6 \%$ & 3.87116 & 1.0939 & $28.3 \%$ \\
\hline & & & G4 Multi-Trailer Trucks & 4.16916 & $0.8 \%$ & 4.48423 & 1.2702 & $28.3 \%$ \\
\hline & & & G5 Very Large Trucks & 2.11898 & $1.3 \%$ & 2.31569 & 0.8945 & $38.6 \%$ \\
\hline & & & G6 Unknown Vehicles & 0.97310 & $4.7 \%$ & 1.54597 & 2.0733 & $134.1 \%$ \\
\hline \multirow[t]{6}{*}{4} & $\mathrm{P} 07$ & 365 & Gl Passenger Vehicles & $\cdots$ & $\cdots$ & $\cdots$ & -- & - \\
\hline & & & G2 Single-Unit Trucks & 1.58737 & $4.0 \%$ & 1.64574 & 1.2088 & $73.4 \%$ \\
\hline & & & G3 Single-Trailer Trucks & 3.34056 & $1.7 \%$ & 3.51789 & 1.1436 & $32.5 \%$ \\
\hline & & & G4 Multi-Trailer Trucks & 2.60388 & $4.2 \%$ & 2.77120 & 2.3220 & $83.8 \%$ \\
\hline & & & G5 Very Large Trucks & 1.61962 & $1.3 \%$ & 1.70562 & 0.4533 & $26.6 \%$ \\
\hline & & & G6 Unknown Vehicles & 1.27191 & $6.8 \%$ & 1.94420 & 6.1319 & $315.4 \%$ \\
\hline \multirow[t]{6}{*}{4} & P19 & 365 & G1 Passenger Vehicles & 0.01110 & $2.8 \%$ & 0.01146 & 0.0058 & $50.7 \%$ \\
\hline & & & G2 Single-Unit Trucks & 2.68042 & $2.0 \%$ & 2.82533 & 1.0342 & $36.6 \%$ \\
\hline & & & G3 Single-Trailer Trucks & 2.17607 & $1.6 \%$ & 2.15623 & 0.4653 & $21.6 \%$ \\
\hline & & & G4 Multi-Trailer Trucks & 2.15544 & $2.3 \%$ & 2.51769 & 1.8746 & $74.5 \%$ \\
\hline & & & G5 Very Large Trucks & 1.62796 & $1.4 \%$ & 1.60996 & 0.3114 & $19.3 \%$ \\
\hline & & & G6 Unknown Vehicles & 0.43418 & $4.0 \%$ & 0.47889 & 0.3083 & $64.4 \%$ \\
\hline \multirow[t]{6}{*}{4} & $\mathrm{P} 20$ & 288 & Gl Passenger Vehicles & 0.00987 & $2.8 \%$ & 0.01029 & 0.0043 & $42.1 \%$ \\
\hline & & & G2 Single-Unit Trucks & 2.53717 & $2.3 \%$ & 2.78393 & 1.2998 & $46.7 \%$ \\
\hline & & & G3 Single-Trailer Trucks & 2.79177 & $1.3 \%$ & 2.86504 & 0.6115 & $21.3 \%$ \\
\hline & & & G4 Multi-Trailer Trucks & 2.47074 & $1.9 \%$ & 2.98795 & 1.9049 & $63.8 \%$ \\
\hline & & & G5 Very Large Trucks & 1.85853 & $1.4 \%$ & 1.86646 & 0.3259 & $17.5 \%$ \\
\hline & & & G6 Unknown Vehicles & 0.35285 & $5.4 \%$ & 0.63348 & 1.6695 & $263.6 \%$ \\
\hline
\end{tabular}


Table 37. Range of Coefficients of Variation (CV) and Estimated Precision of the Original and the Simulated ESAL Estimates For 3 Washington's Weigh-In-Motion Sites

\begin{tabular}{|c|c|c|c|c|}
\hline \multirow[b]{2}{*}{ Site } & \multirow{2}{*}{ Grouped Vehicle Class } & \multirow{2}{*}{$\begin{array}{l}\text { Range of CVs for } \\
\text { Daily ESAL per } \\
\text { Vehicle }(\%)\end{array}$} & \multicolumn{2}{|c|}{ Estimated Precision } \\
\hline & & & $\begin{array}{l}\text { Original ESAL } \\
\text { Estimate } \\
(\mathbf{G i})\end{array}$ & $\begin{array}{c}\text { Simulated ESAL } \\
\text { Estimate } \\
\text { (Gi) }\end{array}$ \\
\hline \multirow[t]{6}{*}{ P05 } & Gl Passenger Vehicles & $139.1 \%$ & $7.5 \%$ & $118.5 \%$ \\
\hline & G2 Single-Unit Trucks & $76.4-294.3 \%$ & $4.9 \%$ & $614.1 \%$ \\
\hline & G3 Single-Trailer Trucks & $38.9-75.1 \%$ & $2.7 \%$ & $39.1 \%$ \\
\hline & G4 Multi-Trailer Trucks & $57.3-75.3 \%$ & $2.8 \%$ & $50.8 \%$ \\
\hline & G5 Very Large Trucks & $52.9 \%$ & $2.8 \%$ & $50.9 \%$ \\
\hline & G6 Unknown Vehicles & $97.3 \%$ & $5.2 \%$ & $106.2 \%$ \\
\hline \multirow[t]{6}{*}{ P17 } & G1 Passenger Vehicles & $211.8 \%$ & $11.6 \%$ & $375.3 \%$ \\
\hline & G2 Single-Unit Trucks & $88.3-397.0 \%$ & $5.8 \%$ & $123.1 \%$ \\
\hline & G3 Single-Trailer Trucks & $25.2-92.7 \%$ & $2.0 \%$ & $32.9 \%$ \\
\hline & G4 Multi-Trailer Trucks & $33.1-43.9 \%$ & $1.7 \%$ & $36.6 \%$ \\
\hline & G5 Very Large Trucks & $29.2 \%$ & $1.6 \%$ & $35.8 \%$ \\
\hline & G6 Unknown Vehicles & $237.6 \%$ & $13.0 \%$ & $233.3 \%$ \\
\hline \multirow[t]{6}{*}{ P29 } & G1 Passenger Vehicles & $341.8 \%$ & $17.9 \%$ & $360.9 \%$ \\
\hline & G2 Single-Unit Trucks & $45.9-86.5 \%$ & $2.5 \%$ & $51.3 \%$ \\
\hline & G3 Single-Trailer Trucks & $27.1-50.3 \%$ & $1.3 \%$ & $21.1 \%$ \\
\hline & G4 Multi-Trailer Trucks & $32.7-37.7 \%$ & $1.5 \%$ & $23.9 \%$ \\
\hline & G5 Very Large Trucks & $30.4 \%$ & $1.6 \%$ & $29.2 \%$ \\
\hline & G6 Unknown Vehicles & $109.0 \%$ & $5.7 \%$ & $210.2 \%$ \\
\hline
\end{tabular}




\section{SUMMARY REMARKS \\ Precision of Short-term Monitored Data}

The original estimates of traffic characteristics (i.e., AADT, AADT by vehicle class, and daily ESAL per vehicle) by treating the sites as a continuously monitored sites are, on average, quite close to the simulated estimates treating the sites as short-term monitored sites. Based on the maximum ratio, the original AADT estimate and simulated AADT estimates at a given site are, on average, within $2 \%$ of each other.

The simulated estimates tend to be higher than the original estimates in almost all cases. This may suggest some (slight) positive bias in the simulated estimates.

Not surprisingly, the original estimates (continuous monitoring) appear to be more precise, on average, than the simulated estimates (short-term monitoring). This apparent decrease in the precision of the simulated estimates is, in part, very likely due to possible bias.

Similar empirical results are observed for classification data. The decrease in the precision of the simulated estimates typically occurs for vehicle classes that account for less than $1 \%$ of the daily traffic volume, suggesting that these less common vehicle classes be combined to achieve reliable AADT estimates.

The approach that is used to adjust short-term traffic count data produces acceptable ESAL estimates for short-term monitoring WIM sites only if the daily loading does not substantially vary. For vehicle classes in which the daily loading varies widely, a new approach needs to be developed to more accurately reflect the temporal variations.

In general, the methodology that uses factors from continuously monitored sites seems to work extremely well for producing estimates of total traffic volume for short-term monitored sites. However, its ability to produce estimates of vehicle classification counts for short-term monitored sites decreases for less common vehicle types, those accounting for less than $1 \%$ of daily traffic volume. One option to overcome this problem is to combine these less common vehicle classes. Applying this factoring method to short-term WIM data is inappropriate. A new procedure needs to be developed. 


\section{RECOMMENDATIONS FOR FUTURE TRAFFIC DATA COLLECTION PROGRAM}

Based on findings from this study, recommendations for future traffic data collection efforts can be summarized into five major points:

\section{- Support research to determine to what extent sampling can efficiently assist continuous traffic monitoring to characterize traffic patterns.}

Continuous monitoring data are plagued by missing data. In fact, a continuous traffic monitoring program that would provide 365 days of complete data seems to be extremely rare. We conducted simulation studies to assess the impact of randomly missing data - on traffic estimates. Preliminary results suggest that: (1) randomly missing data have little effect on traffic estimates, and (2) the loss in reliability in AADT estimates, due to missing data, may very well be tolerable, even though the reliability decreases as missing data increase. Similarly, the amount of missing data had negligible effect on the estimated coefficients of variation for the sites considered.

Our analysis of randomly missing days shows that reliable results can be obtained for AADT (AADT by vehicle class, average daily ESAL and weight per vehicle), even with high levels of randomly missing data. This finding is based on theoretical results in probability sampling theory. Even if we have randomly consecutive missing days (clusters), reliable results for AADT can still be obtained, a conclusion that is also based on probability sampling theory.

These findings suggest that rather than processing the entire continuous traffic data on a continuous basis, it might be feasible to sample this continuous data stream and, perhaps, to update traffic estimates on a periodic basis. Sampling strategies (based on "days" or "clusters of days") can be developed to provide estimates, essentially as accurate and reliable as one would obtain from " $100 \%$ data from continuously monitored sites."

The contributions to the variability in traffic data vary by the day of the week, weekends versus weekdays, the month of the year, and holiday periods versus nonholiday periods. In fact, the greater contributors to traffic count variability are the weekend days rather than the weekdays, the winter months rather than the summer months, and the "all holiday period" days rather than the "non-holiday period" days. 
Daily contributors to the variability in daily traffic classification data differ among vehicle classes. These results provide preliminary guidance for one to consider a larger role of sampling in traffic monitoring programs. It suggests that one should sample more where there is greater variability.

\section{2) Conduct research to investigate the advantages and disadvantages of combining} certain vehicle classes.

Four results prompt this recommendation. First, high coefficients of variation (i.e. variability) associated with AADT tend to occur with vehicle classes that have extremely low mean daily traffic volumes (Figure 2). To lower these high coefficients of variation, one can consider reducing the number of vehicle classes by combining less common vehicle classes. This reduction may also lead to better quality classification data in cases where one class is difficult to be distinguished from another when using current monitoring classification equipment.

Second, the occurrence of a multi-trailer vehicle on any day is rare. At almost every one of the eight classification sites, the level of unclassified/other vehicles is quite high relative to what is captured in other vehicle classes. The large percentage of vehicles being unclassified (Class 14) may signal some concern for the reported counts in the other classes. It may also signal the need to consider decreasing the number of classes until technology can be improved to distinguish among similar types of vehicles with greater certainty. This decrease in the number of vehicle classes may also lead to a significant decrease in the level of unclassified vehicles. One such grouping is proposed in Table 19.

Third, for vehicle classes with low mean daily traffic volumes, traffic estimates calculated using five different approaches, ranging from simple to complex, are rather different. On the other hand, for vehicle classes with high mean daily traffic volumes, the five approaches produced estimates no more than 5 percent difference from each other. These results may be additional motivation for combining some vehicle classes, especially among classes with low mean daily traffic columns.

Fourth, the estimates of traffic characteristics based on continuously monitoring data appear to be more precise, on average, than the simulated estimates in which the site is treated as a short-term monitored site. This decrease in precision typically occurs 
for vehicle classes that account for less than $1 \%$ of daily traffic volume, suggesting that these less common vehicle classes should be combined in order to achieve reliable AADT estimates.

We are aware that this recommendation for research is based on data from only a few sites in only two states.

\section{(3) Monitor traffic in both directions.}

The analysis of count and classification data by direction of travel shows that traffic differs significantly by direction. This finding is significant in practice because it confirms the need to monitor traffic volume and classification data in both directions instead of just monitoring in one direction and multiplying the result by two. (We are aware that most states already know this, and it is recognized in all relevant prior documents on traffic monitoring.)

This analysis was not performed on WIM data because there are no directional WIM data.

\section{(4) Monitor missing data.}

Monitor missing data and use graphics and exploring data analysis methods to easily reveal systematic patterns of missing data. Systematic patterns of missing data signal potential equipment problems, thereby providing valuable information for maintenance scheduling. Furthermore, patterns of missing data help guide users to avoid inappropriate analysis and misinterpretation of the data.

\section{( Continue data analysis program of traffic monitoring data.}

For sure, any data analysis of traffic monitoring data should be in support of clearly stated objectives. We have provided a variety of elementary analyses using data from Florida and Washington states. Details are found in [2], [3], [4], [7], [16]. To better aid the development of highway strategies with more accurate and timely traffic characteristics, we propose that the traffic data analysis programs in each state include, at a minimum:: 
(i) data editing methods (such as the approaches used by Florida Department of Transportation, [11] and [16],

(ii) tracking of missing data at each continuously monitored site using graphics,

(iii) development of adjustment factors for AADT estimates from short-term, monitored sites as discussed in [1] and illustrated in [7].

(iv) computation of total volume averages by day of week and month of year at volume sites,

(v) computation of volume and percentages of each vehicle class by day of week and month of year at each classification site,

(vi) computation of average weight and ESAL per day and month at each WIM site,

(vii) computation of CVs for publication with AADTs for continuously monitored sites, and

(viii) computation of AADT for continuously monitored sites using simple averages, including in the presence of missing data that do not show a systematic missing pattern. 


\section{REFERENCES}

1. Traffic Monitoring Guide, U. S. DOT, (Third Edition, February 1995), FHWA-PL-95-031. Federal Highway Administration, Washington, D.C.

2. Variability in Continuous Traffic Monitoring Data Task II Report: Pilot Methodology Development and Estimates of Variability from Continuous Traffic Count Data, (Oct. 1995), unpublished report of the Center for Transportation Analysis, Oak Ridge National Laboratory, Oak Ridge, Tennessee 37831.

3. Variability in Continuous Traffic Monitoring Data Task V Report: Pilot Methodology Development and Estimates of Variability from Continuous Traffic Classification Count Data, (January 1996), unpublished report of the Center for Transportation Analysis, Oak Ridge National Laboratory, Oak Ridge, Tennessee 37831.

4. Variability in Continuous Traffic Monitoring Data Task VIII Report: Pilot Methodology Development and Estimates of Variability from Continuous Traffic Weigh-In-Motion Data, (April 1996), unpublished report of the Center for Transportation Analysis, Oak Ridge National Laboratory, Oak Ridge, Tennessee 37831.

5. AASHTO Guidelines for Traffic Data Programs (1992), American Association of State Highway and Transportation Officials, Washington, D.C.

6. Tsao, H. and Wright, T. (1983). "On the Maximum Ratio: A Tool for Assisting Inaccuracy Assessment," The American Statistician, 37 339-342.

7. Variability in Continuous Traffic Monitoring Data Tasks IV, VII, and X Report: Precision in Estimates of AADT and AADT by Vehicle Class for Short-Term Traffic Monitoring Sites and Its Relation to Variability in Estimates for Continuously Monitored Sites, (November 1996), unpublished report of the Center for Transportation Analysis, Oak Ridge National Laboratory, Oak Ridge, Tennessee 37831.

8. FDOT Traffic Monitoring System for the Highways (TMS/H) - Work Plan (December 1994), Transportation Statistics Office, Florida Department of Transportation, Tallahassee, Florida.

9. Reel, R. L. "Automated Editing of Traffic Data in Florida," Proceedings of the 1994 National Traffic Data Acquisition Conference, Vol. 2, pp. 143-164, Rocky Hill, Connecticut

10. Florida DOT Design Traffic Handbook - Draft (February 6, 1995), Florida Department of Transportation, Tallahassee, Florida.

11. End of Year Processing Procedures: Program Descriptions (Florida) (1994), Farradyne Systems, Inc., Rockville, Maryland. 
12. Standardization of Count and Classification Equipment Setup and Configuration Progress Final Report (Florida) (January 18, 1995), by Farradyne Systems, Inc., Rockville, Maryland.

13. Washington State Traffic Monitoring System for Highways (TMS/H) Work Plan (December 27, 1994), Washington State Department of Transportation, Olympia, Washington.

14. Key Facts: A Summary of Useful Transportation Data (January 1995), Washington State Department of Transportation, Olympia, Washington.

15. IRD WIM System - Software Users' Manual: Release 7.4.3 (August 17, 1993), Washington State Department of Transportation, Olympia, Washington.

16. Variability in Florida Continuous Traffic Monitoring Data (Working Draft Paper - Task 1 Report) (May 31, 1995), unpublished report of the Center for Transportation Analysis, Oak Ridge, Tennessee. 